\title{
SELEÇÃO DE GENES CODIFICADORES DE PHA SINTASES PARA A CONSTRUÇÃO DE RECOMBINANTES EM Burkholderia sacchari E Pseudomonas sp E AVALIAÇÃO DA PRODUÇÃO DE POLIHIDROXIALCANOATOS COM DIFERENTES COMPOSIÇÕES MONOMERICAS
}

Dissertação apresentada ao Departamento de Microbiologia do Instituto de Ciências Biomédicas da Universidade São Paulo, para obtenção do Título de Mestre em Ciências. 
THANDARA GARCIA RAVELLI

SELEÇÃO DE GENES CODIFICADORES DE PHA SINTASES

PARA A CONSTRUÇÃO DE RECOMBINANTES

EM Burkholderia sacchari E Pseudomonas sp E AVALIAÇÃO DA

PRODUÇÃO DE POLIHIDROXIALCANOATOS COM

DIFERENTES COMPOSIÇÕES MONOMERICAS

Dissertação apresentada ao Departamento de Microbiologia do Instituto de Ciências Biomédicas da Universidade São Paulo, para obtenção do Título de Mestre em Ciências.

Área de concentração: Microbiologia

Orientadora: Prof ${ }^{a}$ Dr $^{\mathrm{a}}$ Luiziana Ferreira da Silva

Versão corrigida. A versão original eletrônica encontra-se disponível tanto na Biblioteca do ICB quanto na Biblioteca Digital de Teses e Dissertações da USP (BDTD) 
DADOS DE CATALOGAÇÃO NA PUBLICAÇÃO (CIP)

Serviço de Biblioteca e Informação Biomédica do

Instituto de Ciências Biomédicas da Universidade de São Paulo

() reprodução total

Ravelli, Thandara Garcia.

Seleção de genes codificadores de PHA sintases para a construção de recombinantes em Burkholderia sacchari e Pseudomonas sp. e avaliação da produção de polihidroxialcanoatos com diferentes composições monoméricas / Thandara Garcia Ravelli. -- São Paulo, 2014.

Orientador: Profa. Dra. Luiziana Ferreira da Silva.

Dissertação (Mestrado) - Universidade de São Paulo. Instituto de Ciências Biomédicas. Departamento de Microbiologia. Área de concentração: Microbiologia. Linha de pesquisa: Biopolímeros.

Versão do título para o inglês: Selection of PHA synthases coding genes for the construction of recombinant Burkholderia sacchari and Pseudomonas sp. and evaluation of polyhydroxyalkanoate production with different monomer compositions.

1. PHA 2. PHA sintase 3. Burkholderia 4. Pseudomonas 5. Metagenômica I. Silva, Profa. Dra. Luiziana Ferreira da II. Universidade de São Paulo. Instituto de Ciências Biomédicas. Programa de Pós-Graduação em Microbiologia III. Título. 
Candidato(a):

Título da Dissertação:

Orientador(a):
Thandara Garcia Ravelli.

Seleção de genes codificadores de PHA sintases para a construção de recombinantes em Burkholderia sacchari e Pseudomonas sp. e avaliação da produção de polihidroxialcanoatos com diferentes composições monoméricas.

A Comissão Julgadora dos trabalhos de Defesa da Dissertação de Mestrado, em sessão pública realizada a J... , considerou
( ) Aprovado(a)
( ) Reprovado(a)
Examinador(a): Assinatura:
Nome:
Instituição:
Examinador(a): Assinatura:
Nome:
Instituição:

Presidente: Assinatura:

Nome:

Instituição: 


\title{
CERTIFICADO DE ISENÇÃO
}

\author{
Certificamos que o Protocolo CEP-ICB N $527 / 12$
}

referente ao projeto intirulado: "Construcion de recombinantes portando genes selecionados numa biblioteca metagenomica e araliaçào da capacidade de acumulo de polímeros biodegradívers da familia dos polibidroxialcanoatos (PHA)" sob a responsabilidade de Thandara Garcia Ravelli, foi analisado na presente data pela CEUA - COMISSÃO DF ÉTKCA NO L'SO DH AnIMAis e pela CEPSH- COMISSÃo de ÉtTCA FM PEsqLisa COM SERES IUMANOS, tendo sido deliberado que o referido projeto não utilizara animais que estejam sob a égide da lei 11.794 de 8 de outubro de 2008. nem envolverá procedimentos regulados pela Resolução CONEP n'196 de 1996.

São Paulo, 1.3 de junho de 2012.

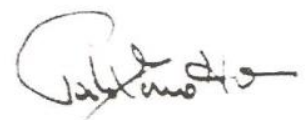

PR()E, DR. WOTHAI TAIARFSI)E LIMA

Coordenador da CEUA - ICB/USP
PRof. DR. PAOLO M.AZANOTTO Coordenador da CEPsh - ICB/USP

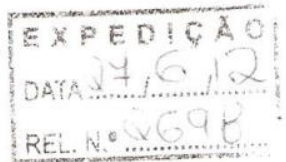


À minha família. 


\section{AGRADECIMENTOS}

Agradeço à Profa. Dra. Luiziana Ferreira da Silva pela orientação e pela oportunidade. Agradeço ao Prof. Dr. José Gregório Cabrera Gomez, também pela orientação, pelas sugestões e discussões.

Aos meus pais Rosana e Virgílio pela dedicação, apoio, carinho e incentivo e principalmente por me darem a oportunidade de conquistar meus objetivos. Aos meus irmãos Katherine e Fernando e ao meu namorado Márcio, por sempre me apoiarem e estarem ao meu lado nos momentos mais difíceis.

Agradeço aos técnicos do laboratório: Aelson Luis dos Santos e Alexandre Aparecido, pelo apoio. Aos amigos, principalmente Aline, Diana, Thati, Jhoanne e Edmar, que foram fundamentais e sempre me ajudaram no que precisei.

Agradeço ao prof Steinbüchel pela gentil doação de genes relevantes ao trabalho

Agradeço a Deus pela saúde e pela força.

E por fim, agradeço à Fundação de Amparo à Pesquisa do Estado de São Paulo pelo suporte financeiro. 
"Todo conhecimento é resposta a uma pergunta"

Gaston Bachelard 


\section{RESUMO}

RAVELLI, T. G. Seleção de genes codificadores de PHA sintases para a construção de recombinantes em Burkholderia sacchari e Pseudomonas sp e avaliação da produção de polihidroxialcanoatos com diferentes composições monoméricas. 2014. 109 f. Dissertação (Mestrado em Microbiologia) - Instituto de Ciências Biomédicas, Universidade São Paulo, São Paulo, 2014.

Polihidroxialcanoatos (PHA) são poliésteres acumulados por diversas bactérias a partir de fontes renováveis que despertam grande interesse industrial por serem termoplásticos biodegradáveis e biocompatíveis. A variabilidade da composição monomérica de PHA determina suas propriedades mecânicas e permite seu uso em diversas aplicações. Os PHA

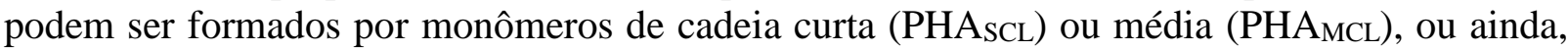
formar copolímeros (PHAsCL-co-PHAMCL) que têm propriedades intermediárias. Três .aspectos são determinantes para a produção de PHA: a fonte de carbono, as vias metabólicas bacterianas e a enzima PHA sintase. A enzima PHA sintase catalisa a polimerização de moléculas de $R$ hidroxiacil-CoA formando o biopolímero, sendo, assim, a enzima chave na biossíntese de PHA. São conhecidos quatro tipos de PHA sintases, de acordo com a especificidade pelo substrato e pela composição de peptídeos. Muitos estudos têm sido desenvolvidos buscando diferentes composições do polímero. Dessa forma, o objetivo deste trabalho foi à busca por genes codificadores desta enzima, construção e avaliação de recombinantes portando tais genes para buscar materiais com novas propriedades e aplicações. Inicialmente buscou-se novos genes de PHA sintase a partir de 390 clones de uma biblioteca metagenômica previamente detectados por PCR como positivos para algum tipo de PHA sintase. Posteriormente, duas novas fontes de PHA sintase foram buscadas: genes codificadores de PHA sintase III de Thiocapsa pfennigii e Allochromatium vinosum. Dos 390 clones, apenas 2 mostraram resultado positivo para PHA sintase de classe II através de reação de PCR e de sequenciamento, apresentando similaridade com genes conhecidos. Pelo fato de que as PHA sintases do tipo II já terem sido amplamente estudadas, ao contrário daquelas do tipo III, mais promissoras para este trabalho, genes codificadores foram buscados para testar sua inserção em hospedeiros capazes de acumular altas concentrações de PHA, mas afetados na sua PHA sintase nativa (Pseudomonas putida e Burkholderia sacchari), avaliando-se o tipo de PHA produzido Assim, recombinantes de Pseudomonas sp e B. sacchari foram construídos pela introdução de genes de $T$. pfennigii $\left(p h a E C_{T p}\right.$ ) e de $C$. vinosum ( $p h a E C_{C v}$ ) clonados em pBBR1-MCS2. A produção de PHA pelos recombinantes obtidos foi avaliada qualitativamente por testes de coloração com Sudan Black $\mathrm{B}$, indicaram resultados positivos apenas em Burkholderia sacchari abrigando o gene de $C$. vinosum sendo que para Pseudomonas putida abrigando phaEC $C_{C v}$ e phaEC $C_{T p}$ e Burkholderia sacchari phaEC $C_{T p}$ o resultado foi negativo. Quantitativamente, a produção de PHA foi avaliada com ensaios em frascos agitados, empregando-se glicose e ácidos graxos contendo de 3 a 9 carbonos. A expressão dos genes phaEC $C_{V}$ em B. sacchari $\mathrm{PHA}^{-}$foi bem sucedida, uma vez que os mesmos foram capazes de reestabelecer a produção de PHA na mutante. Utilizando glicose, tanto a linhagem selvagem como o recombinante de Burkholderia sacchari produziram um PHA composto de monômeros de 3-hidroxibutirato (3HB). A partir de hexanoato e glicose obteve-se um copolimero no qual foi possível aumentar a fração de $3 \mathrm{HHx}$ de $0,30 \mathrm{~mol} \%$ na linhagem selvagem para $1,85 \mathrm{~mol} \%$, na linhagem mutante. Pseudomonas putida abrigando phaEC $_{C v}$ produziu um PHA no qual foi observado um aumento na fração de $3 \mathrm{HHx}$ de 0 para 9,11 mol\% quando glicose foi fornecida como fonte de carbono. Essas linhagens poderão ser empregadas na produção de PHA com composição variada, controlando-se a incorporação de 
frações 3HHx o que deve refletir nas suas propriedades, ampliando suas possibilidades de aplicação.

Palavras-chave: PHA. Metagenômica. Pseudomonas. Burkholderia. PHA sintase. 


\begin{abstract}
RAVELLI, T. G. Selection of PHA synthases coding genes for the construction of recombinant Burkholderia sacchari and Pseudomonas sp and evaluation of polyhydroxyalkanoate production with different monomer compositions. 2014. 109 p. Masters thesis (Microbiology) - Instituto de Ciências Biomédicas, Universidade São Paulo, São Paulo, 2014.
\end{abstract}

Polyhydroxyalkanoates (PHA) are polyesters accumulated by several bacteria from renewable sources that arouse great industrial interest because they are biodegradable and biocompatible thermoplastic. The variability of the PHA monomer composition determines its mechanical properties and allows their use in many applications. The PHAs may be formed by short-chain

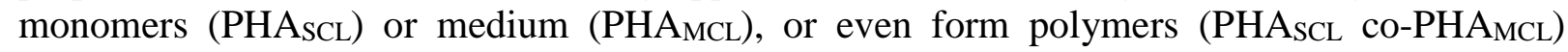
having intermediate properties. Three aspects are crucial for the production of PHA: the carbon source, the bacterial metabolic pathways and the PHA synthase enzyme. The PHA synthase catalyzes the polymerization of R-hydroxyacyl-CoA molecules forming biopolymer, and thus, the key enzyme in the biosynthesis of PHA. Four types of PHA synthases are known according to their substrate specificity and the peptide composition. Many studies have been undertaken to different compositions of the polymer. Thus, the aim of this paper was to search for genes encoding this enzyme, recombinant construction and assessment carrying such genes to find materials with new properties and applications. Initially we searched for new PHA synthase genes from 390 clones of a metagenomic library by PCR as previously detected positive for any type of PHA synthase. Later, two new sources of PHA synthase were sought: genes encoding PHA synthase III Thiocapsa pfennigii and Allochromatium vinosum. Out of 390 clones, only 2 showed positive for PHA synthase class II by PCR and sequencing reaction, showing similarity to known genes. Because of the fact that the type II PHA synthases has already been widely studied, unlike those of the type III, most promising for this work, coding genes were sought to test their integration in host able to accumulate high concentrations of PHA, but affected in its native PHA synthase (Pseudomonas putida and Burkholderia sacchari), evaluating the type of PHA produced Thus, recombinant Pseudomonas $s p$ and $B$. sacchari were built by the introduction of $T$. pfennigii genes $\left(p h a E C_{T p}\right.$ ) and $C$. vinosum $\left(p h a E C_{C v}\right.$ ) cloned into pBBR1-MCS2. The PHA production by recombinant obtained was qualitatively assessed by staining tests with Sudan Black B, indicated positive results only in Burkholderia sacchari harboring the gene $C$. vinosum being that Pseudomonas putida for housing phaEC $C_{C v}$ and phaEC $C_{T p}$ and Burkholderia sacchari phaEC $C_{T p}$ the result was negative . Quantitatively, PHA production was assessed in shake flask tests, using glucose and fatty acids containing from 3 to 9 carbons. The expression of genes in B. sacchari phaEC $C_{V}$ PHA was successful, since they were able to restore the production of PHA in the mutant. Using glucose, both the wild type strain and the recombinant Burkholderia sacchari produced a PHA composed of monomers of 3-hydroxybutyrate (3HB). From hexanoate and glucose gave a copolymer in which the $3 \mathrm{HHx}$ was increased fraction of $0.30 \mathrm{~mol} \%$ in the wild type strain to $1.85 \mathrm{~mol} \%$ in the mutant strain. Pseudomonas putida harboring phaEC $C_{v}$ produced a PHA in which there was an increase in $3 \mathrm{HHx}$ fraction from 0 to $9.11 \mathrm{~mol} \%$ when glucose was supplied as a carbon source. These lines can be used to produce PHA with varied composition, controlling the incorporation of $3 \mathrm{HHx}$ fractions which should reflect on their properties, expanding its application possibilities.

Keywords: PHA. Metagenomics. Pseudomonas. Burkholderia. PHA synthase. 


\section{LISTA DE FIGURAS}

Figura 1-Célula bacteriana contendo grânulos intracelulares de PHA (fotomicrografia eletrônica). .24

Figura 2-Fórmula genérica de monômeros detectados em PHA. R: radical; n: número de átomos de carbono. .25

Figura 3-Modelo metabólico genérico para a síntese de PHA . .26

Figura 4-Classes de PHA sintases. .27

Figura 5-Organização genética de diversos locus de pha e exemplos de espécies de bactérias apresentando cada organização.

Figura 6- Perfil eletroforético em gel de agarose $0.8 \% \quad(\mathrm{p} / \mathrm{v})$, mostrando o resultado da extração plasmidial dos clones A8,A4,E2,F5,B9,D6,F6,E6,G8,D5,C2 E A6 da placa 23. A seta indica a presença dos plasmídeos, próximo ao tamanho de 20.000 pb.

Figura 7-Perfil eletroforético em gel de agarose $0.8 \%(\mathrm{p} / \mathrm{v})$ mostrando a amplificação obtida na reação de PCR pelo primer phaCF1/CR4 na presença de pJM9131(1) e pBHR71 (8) e a ausência de fragmentos quando DNA de B.megaterium foi utilizado como molde (9).A caneleta 2 mostra a amplificação obtida com os primers I-179L (a)/I-179R(a), tendo pBHR71 como molde.Esses primers também foram utilizados nas reações presentes na canaletas 4 e 7 , contendo como molde pJM9131 e B. megaterium respectivamente. Os primers B1F/B1R foram utilizados nas reações das canaletas 3,5 e 6, tendo como DNA molde B.megaterium, pJM9131,e pBHR71 respectivamente.

Figura 8-Perfil eletroforético em gel de agarose $0.8 \%$ (p/v) resultante da amplificação por PCR dos clones descritos acima, com o par de primer 179L (a)/I-179R(a)

Figura 9-Perfil eletroforético em gel de agarose $0.8 \%(\mathrm{p} / \mathrm{v})$ resultante da amplificação por PCR dos clones descritos acima com o par de primer 179L (a)/I-179R(a). 
Figura 10-Perfil eletroforético em gel de agarose $0.8 \%(\mathrm{p} / \mathrm{v})$ resultante da amplificação por PCR dos clones descritos acima com o par de primer phaCF1/phaCR4. .53

Figura 11-Perfil eletroforético em gel de agarose $0.8 \%(\mathrm{p} / \mathrm{v})$ resultante da amplificação por PCR dos clones descritos acima com o par de primer phaCF1/phaCR4. .53

Figura 12-Perfil eletroforético em gel de agarose $0.8 \%(\mathrm{p} / \mathrm{v})$ resultante da amplificação por PCR dos clones descritos acima com o par de primer phaCF1/phaCR4 para a classe I e 179L (a)/I-179R(a) para a classe II. .54

Figura 13-Perfil eletroforético em gel de agarose $0.8 \%(\mathrm{p} / \mathrm{v})$ resultante da amplificação por PCR dos clones descritos acima com o par de primer BIF/BIR.As setas vermelhas indicam os amplicons que foram enviados para o sequenciamento. .55

Figura 14-Perfil eletroforético em gel de agarose $0.8 \%(\mathrm{p} / \mathrm{v})$ resultante da amplificação por PCR dos clones descritos acima com o par de phaCF1/phaCR4 para a classe I e BIF/BIR para a classe IV. .55

Figura 15- Perfil eletroforético em gel de agarose $0.8 \%(\mathrm{p} / \mathrm{v})$ resultante da amplificação por PCR dos clones descritos acima com o par de primer I-179L (a)/I-179R(a). .56

Figura 16- Perfil eletroforético em gel de agarose $0.8 \%(\mathrm{p} / \mathrm{v})$ resultante da amplificação por PCR dos clones descritos acima com o par de primer BIF/BIR. .56

Figura 17-Perfil eletroforético em gel de agarose $0.8 \%(\mathrm{p} / \mathrm{v})$ resultante da amplificação por PCR dos clones descritos acima com o par de primer BIF/BIR. .57

Figura 18-Perfil eletroforético em gel de agarose $0.8 \%(\mathrm{p} / \mathrm{v})$ resultante da amplificação por PCR dos clones descritos acima com o par de primer BIF/BIR. .57

Figura 19-Perfil eletroforético em gel de agarose $0.8 \%(\mathrm{p} / \mathrm{v})$ resultante da amplificação por PCR dos clones descritos acima com o par de primer BIF/BIR .58

Figura 20- Perfil eletroforético em gel de agarose $0.8 \%(\mathrm{p} / \mathrm{v})$ resultante da amplificação por PCR dos clones descritos acima com o par de primer phaCF1/phaCR4. .58 
Figura 21-Perfil eletroforético em gel de agarose $0.8 \%(\mathrm{p} / \mathrm{v})$ resultante da amplificação por PCR dos clones descritos acima com o par de primer I-179L (a)/I-179R(a). .59

Figura 22-Perfil eletroforético em gel de agarose $0.8 \%(\mathrm{p} / \mathrm{v})$ resultante da amplificação por PCR dos clones descritos acima com o par de primer I-179L (a)/I-179R(a). As setas vermelhas, indicam os amplicons que foram enviados para o sequenciamento. .59

Figura 23-Perfil eletroforético em gel de agarose $0.8 \%(\mathrm{p} / \mathrm{v})$ resultante da amplificação por PCR dos clones descritos acima com o par de primer I-179L (a)/I-179R(a) para classe II e BIF/BIR para classe IV. 60

Figura 24-Perfil eletroforético em gel de agarose $0.8 \%(\mathrm{p} / \mathrm{v})$ resultante da amplificação por PCR dos clones descritos acima com o par de primer P1/P2 para as caneletas 1 e 4, phaC3F/phaC3F para as canaletas 2 e 6 e Haphapcr1/ Haphapcr2 para as canaletas 3 e 5 . Todos esses primers são utilizados para a detecção de phaC de classe III. As setas vermelhas indicam os amplicons que foram enviados para sequenciamento 60

Figura 25-Perfil eletroforético em gel de agarose $0.8 \%(\mathrm{p} / \mathrm{v})$ resultante da amplificação por PCR dos clones descritos acima com o par de primer phaC $3 \mathrm{~F} / \mathrm{phaC} 3 \mathrm{~F}$. 61

Figura 26-Perfil eletroforético em gel de agarose $0.8 \%(\mathrm{p} / \mathrm{v})$ resultante da amplificação por PCR dos clones descritos acima com o par de primer phaC3F/phaC3F. 61

Figura 27-Perfil eletroforético em gel de agarose $0.8 \%(\mathrm{p} / \mathrm{v})$ resultante da amplificação por PCR dos clones descritos acima com o par de primer phaC $3 \mathrm{~F} / \mathrm{phaC} 3 \mathrm{~F}$. .62

Figura 28-Perfil eletroforético em gel de agarose $0.8 \%(\mathrm{p} / \mathrm{v})$ resultante da amplificação por PCR do plasmídeo do clone P34H3, utilizando-se o par de primer.. .69

Figura 29-Perfil eletroforético em gel de agarose $0.8 \%(\mathrm{p} / \mathrm{v})$ resultante da amplificação por PCR do plasmídeo do clone P34E10, utilizando-se o par de primer I-179R(a)/Sp6 e I-179L (a)/ T7. A sequência dos primers Sp6 e T7 está presente no vetor pBAC/oriV. .72 
Figura 30- Eletroforese em gel de agarose 0,8\%, resultante da PCR das cianobactérias Spirulina sp e Synechococcus sp utilizando os pares de primer P1/P2, Haphapcr1/2,phaE3R/F e phaC3R/F.O controle positivo nesse caso é plasmídeo pBluescript SK::B28+ .76

Figura 31- Perfil eletroforético em gel de agarose $0.8 \%(\mathrm{p} / \mathrm{v})$ da reação de pcr das colônias TGR1, TGR2, TGR3 e pds37, com os primers P1/P2, Haphapcr1/2,phaE3R/F e phaC3R/F..78

Figura 32- Perfil eletroforético dos fragmentos resultantes da digestão do plasmidio pds37::phaCE.1-pds37 sem digerir, 2- Digestão simples com PvuI e 3- Digestão dupla com EcoRI e PvuI. .79

Figura 33-Perfil eletroforético dos amplicons resultantes de uma reação de PCR com diferentes temperaturas de anelamento. $1-60^{\circ} \mathrm{C}, 2-62,8^{\circ} \mathrm{C}, 3-65.5^{\circ} \mathrm{C}$ e $4-68^{\circ} \mathrm{C}$. .80

Figura 34-Perfil eletroforético resultante da amplificação do gene phaCE das colônias de B. sacchari 344 resultantes da eletroporação. Cada canaleta corresponde a um clone diferente. 81

Figura 35-Perfil eletroforético em gel de agarose $0.8 \%(\mathrm{p} / \mathrm{v})$, da digestão de pBluescript SK::B28+ com BamHI. A seta vermelha indica o inserto de $2.850 \mathrm{pb}$ contendo PHAC e PHAE de Thiocapsa pfennigii. .82

Figura 36-Perfil eletroforético em gel de agarose $0.8 \%(\mathrm{p} / \mathrm{v})$, da digestão de pBBR2 com BamHI. 83

Figura 37-Perfil eletroforético em gel de agarose $0.8 \%(\mathrm{p} / \mathrm{v})$ resultante da amplificação do gene phaC de B. sacchari. .84

Figura 38-Avaliação da capacidade de acúmulo de polímero pelos recombinantes, em colônias coradas por Sudan Black B. .85

Figura 39-Avaliação da capacidade de acúmulo de polímero pelos recombinantes, em colônias coradas por Sudan Black B. .86 


\section{LISTA DE TABELAS}

Tabela 1- Comparação entre as propriedades físicas e térmicas de diferentes polímeros... 30

Tabela 2-Bactérias e plasmídeos utilizados no trabalho.

Tabela 3-Composição do meio LBAC 37

Tabela 4-Composição do meio F2

Tabela 5-Composição da solução de elemento traço contido no meio F2 38

Tabela 6-Composição da solução de vitaminas contida no meio F2 38

Tabela 7-Oligonucleotídeos empregados na confrmação da presença dos genes phaC.

Tabela 8-Sequência dos primers que flanqueiam phaCE de Allochromatium vinosum, Thiocapsa pfennigii e Burkholderia sacchari respectivamente 45

Tabela 9-Condições de PCR do primer PFEcoRI phaCE/ PRXhoI phaCE 45

Tabela 10-Condições de PCR do primer phaCBSF/ phaCBSR .45

Tabela 11-Relação dos clones que não apresentaram viabilidade durante a recuperação da biblioteca metagenômica 48

Tabela 12-Avaliação da capacidade de produção de PHA por recombinantes de B. sacchari abrigando genes codificadores de PHA sintase do tipo III, a partir de glicose $(10 \mathrm{~g} / \mathrm{L})$ como única fonte de carbono 88

Tabela 13-Avaliação da capacidade de produção de PHA por B. sacchari LFM 101 abrigando o plasmídeo pBBR1-MSC2, a partir de glicose $(10 \mathrm{~g} / \mathrm{L})$ e ácidos orgânicos (1g/L). 
Tabela 14-Avaliação da capacidade de produção de PHA por B. sacchari LFM 344 abrigando o gene phaC de B. sacchari, a partir de glicose $(10 \mathrm{~g} / \mathrm{L})$ e ácidos orgânicos $(1 \mathrm{~g} / \mathrm{L})$. .. 90

Tabela 15-Avaliação da capacidade de produção de PHA por B. sacchari LFM 344 abrigando o gene phaC de Allochromatium vinosum , a partir de glicose (10g/L) e ácidos orgânicos $(1 \mathrm{~g} / \mathrm{L})$. .91

Tabela 16-Avaliação da capacidade de produção de PHA por recombinantes de Pseudomonas putida abrigando genes codificadores de PHA sintase do tipo III, a partir de glicose $(10 \mathrm{~g} / \mathrm{L})$ como única fonte de carbono. .92

Tabela 17-Análise da concentração de ácidos orgânicos nas diferentes linhagens, com 24 e 72 horas de cultivo .93 


\section{LISTA DE ABREVIATURAS E SIGLAS}

3HB - 3-hidroxibutirato

3HD - 3-hidroxidecanoato.

3HDD - 3-hidroxidodecanoato

3HHp - hidroxiheptanoato

3HHx - 3-hidroxihexanoato

3HHx - 3-hidroxihexanoato

3HO - 3-hidroxioctanoato

3HV - 3-hidroxivalerato

3MASCL - 3-malonoil-CoA de cadeia curta (4 carbonos)

4HB - 4-hidroxibutirato

AcCoA - acetil-CoA

$A m p^{S}$ - sensibilidade à ampicilina;

$\mathrm{CG}$ - cromatografia gasosa

CoA - acetil-CoenzimaA

CoA - coenzima A

HA - hidroxiacil-CoA.

HA $_{\text {LCL }}$ - hidroxiacil-CoA de cadeia longa (mais de 14 carbonos) (do inglês Long Chain Length)

$\mathrm{HA}_{\mathrm{MCL}}$ - hidroxiacil-CoA de cadeia média (6-14 carbonos) (do inglês Mediu

$\mathrm{HA}_{\mathrm{SCL}}$ - hidroxiacil-CoA de cadeia curta (3-5 carbonos) (do inglês Short Chain Length)

HPLC - cromatografia líquida, do inglês High Performance Liquid Chromatography

IPTG - isopropil-tio- $\beta$-D- galactosídeo

$\mathrm{Km}^{\mathrm{R}}$ - resistência à canamicina;

$\mathrm{Km}^{\mathrm{S}}$ - sensibilidade à canamicina; 
LB - Luria Bertani

MM - meio mineral

MSC -massa seca celular

$\mathrm{P}(3 \mathrm{HB})$ - poli-3-hidroxibutirato

$\mathrm{P}(3 \mathrm{HB}-c o-3 \mathrm{HA})$ - poli(3-hidroxibutirato-co-3-hidroxialcanoato).

$\mathrm{P}(3 \mathrm{HB}-c o-3 \mathrm{HHx})$ - poli(3-hidroxibutirato-co-3-hidroxihexanoato)

$\mathrm{P}(3 \mathrm{HB}-c o-3 \mathrm{HV})$ - poli(3-hidroxibutirato-co-3-hidroxivalerato)

$\mathrm{P}(3 \mathrm{HHx})$ - poli(3-hidroxihexanoato).

$\mathrm{P}(3 \mathrm{HHx}-c o-3 \mathrm{HO})$ - poli(3- hidroxihexanoato -co-3-hidroxioctanoato)

$P C R$ - reação de polimerização em cadeia, do inglês Polymerase Chain Reaction

$\mathrm{PHA}^{-}$- ausência de acúmulo de PHA;

PHA - polihidroxialcanoato

$\mathrm{PHA}^{+}$- acúmulo de PHA;

phaA - gene codificador da enzima $\beta$-cetotiolase

PhaA - $\beta$-cetotiolase

phaB - gene codificador da enzima acetoacetil-CoA redutase

PhaB -acetoacetil-CoA redutase NADPH dependente

phaC - gene codificador da enzima PHA sintase ou polimerase

PhaC - PHA sintase ou polimerase

PhaE - subunidade da enzima PHA sintase de classe III

PHAMCL - polihidroxialcanoato com monômeros de cadeia média (6-14 carbonos) (do inglês medium chain length)

PhaR - subunidade da enzima PHA sintase de classe IV

PHASCL - polihidroxialcanoato com monômeros de cadeia curta (3-5 carbonos) (do inglês short chain length)

PhaZ - enzimas despolimerizadoras de PHA (despolimerases) 
$\mathrm{Tc}^{\mathrm{R}}-$ resistência à tetraciclina.

$\mathrm{Tc}^{\mathrm{S}}$ - sensibilidade à tetraciclina;

$\mathrm{T}_{\mathrm{m}}-$ temperatura de fusão

XGal - 5-bromo-4-cloro-3-indolil- $\beta$-D- galactosídeo 


\section{SUMÁRIO}

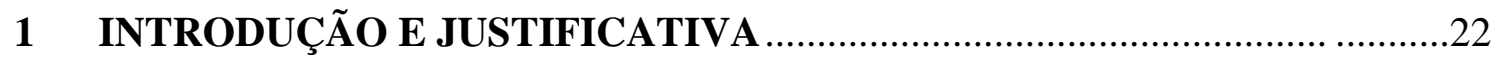

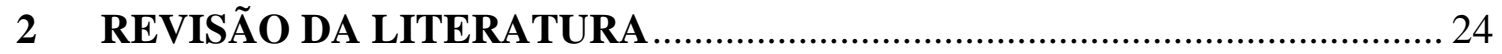

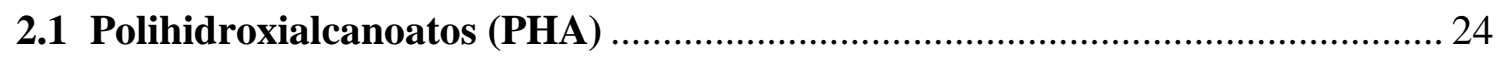

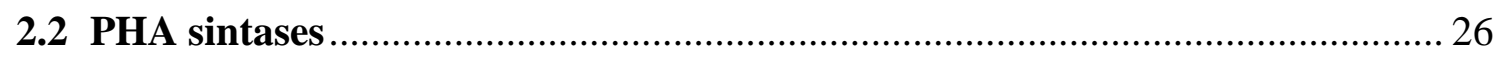

2.3 Biossíntese de PHA e suas diferentes composições ……………………………... 29

2.4 Seleção em biblioteca metagenômica por genes codificadores de PHA sintases 30

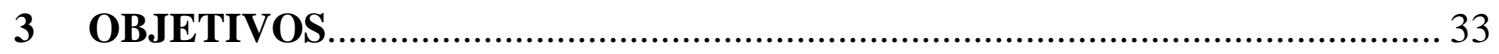

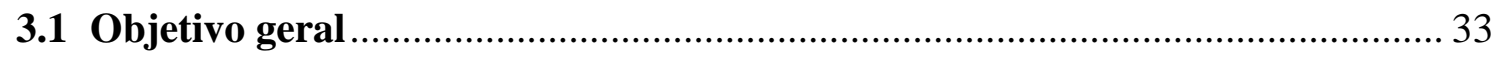

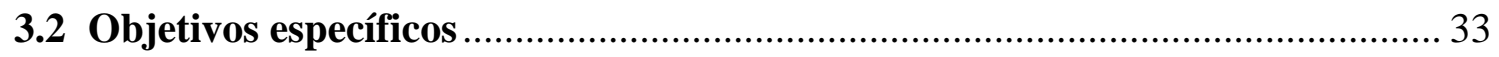

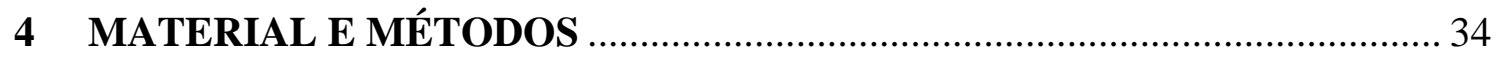

4.1 Microrganismos, plasmídios e preservação ………………………………....... 34

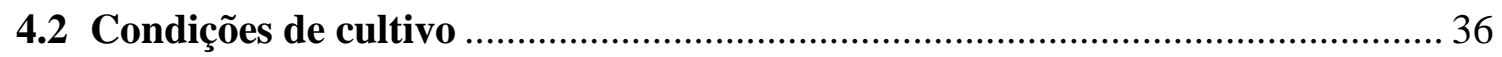

4.3 Meios de cultura ............................................................................................... 37

4.4 Recuperação dos clones da biblioteca metagenômica …………………………... 38

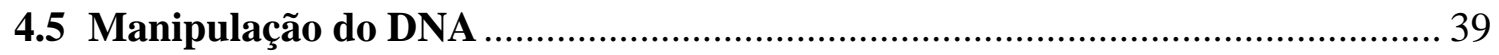

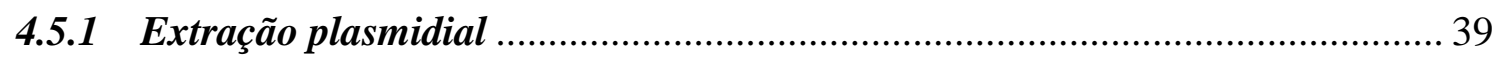

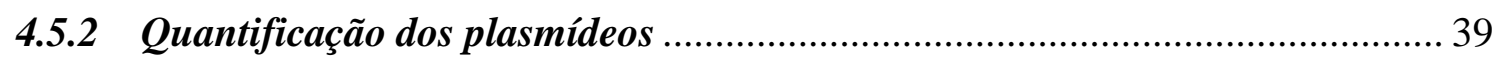

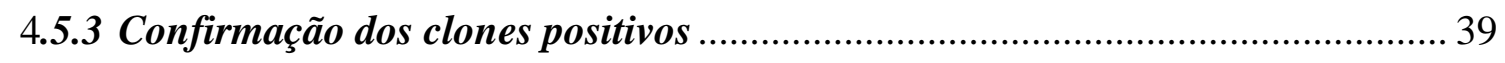

4.5.4 Digestão dos clones com enzimas de restrição ……………………………….... 41

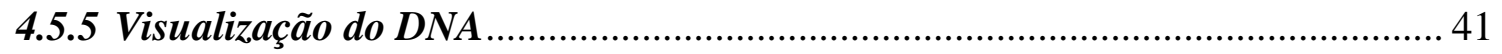

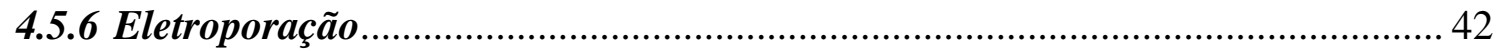

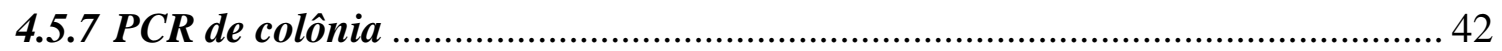

4.5.8 Purificação dos produtos de PCR obtidos ......................................................... 43

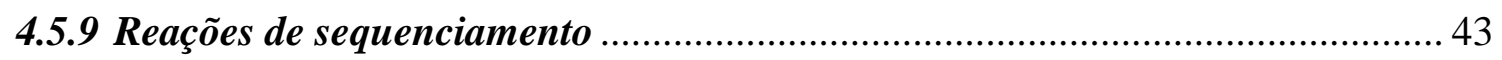

4.5.10 Análise das sequências ................................................................................... 43

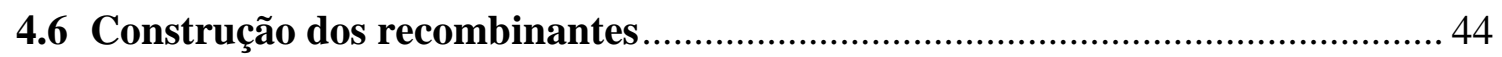

4.7 Avaliação da capacidade dos recombinantes no acúmulo de PHA …………... 46

4.7.1 Teor e composição do polímero …………………………………………….... 46

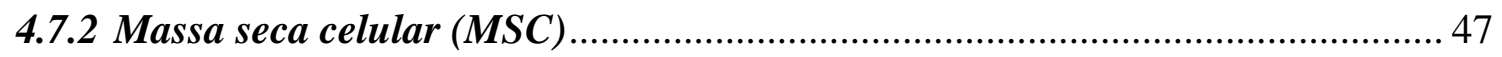

4.8 Determinação da concentração de ácidos orgânicos ………………………….... 47

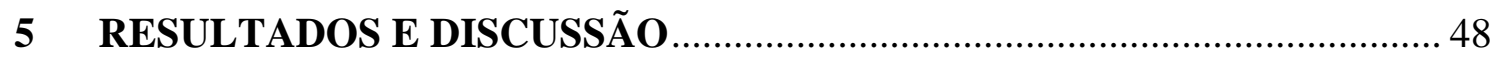




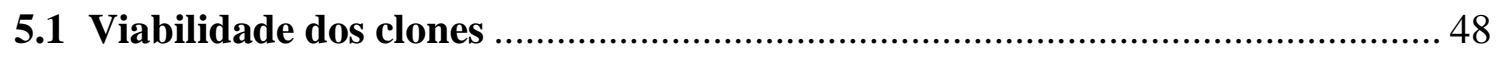

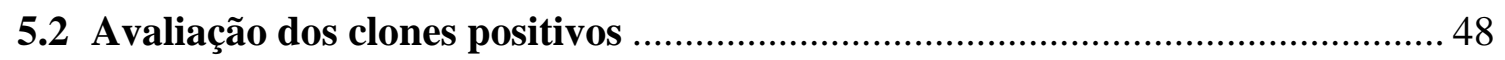

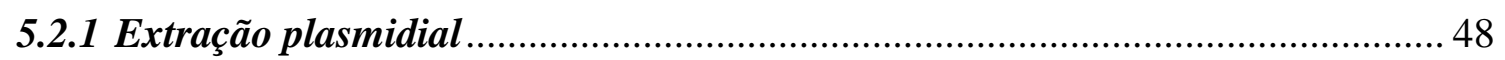

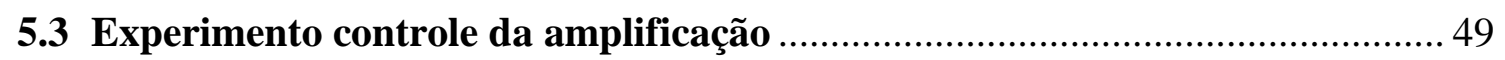

5.4 Sequenciamento de fragmentos de DNA dos clones positivos ........................... 65

5.5 Amplificação e sequenciamento do inserto dos clones Classe II positivos ........ 68

5.6 Detecção da presença do gene phaC em Spirulina sp e Synechococcus sp....... 75

5.7 Confirmação da presença do gene phaC no plasmídeo pBluescript SK-

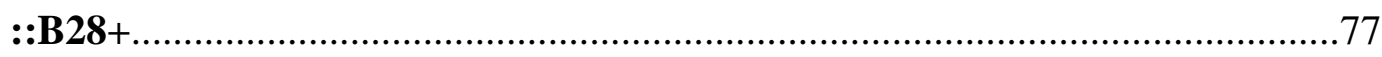

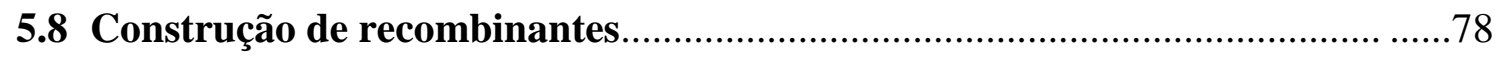

5.9 Construção do pBBR1MCS-2 abrigando phaCE de Allochromatium

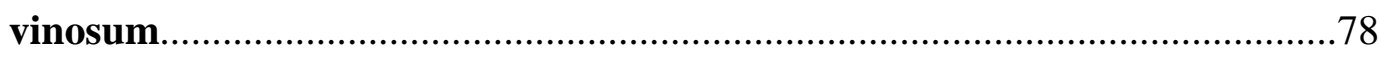

5.9.1 Construção do pBBR1MCS-2 abrigando phaCE de Thiocapsa pfennigii ..... 81

5.9.2 Construção do pBBR1MCS-2 abrigando phaC de Burkholderia sacchari.... 83

5.10 Avaliação da produção de PHA pelos recombinantes ..................................... 84

5.10.1 Avaliação qualitativa da produção de PHA em meio mineral sólido .............. 84

5.10.2 Avaliação quantitativa da produção de PHA em meio mineral líquido ......... 87

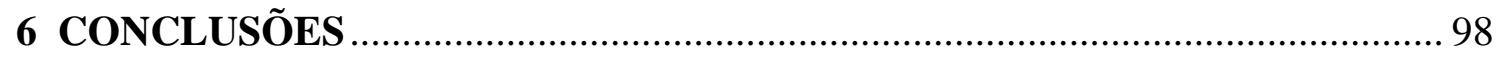

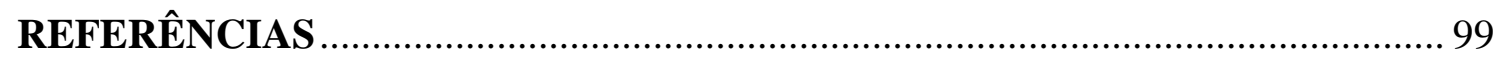

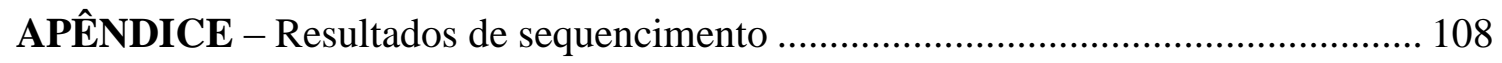




\section{INTRODUÇÃO E JUSTIFICATIVA}

Os plásticos têm grande influência na sociedade moderna e estão presentes na vida das pessoas com diversas aplicações, sendo uma delas a substituição de matérias-primas convencionais como metais, vidros, papéis e madeira. Há também sua aplicação na manufatura de embalagens e outros produtos por causa de sua praticidade e descartabilidade rápida. Entre os diversos polímeros de uso na sociedade atual, os plásticos sintéticos têm sido os mais utilizados (PEREIRA, 2002, 2007).

No entanto, devido a sua lenta degradabilidade e ao descarte volumoso dos plásticos sintéticos é cada vez maior a preocupação com os impactos ambientais e as consequiências à saúde e à vida na Terra. Uma vasta gama de alternativas biodegradáveis têm sido propostas para substituir os plásticos convencionais (SILVA et al., 2007).

Dentre os substitutos em desenvolvimento encontram-se os polímeros de amido modificado (combinado com polipropileno, polietileno, poliestireno, etc.), poli-e-caprolactona (PCL), copoliésteres de acetato de celulose, álcool polivinílico (PVOH) e polihidroxialcanoatos - PHA (PEREIRA, 2002; PRADELLA, 2006).

Polihidroxialcanoatos (PHA) são poliésteres acumulados por diversas bactérias a partir de fontes renováveis que despertam grande interesse industrial por serem termoplásticos, biodegradáveis e biocompatíveis. A variabilidade da composição monomérica de PHA determina suas propriedades mecânicas e permite seu uso em diversas aplicações. Os PHA podem ser formados por monômeros de cadeia curta (PHASCL) ou média (PHAMCL), ou ainda, formar copolímeros $\left(\mathrm{PHA}_{\mathrm{SCL}}-\mathrm{PHA} \mathrm{MCL}\right)$ que têm propriedades intermediárias (ANDERSON; DAWES, 1990; GOMEZ, 2000b; STEINBÜCHEL, 1993).

A PHA sintase é a enzima chave para a biossíntese de PHA, sendo responsável pela catálise da polimerização das moléculas $R$-hidroxiacil-CoA formando o biopolímero. Entretanto sua especificidade e limitações metabólicas dos organismos produtores restringem a composição monomérica do PHA produzido e consequentemente das suas propriedades e aplicações (REHM, 2003).

A expressão de genes codificadores de PHA sintase em hospedeiros heterólogos tem levado à produção de PHA com novas propriedades (BOCANEGRA et al., 2013; SCHONEBAUM; STEINBUCHEL, 1996; VALENTIN et al., 1994). Nesse aspecto, é importante estudar as bibliotecas metegenômicas que além de fornecerem dados importantes sobre as características populacionais microbianas (RODRIGO et al., 2006) são também uma 
importante fonte de novos genes, principalmente provenientes de organismos não cultiváveis (ATLAS; BARTHA, 1997; GILLESPIE et al., 2002; LEFEVRE et al., 2008). Além disso, também é possível buscar organismos produtores de PHA como fonte de genes para expressão heteróloga.

Neste contexto, esse trabalho buscará diferentes genes para a expressão heteróloga em organismos produtores já conhecidos e avaliará se novos genes ou PHA com diferentes propriedades podem ser encontrados. 


\section{REVISÃO DA LITERATURA}

\subsection{Polihidroxialcanoatos (PHA)}

Os PHA são poliésteres acumulados por diversas bactérias, na forma de grânulos intracelulares (Figura 1) que atuam como reserva de energia e equivalentes redutores na ausência de fonte de carbono externa. (SUDESH et al., 2000; REHM, 2003). A síntese de PHA normalmente ocorre de modo mais expressivo quando há excesso de fonte de carbono disponível e limitação de pelo menos um nutriente essencial à multiplicação das células bacterianas (N, P, Mg, Fe, etc.)(GOMEZ, 2000b; SIMON-COLIN et al., 2008). Por outro lado, quando há limitação de carbono ou energia, mas não de outros nutrientes, os PHA podem ser reutilizados para suprir essa necessidade (ANDERSON; DAWES, 1990; LEE et al., 1996).

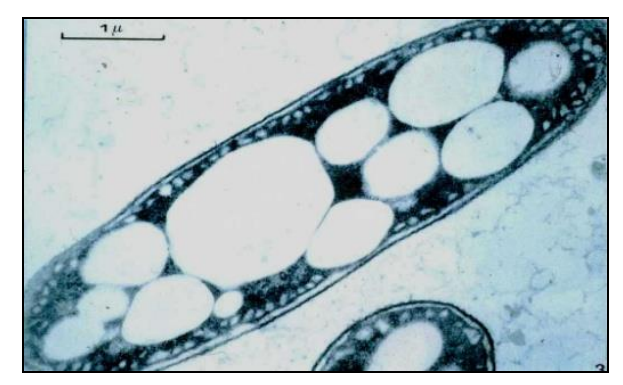

\begin{tabular}{llcrr} 
Figura 1-Célula & \multicolumn{3}{c}{ bacteriana } & contendo grânulos \\
intracelulares & de & PHA & (fotomicrografia \\
eletrônica).(Retirado & do & Link: & http://www.nrc- \\
cnrc.gc.ca/highlights/2007/0703maplesap_e.html).
\end{tabular}

As propriedades do PHA permitem que sejam utilizados como plásticos biodegradáveis, substituindo os convencionais, de origem petroquímica, em algumas aplicações, tais como, o uso em embalagens, filmes de recobrimento, aparatos médicos, aditivos para tintas e adesivos. As propriedades do polímero, bem como suas aplicações, dependem de sua composição monomérica. Uma fórmula genérica deste material está apresentada na Figura 2 (GOMEZ, 2000b; PARK et al., 2001). 
Atualmente, mais de 150 hidroxialcanoatos distintos já foram identificados como constituintes de PHA bacterianos nas mais variadas combinações, que incluem monômeros saturados e insaturados, ramificações, grupos funcionais na cadeia lateral (halogênios, aromáticos, etc.) ou ainda com o grupo hidroxila em diferentes posições ( GODOY et al., 2003; NODA et al., 2005; REHM ; STEINBÜCHEL, 1999;STEINBUCHEL; SILVA et al., 2007, VALENTIN, 1995; ZHENG et al., 2005;).

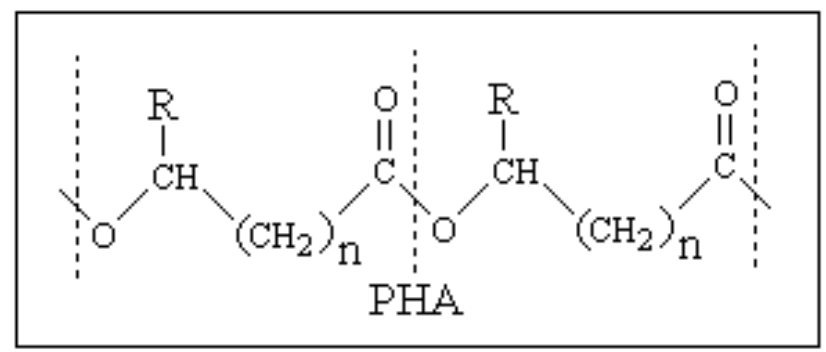

Figura 2-Fórmula genérica de monômeros detectados em PHA.

R: radical; n: número de átomos de carbono (Gomez, 2000b).

Os monômeros encontrados na composição de PHA são classificados em dois grandes grupos:

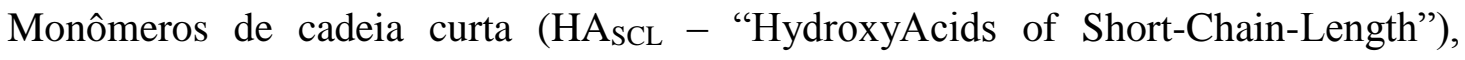
contendo de 3 a 5 átomos de carbono na cadeia principal;

Monômeros de cadeia média (HAMCL - "HydroxyAcids of Medium-Chain-Length"), contendo de 6 a 16 átomos de carbono na cadeia principal (Steinbuchel e Valentin, 1995; Gomez, 2000b; Simon-Colin et al., 2008).

Enquanto o primeiro grupo apresenta propriedades termoplásticas (alongamento para ruptura menor que 5\%), o segundo se apresenta como elastômero (alongamento para ruptura maior que $1000 \%$ ). A composição monomérica e a massa molecular do PHA são responsáveis por suas propriedades físicas e mecânicas. Do ponto de vista industrial é interessante o controle da composição monomérica porque isto influencia nas propriedades do material (PHA) e em suas diferentes aplicações. Por exemplo, as propriedades de PHA permitem a obtenção desde materiais rígidos, como o $\mathrm{P} 3 \mathrm{HB}$, a materiais flexíveis, como $\mathrm{PHA}_{\mathrm{MCL}}$, podendo também se apresentar como materiais viscosos e aderentes, que é o caso dos 
PHAs ${ }_{M C L}$ contendo uma grande fração de monômeros insaturados (GOMEZ, 2000b; STEINBÜCHEL; HEIN, 2001).

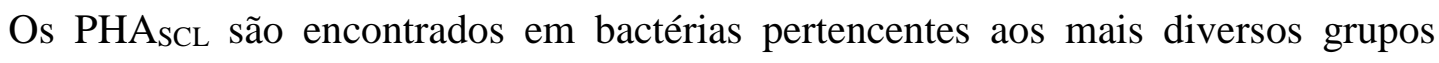
taxonômicos (STEINBÜCHEL, 1991), enquanto que os PHAMcL só foram detectados em Pseudomonas do grupo I de homologia do RNA ribossomal 16s (Pseudomonas sensu stricto) (HUISMAN et al., 1989). Apenas recentemente foi demonstrada a possibilidade de síntese de PHA contendo HAsCL e HAMCL em uma mesma cadeia polimérica (ABE et al., 1994; GOMEZ, 2000b; GOMES, 2009; MATSUDA, 2009; MENDONÇA, 2009; LIEBERGESELL; REHM et al., 2000 ; STEINBÜCHEL, 1993; VALENTIN et al., 1994).

\subsection{PHA sintases}

Embora um grande número de monômeros diferentes já tenha sido detectado como constituintes de PHA, convêm destacar que a síntese e incorporação destes monômeros depende do fornecimento de um substrato adequado, que possa ser convertido no hidroxiacilCoA desejado através das vias metabólicas existentes na célula bacteriana. Além disso, é necessário que a célula bacteriana contenha uma PHA sintase capaz de incorporar ao poliéster sendo formado o hidroxiacil-CoA gerado. A PHA sintase é a enzima chave para a biossíntese de PHA, sendo responsável pela catálise da polimerização das moléculas de $R$-hidroxiacilCoA formando o biopolímero (Figura 3) (GOMEZ, 2000b).

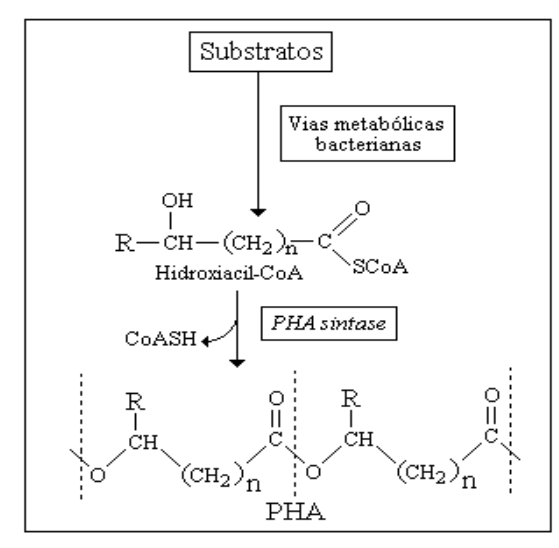

Figura 3-Modelo metabólico genérico para a síntese de PHA (GOMEZ, 2000b). 
Tanto a especificidade das vias metabólicas geradoras do hidroxiacil-CoA, como da PHA sintase, podem impedir a combinação de certos monômeros em uma mesma cadeia polimérica ou, ainda, restringir a quantidade de um determinado monômero que pode ser incorporada ao PHA (GOMEZ, 2000b; REHM, 2003).

Entre as estratégias mais comumente aplicadas para a produção de PHA com composição variada, a mais comum tem sido o fornecimento de fontes de carbono, carboidratos, resíduos industriais, ácidos graxos de cadeias longa ou curta, em geral diretamente relacionadas quimicamente ao polímero que se deseja produzir ( BUFFONI, 2006; STEINBUCHEL ; VALENTIN, 1995; SILVA et al., 2004). Este procedimento limita a natureza química do monômero incorporado, tanto pela oferta limitada de substratos (hidroxiacil-CoAs) à PHA sintase microbiana, como pela especificidade da mesma pelo substrato, além de incidir em maior custo na otimização do processo de produção industrial.

De acordo com a estrutura primária das sequências dos genes codificadores e da especificidade das PHA sintases pelo substrato, estas foram, recentemente, divididas em 4 classes, como mostra a figura 4 (REHM, 2003), que apresenta também as suas respectivas unidades características, espécies microbianas típicas e substrato preferencial.

\begin{tabular}{|c|c|c|c|}
\hline Classe & Subunidades & Espécies & Substrato \\
\hline I & $\underset{\sim 60-73 \mathrm{kDa}}{\text { Phad }}$ & Ralstonia eutropha & 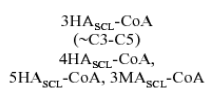 \\
\hline II & $\overbrace{\sim 60-65 \mathrm{kDa}}^{\text {Phad }}$ & Pseudomonas aeruginosa & $\underset{(\sim \geq \mathrm{C})}{3 \mathrm{HA}_{\mathrm{MLL}-\mathrm{COA}}}$ \\
\hline III & $\underset{\sim 40 \mathrm{kDa} \sim 40 \mathrm{kDa}}{\text { Phac PhaE }}$ & Allochromatium vinosum & 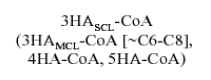 \\
\hline IV & $\underset{\sim 40 \mathrm{kDa} \sim 22 \mathrm{kDa}}{\text { Phad PhaR }}$ & Bacillus megaterium & $3 \mathrm{HA}_{\mathrm{scL}}-\mathrm{CoA}$ \\
\hline
\end{tabular}

Figura 4-Classes de PHA sintases (REHM, 2003), modificado

Associados aos genes codificadores da PHA sintase, são encontrados outros genes participantes na biossíntese de PHA, promovendo diferentes conteúdos monoméricos. Os 
produtos destes outros genes estão envolvidos em etapas como a biossíntese dos monômeros fornecidos à PHA sintase (como é o caso dos genes phaA, phaB, pha $C$, pha $R$ ), ou são componentes estruturais do grânulo de polímero (phaP) ou mobilizam os grânulos intracelulares (phaZ) (REHM, 2003; SPIEKERMANN et al., 1999; SOLAIMAN; ASHBY, 2005; VALENTIN et al., 1994). A Figura 5 apresenta a organização de genes próximos ao codificador da PHA sintase (phaC) em organismos portadores de diferentes classes desta enzima.

As PHA sintase de classe I é estruturalmente composta por uma subunidade $\mathrm{PhaC}$ enquanto as PHA sintases de classe II são compostas por duas subunidades PhaC1 e PhaC2. Além da diferença estrutural, ambas diferem na especificidade pelos substratos: PHA sintases da classe I, III e IV utilizam preferencialmente de cadeias curtas $(R)$-3-hidroxiacil-CoAs, enquanto a PHA sintase da classe II usa cadeias médias de $(R)$-3-hidroxiacil-CoA. As PHA sintases de classe III e IV distinguem-se das de classe I e II, pois possuem duas subunidades distintas PhaC e PhaE, PhaC e PhaR (figura 5) respectivamente (REHM; STEINBÜCHEL, 1999).

No Brasil, a produção de alguns tipos de PHA vem sendo estudada, destacando-se o homopolímero P3HB - homopolímero poli-3-hidroxibutirato e o copolímero de poli-3hidroxibutirato-co- 3- hidroxivalerato (P3HB-co-3HV), para gerar PHA mais maleáveis (SILVA et al., 2007). O interesse comercial por este polímero vem aumentando, no país graças à possibilidade de produzi-los a partir de fontes de carbono renováveis pela agricultura, como a sacarose, glicose, xilose e derivados do bagaço de cana-de-açúcar entre outros (HOLMES, 1985B; LOPES et al., 2009; LOPES et al., 2011;SILVA et al., 200). Leva-se em consideração neste caso, o fato de que o Brasil é um dos maiores produtores mundiais de açúcar, que o valor agregado de PHA é maior que o do álcool, além de poder se tornar num produto de exportação (BUENO NETO et al., 1991). 


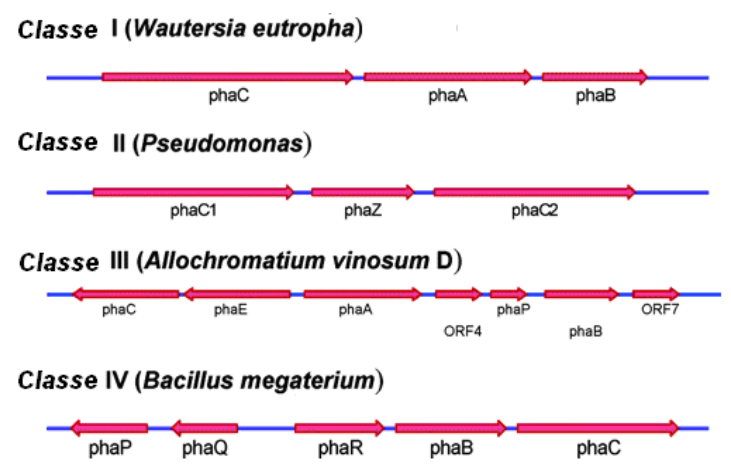

Figura 5-Organização genética de diversos loci envolvidos na produção de PHA e exemplos de espécies de bactérias apresentando cada organização (Solaiman e Ashby, 2005).

Os diversos trabalhos desenvolvidos no país até o momento focalizaram a busca, em fontes como o solo, por microrganismos produtores, PHAsCL e PHAMCL por meio de isolamento e cultivo de microorganismos ou melhoramento de linhagens pré-existentes em coleções microbianas (GOMEZ, 2000b; SILVA et al., 2007). A busca foi direcionada a microrganismos capazes de crescer e acumular PHA em produtos da agricultura, resíduos industriais ou produtos químicos com potencial para gerar novos materiais (BUFFONI, 2006; MENDONÇA et al., submetido; SILVA et al., 2007 ). Neste aspecto, o potencial da biodiversidade brasileira tem oferecido grandes perspectivas de obtenção de microrganismos, ainda não descritos, que apresentam a capacidade metabólica tanto da utilização de substratos não usuais, como da sua transformação em PHA.

\subsection{Biossíntese de PHA e suas diferentes composições}

O P3HB é produzido a partir da ação conjunta de três enzimas: $\beta$-cetotiolase (PhaA), enzima acetoacetil-CoA redutase (phaB) e pha sintase, como já dito anteriormente. A enzima $\beta$-cetotiolase (PhaA), codificada pelo gene phaA é responsável por condensar duas moléculas de acetil-CoA para gerar acetoacetil-CoA, o primeiro passo na síntese de $\mathrm{P}(3 \mathrm{HB})$. A condensação da molécula de acetil-CoA ocorre predominantemente após o período de crescimento bacteriano, mas não é inexistente nessa fase. A enzima acetoacetil-CoA redutase NADPH dependente ( $\mathrm{PhaB}$ ) é codificada pelo gene phaB e catalisa a reação de redução de acetoacetil-CoA a $(R)$-3-hidroxibutiril-CoA. A PHA sintase é a enzima responsável pela polimerização das moléculas de $R$-hidroxiacil-CoA formando o biopolímero (BRAUNEGG, et al., 1998). 
A copolimerização de $3 \mathrm{HB}$ com diferentes monômeros possibilita a obtenção de polímeros com diferentes propriedades, sendo possível a modificação de características como flexibilidade e temperatura de fusão (tabela 1). Dessa forma é possível que haja uma grande variabilidade na sua aplicação, podendo ser utilizados como embalagens, vasilhames e até mesmo produtos de uso médico e farmacêutico (fios de sutura, próteses ósseas e cápsulas para liberação controlada de fármacos) ( CHEN, 2009; PARK et al., 2012; PRADELLA, 2006).

Tabela 1- Comparação entre as propriedades físicas e térmicas de diferentes polímeros.

\begin{tabular}{|c|c|c|c|c|}
\hline Polímero & $\begin{array}{c}\mathbf{T}_{\mathbf{m}} \\
\left({ }^{\circ} \mathbf{C}\right)\end{array}$ & $\begin{array}{c}\mathbf{T}_{\mathbf{g}} \\
\left({ }^{\circ} \mathbf{C}\right)\end{array}$ & $\begin{array}{c}\text { Resistência à } \\
\text { Tensão } \\
\text { (MPa) }\end{array}$ & $\begin{array}{c}\text { Alongamento } \\
\text { para ruptura } \\
(\%)\end{array}$ \\
\hline $\mathrm{P}(3 \mathrm{HB})$ & 177 & 4 & 43 & 5 \\
\hline $\mathrm{P}(3 \mathrm{HB}-c o-10 \% \mathrm{HV})$ & 150 & - & 25 & 20 \\
\hline $\mathrm{P}(3 \mathrm{HB}-c o-20 \% \mathrm{HV})$ & 135 & - & 20 & 100 \\
\hline $\mathrm{P}(3 \mathrm{HB}-c o-3 \%$ 4HB $)$ & 166 & - & 28 & 45 \\
\hline $\mathrm{P}(3 \mathrm{BH}-\mathrm{co}-10 \%$ 4HB $)$ & 159 & - & 24 & 242 \\
\hline $\mathrm{P}(3 \mathrm{BH}-\mathrm{co}-64 \%$ 4HB $)$ & 50 & - & 17 & 591 \\
\hline $\mathrm{P}(3 \mathrm{HB}-c o-5 \% \mathrm{HHx})$ & 151 & 0 & - & - \\
\hline $\mathrm{P}(3 \mathrm{HB}-c o-10 \% \mathrm{HHx})$ & 127 & -1 & 21 & 400 \\
\hline $\mathrm{P}(3 \mathrm{HB}-c o-15 \% \mathrm{HHx})$ & 115 & 0 & 23 & 760 \\
\hline $\mathrm{P}(3 \mathrm{HB}-c o-17 \% \mathrm{HHx})$ & 120 & -2 & 20 & 850 \\
\hline $\mathrm{P}(3 \mathrm{HB}-c o-19 \% \mathrm{HHx})$ & 111 & -4 & - & - \\
\hline $\mathrm{P}(3 \mathrm{HB}-c o-25 \% \mathrm{HHx})$ & 52 & -4 & - & - \\
\hline $\mathrm{PHO}$ & 61 & -35 & 9 & 380 \\
\hline Polipropileno & 170 & - & 34 & 400 \\
\hline Poliestireno & 110 & - & 50 & - \\
\hline PET & 262 & - & 56 & 730 \\
\hline HDPE & 135 & - & 29 & - \\
\hline LDPE & 130 & -30 & 10 & 620 \\
\hline
\end{tabular}

3HB: 3-hidroxibutirato; 4HB: 4-hidroxibutirato; HV: 3-hidroxivalerato; HHx: 3-hidroxihexanoato, HO: 3hidroxioctanoato, PET - polietileno tereftalato, HDPE - polietileno de alta densidade, LDPE - polietileno de baixa densidade, $\mathrm{T}_{\mathrm{m}}$ - temperatura de fusão; Tg temperatura de transição vítrea. Fontes: Holmes (1988); King (1982); Doi, Kitamura e Abe (1995); Sudesh, Abe e Doi (2000); Khanna; Srivastava (2005); Pradella (2006); Carminatti et al. (2006)

\subsection{Seleção em biblioteca metagenômica por genes codificadores de PHA sintases}

Apesar do potencial da biodiversidade do ambiente, os métodos tradicionais de isolamento e cultivo para análise da diversidade microbiana do meio ambiente são limitados, 
pois poucos microrganismos são cultiváveis (ATLAS; BARTHA, 1997; PEREIRA, 2003). O uso recente de ferramentas moleculares e tecnologias baseadas em seqüências gênicas vem sendo empregados com sucesso para análise da diversidade microbiana dos solos (BORNEMAN; TRIPLETT, 1997; RODRIGO et al., 2006; TORSVIK et al., 1998), na clonagem de grandes fragmentos de DNA para isolamento de antibióticos de bibliotecas metagenômicas, assim como para estudar a fisiologia de microrganismos não cultiváveis em comunidades do solo (GILLESPIE et al., 2002; PEREIRA, 2003; LEFEVRE et al., 2008).

Metagenoma é uma técnica que analisa o conjunto de genomas encontrado na microbiota total de determinado habitat. Dessa forma, oferece uma alternativa para acessar mais amplamente a diversidade microbiana total de um determinado ambiente, permitindo a análise de genes funcionais e compostos bioativos em um número maior do que as técnicas tradicionais de cultivo permitem (LORENZ et al., 2002; LORENZ; ECK, 2005; PEREIRA, 2003).

Nesse contexto, alguns trabalhos já foram feitos, no sentido de buscar novos genes de PHA sintase em bibliotecas metagenômicas e as metodologias e técnicas utilizadas para o screening são bastante variáveis. Uma das técnicas utilizadas para o screening é a construção de macro arranjos a partir dos clones obtidos onde pôde-se buscar os genes de PHA sintase através de sondas. Há relato da utilização desse tipo de screening em solo e sedimentos coletados sob diversas condições (como contaminação por óleo), em que foram encontradas PHA sintases de classe I, II e III (DIMITROV, 2009).

Outra abordagem que pode ser utilizada e já foi descrita na literatura é a busca de clones positivos a partir do fenótipo. Nesse caso a biblioteca é construída em vetores, como cosmídeos, que são transferidos para uma bactéria mutante PHA negativa, com mutação no gene da PHA sintase. Quando o gene da PHA sintase está presente no vetor, o fenótipo da bactéria é restabelecido, e ela se torna capaz de produzir PHA comprovando a existência do gene na biblioteca. Utilizando essa metodologia obteve-se sucesso em encontrar novos tipos de PHA sintase (ANEJA et al., 2004; SCHALLMEY et al., 2011).

Em outro trabalho recentemente desenvolvido (GALINDO, 2011) buscou-se por genes codificadores de PHA sintases, empregando técnicas de PCR em uma biblioteca metagenômica construída a partir de solo de Mata Atlântica (MASSINI, 2004) e disponibilizada pelo Prof. Gabriel Padilla do ICB USP. Os testes funcionais não foram relevantes para auxiliar nesta seleção. Foi gerada uma pequena coleção de clones (cerca de 300 clones) promissores detectados por PCR. Aproximadamente 70 geraram amplicons a 
partir de primers para classe III, entretanto, sequenciamento de alguns clones selecionados ao acaso indicou similaridade com genes codificadores de enzimas diferentes de PHA sintases.

O primeiro critério de seleção, focou analisar potenciais genes de classe III, visto que, embora detectadas em algumas bactérias, apenas poucas destas foram descritas e, entre estas poucas, uma, isolada de Thiocapsa pfenigii, já demonstrou especificidade por maior número de substratos e sua expressão em Pseudomonas putida revelou a produção de HASCL com

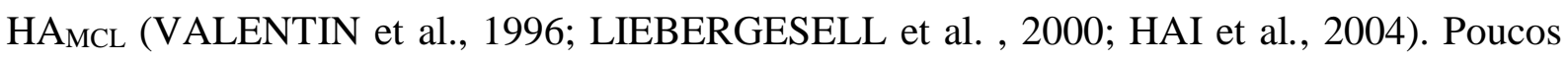
trabalhos empregaram tais genes para clonagem e expressão em hospedeiros $\mathrm{PHA}^{-}$com diferentes arcabouços metabólicos para avaliar que PHA seriam gerados. A maioria emprega PHA sintases de classe I para obter tais materiais. Nosso grande interesse no momento são combinações de $\mathrm{HASCL}_{\mathrm{SC}}$ com HAMCL, que apresentam propriedades intermediárias às de HASCL ou $\mathrm{HA}_{\mathrm{MCL}}$ isoladamente. Apenas recentemente, em algumas bactérias halofílicas, PHA sintases relacionadas com classe I e III foram detectadas, propondo-se que estas últimas

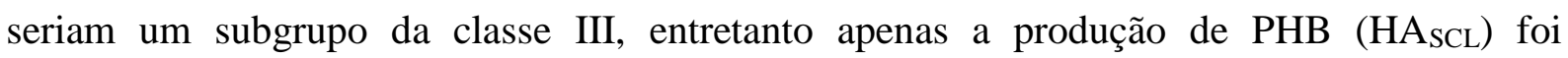
observada e nas próprias cepas selvagens (QUILLAGUAMÁN et al., 2010; POLI et al., 2011).

Outro dado importante, com relação às PHA sintases de classe IV (descritas em Bacillus) é que apenas recentemente foi reportada sua expressão na bactéria Gram negativa Ralstonia eutropha, mostrando que, dependendo da origem bacteriana da enzima, especificidades mais relaxadas podem ser observadas e também a formação do polímero alvo mencionado (HYAKUTAKE et al., 2011). Dentro desse contexto foi proposto o presente trabalho. 


\section{OBJETIVOS}

\subsection{Objetivo geral}

Construir recombinantes em hospedeiros PHA negativos, abrigando PHA sintases heterólogas, avaliando se sua expressão em hospedeiros metabolicamente distintos leva à obtenção de PHA com composição monomérica distinta, que resultem em propriedades intermediárias às dos PHA já descritos.

\subsection{Objetivos específicos}

- Reavaliar os 390 clones positivos obtidos anteriormente;

- Selecionar os clones positivos mais promissores para clonagem em hospedeiros PHA negativos;

- Buscar organismos portadores de PHA sintases de classe III para a expressão heteróloga;

- Avaliar o PHA produzido pelos recombinantes 


\section{MATERIAL E MÉTODOS}

\subsection{Microrganismos, plasmídios e preservação}

As linhagens, os plasmídios e os genes que foram utilizados neste trabalho estão descritos na Tabela 1. Poderão ser utilizados, ainda, outros microrganismos. A preservação foi feita por liofilização (SILVA et al., 1992) ou suspensão em glicerol $(20 \% \mathrm{~m} / \mathrm{v})$ e estoque em freezer a $80^{\circ} \mathrm{C}$.

Tabela 2-Bactérias e plasmídeos utilizados no trabalho.

\begin{tabular}{|c|c|c|}
\hline Bactérias/Plasmídeos & Características & Referência \\
\hline $\begin{array}{l}\text { Bacillus megaterium M.A } \\
3.3\end{array}$ & Isolado bacteriano produtor de PHA. & $\begin{array}{l}\text { (Lopes et al., } \\
\text { 2009) }\end{array}$ \\
\hline $\begin{array}{l}\text { Burkholderia sacchari } \\
\text { LFM } 101\end{array}$ & $\mathrm{Sac}^{+}, \mathrm{PHA}^{+}, \mathrm{Hx}^{+}, \mathrm{Kan}^{\mathrm{s}}, \mathrm{Amp}^{\mathrm{s}}, \mathrm{Tc}^{\mathrm{s}}$ & $\begin{array}{l}\text { (Bramer et al., } \\
\text { 2001) }\end{array}$ \\
\hline B. sacchari LFM936 & $\begin{array}{l}\text { Burkholderia sacchari LFM101 abrigando plasmídio pBBR1MCS-2 } \\
\text { vazio }\end{array}$ & Este trabalho \\
\hline $\begin{array}{l}\text { Burkholderia sacchari } \\
\text { LFM344 }\end{array}$ & $\begin{array}{l}\text { Mutante UV de LFM 101, PHA', afetado no gene phaC (PHA } \\
\text { sintase) }\end{array}$ & (Filipov, 2000) \\
\hline B. sacchari LFM1039 & B. sacchari LFM344 recombinante com pBBR1MCS-2 vazio & Este trabalho \\
\hline P. putida LFM 046 & $\begin{array}{l}\text { Linhagem selvagem produtora de } \mathrm{PHA}_{\mathrm{MCL}} \text { isolada a partir de solo de } \\
\text { canavial }\end{array}$ & $\begin{array}{l}\text { (Gomez et al., } \\
\text { 1996) }\end{array}$ \\
\hline E. coli $\mathrm{S} 17-1436$ & Genes recA e tra do plasmídio RP4 integrados ao cromossomo & $\begin{array}{l}\text { (Simon, } \\
\text { Priefer e } \\
\text { Pühler, 1983) }\end{array}$ \\
\hline
\end{tabular}

E. coli S17-1 1223

E. coli S17-1 abrigando pBBR1MCS2 contendo os genes phaCE de Allochromatium vinosum (atualmente Allochromatium vinosum) Este trabalho $\left(\right.$ phaCE $\mathrm{Cv}^{)}$

E. coli $\mathrm{S} 17-11224$

E. coli S17-1 abrigando pBBR1MCS2 contendo os genes phaCE de

Thiocapsa pfennigii (phaCE $\left.E_{\mathrm{T}}\right)$

Este trabalho

P. putida LFM $1213 \quad P$. putida LFM046 abrigando o plasmídio pBBr1MCS2 sem inserto Este trabalho

P. putida LFM $461 \quad$ Mutante de LFM046deficiente no acúmulo de PHA a partir de glicose e octanoato $\left(p h a C^{-}\right)$ 
P. putida LFM $1214 \quad P$. putida LFM0461 abrigando o plasmídio pBBr1MCS2 sem inserto Este trabalho

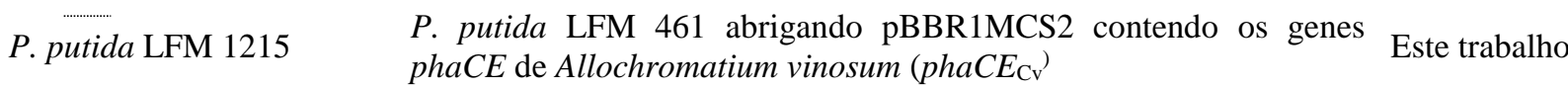

$\begin{array}{ll}\text { P. putida LFM } 1216 & \begin{array}{l}\text { P. putida LFM } 461 \text { abrigando pBBR1MCS2 contendo os genes } \\ \left.\text { phaCE de Thiocapsa pfennigii (phaCE } E_{\mathrm{Tp}}\right)\end{array}\end{array}$

$\begin{array}{ll}\text { P. putida LFM } 1216 & \begin{array}{l}\text { P. putida LFM } 461 \text { abrigando pBBR1MCS2 contendo os genes Este trabalho } \\ \text { phaCE de Thiocapsa pfennigii }\left(\text { phaCE } E_{\mathrm{Tp}}\right)\end{array}\end{array}$ $\begin{array}{ll}\text { B. sacchari LFM } 1217 & \begin{array}{l}\text { B. sacchari LFM344 abrigando pBBR1MCS2 contendo os genes Este trabalho } \\ \text { phaCE de Allochromatium vinosum (phaCE }{ }_{\mathrm{Cv}} \text { ) }\end{array}\end{array}$

B.sacchari LFM 344 abrigando pBBR1MCS2 contendo os genes Este trabalho phaCE de Thiocapsa pfennigii (phaCE $E_{\mathrm{Tp}}$ )

B.sacchari LFM 1218

F- mcrA $\Delta($ mrr-hsdRMS-mcrBC) Ф80lacZ $\Delta \mathrm{M} 15 \Delta$ lacX74 recA1

end $\mathrm{A} 1$ araD139 $\Delta$ (ara leu) 7697 galU galK rpsL nup $\mathrm{G} \lambda-$

Invitrogen

E. coli DH10B LFM 1219
E. coli DH10B LFM 1220
Linhagem hospedeira do plasmídeo pBAC/oriV contendo os (Galindo, fragmentos de interesse. $F^{-}$, Stp ${ }^{\mathrm{R}}$, PHA $^{-} \quad$ 2011)
E. coli DH5 $\alpha$ LFM 1221
F- Ф80lacZAM15 $\Delta($ lacZYA-argF) $\mathrm{U} 169$ recA1 endA1 hsdR17 (rK-, mK+) phoA supE44 $\lambda-$ thi-1 gyrA96 relA1
Invitrogen

E. coli DH5 $\alpha$ LFM 1222 E. coli DH5 $\alpha$ abrigando plasmídeo pBluescript SK ::B28+.PHA Este trabalho

\begin{tabular}{|c|c|c|}
\hline Spirulina sp & Cianobactéria & IOUSP* \\
\hline Synechococcus sp & Cianobactéria & IOUSP* \\
\hline pJM9131 & $\begin{array}{l}\text { Plasmídeo contendo os genes phaCAB de Ralstonia eutropha, } \mathrm{Kan}^{\mathrm{r}} \text {, } \\
\text { lacZ, } \mathrm{PHA}^{+}\end{array}$ & $\begin{array}{l}\text { (Kidwell, } \\
\text { Valentin e } \\
\text { Dennis, 1995) }\end{array}$ \\
\hline pBHR71 & $\begin{array}{l}\text { Plasmídeo contendo o gene phaC1 de Pseudomonas aeruginosa, } \\
\mathrm{Amp}^{\mathrm{r}} \text {, lacZ. } \mathrm{PHA}^{-}\end{array}$ & $\begin{array}{l}\text { (Langenbach, } \\
\text { Rehm } \\
\text { Steinbüchel, } \\
\text { 1997) }\end{array}$ \\
\hline pBAC/oriV & ori $\mathrm{V}, \operatorname{lac} \mathrm{Z} \alpha, \operatorname{par} \mathrm{A}, \operatorname{par} \mathrm{B}, \operatorname{par} \mathrm{C}, \operatorname{rep} \mathrm{E}, \mathrm{Cm}^{\mathrm{r}}$ & $\begin{array}{l}\text { (Wild, } \\
\text { Hradecna } \\
\text { Szybalski, } \\
\text { 2002) }\end{array}$ \\
\hline pBluescript SK::B28+ & $\begin{array}{l}\text { Plasmídeo contendo phaEC de Thiocapsa pfennigii. Amp }{ }^{\mathrm{r}} \text {, lacZ. } \\
\text { PHA }^{-}\end{array}$ & $\begin{array}{l}\text { (Liebergesell, } \\
\text { Rahalkar e } \\
\text { Steinbüchel, } \\
\text { 2000) }\end{array}$ \\
\hline
\end{tabular}


pBBR1MCS-2 ::phaCE $E_{\mathrm{Cv}}$ - pBBR1MCS-2 contendo os genes phaCE

pBBR1MCS-2 ::phaCE $E_{\mathrm{Cv}}$ de Allochromatium vinosum (atualmente Allochromatium vinosum) Este trabalho $\left(p h a C E_{\mathrm{Cv}}\right)^{\prime}$

pBBR1MCS-2 ::phaCE $E_{\mathrm{Tp}}$

pBBR1MCS-2 ::phaCE $E_{T p}$ - pBBRIMCS-2 abrigando pBBRIMCS2

contendo os genes phaCE de Thiocapsa pfennigii (phaCE $E_{T p}$ )

Este trabalho

$\begin{array}{ll}\text { pBBR1MCS-2 ::phaC } C_{B S} & \text { pBBR1MCS-2 ::pha } C_{B S}-\text { pBBR1MCS-2 contendo os genes phaC de } \\ \text { Burkholderia sacchari }\end{array}$

PHA $^{+}$: acúmulo de polihidroxialcanoatos, PHA : ausência de acúmulo do polímero, Kan ${ }^{\mathrm{R}}$ : resistência à canamicina, Amp ${ }^{\mathrm{r}}$ : Resistente à ampicilina, $\mathrm{Cm}^{\mathrm{r}}$ : Resistência ao cloranfenicol. * Coleção de Microrganismos Marinhos do Instituto Oceanográfico (IO-USP), coordenado pela Prof ${ }^{\text {a. }}$ Dr $^{\text {a. }}$ Sônia M. F. Gianesella

\subsection{Condições de cultivo}

As culturas microbianas de E. coli contendo os diferentes plasmídeos, assim como de Bacillus megaterium M.A 3.3 foram cultivadas em meio líquido e/ou sólido de Luria Bertani, contendo os antibióticos e a arabinose quando necessários (SAMBROOK et al., 1989). As linhagens de $E$. coli foram cultivadas a $37{ }^{\circ} \mathrm{C}$, sob agitação de $150-200$ rpm durante 20 horas e Bacillus megaterium M.A 3.3 foi cultivados a $30^{\circ} \mathrm{C}$, com agitação de 150-200 rpm durante 24 horas.

As culturas de Spirulina sp e Synechococcus sp foram cultivadas em meio F2 líquido (GUILLARD, 1962) a $18{ }^{\circ} \mathrm{C}$ durante 7 dias. 


\subsection{Meios de cultura}

Meio Luria Bertani - LB (Sambrook, Fritsch e Maniatis, 1989)

\begin{tabular}{ll}
\hline Componente & Concentração \\
\hline Triptona & $10 \mathrm{~g} / \mathrm{L}$ \\
\hline Extrato de levedura & $5 \mathrm{~g} / \mathrm{L}$ \\
Cloreto de Sódio & $10 \mathrm{~g} / \mathrm{L}$ \\
\hline
\end{tabular}

Para obtenção do meio sólido, foram adicionados de 15- 20 g/L de ágar.

Quando necessário, adicionou-se ampicilina 0,1g/L

Meio Luria Bertani com adição de Arabinose e Cloranfenicol - LBAC (Wild, Hradecna e Szybalski, 2002)

Tabela 3-Composição do meio LBAC

\begin{tabular}{ll}
\hline Componente & Concentração \\
\hline Triptona & $10 \mathrm{~g} / \mathrm{L}$ \\
\hline Extrato de levedura & $5 \mathrm{~g} / \mathrm{L}$ \\
Cloreto de Sódio & $10 \mathrm{~g} / \mathrm{L}$ \\
\hline Arabinose & $2 \mathrm{~g} / \mathrm{L}$ \\
Cloranfenicol & $0,0125 \mathrm{~g} / \mathrm{L}$ \\
\hline
\end{tabular}

Para obtenção do meio sólido, foram adicionados de 15- 20 g/L de ágar.

Meio F2

Tabela 4-Composição do meio F2

\begin{tabular}{llll}
\hline Componente & Solução Stock & Quantidade & Concentração final \\
\hline $\mathrm{NaNO}_{3}$ & $75 \mathrm{~g} / \mathrm{L} \mathrm{dH} \mathrm{dH}_{2} \mathrm{O}$ & $1 \mathrm{~mL}$ & $8.82 \times 10^{-4} \mathrm{M}$ \\
$\mathrm{NaH}_{2} \mathrm{PO}_{4} \mathrm{H}_{2} \mathrm{O}$ & $5 \mathrm{~g} / \mathrm{L} \mathrm{dH} \mathrm{dH}_{2} \mathrm{O}$ & $1 \mathrm{~mL}$ & $3.62 \times 10^{-5} \mathrm{M}$ \\
$\mathrm{Na}_{2} \mathrm{SiO}_{3} 9 \mathrm{H}_{2} \mathrm{O}$ & $30 \mathrm{~g} / \mathrm{L} \mathrm{dH_{2 } \mathrm { O }}$ & $1 \mathrm{~mL}$ & $1.06 \times 10^{-4} \mathrm{M}$ \\
$\begin{array}{l}\text { Elementos } \\
\text { (metal) }\end{array}$ & $1 \mathrm{~mL}$ & --- \\
Solução de vitaminas & & & \\
\hline
\end{tabular}


Elemento traço (metal)

Tabela 5-Composição da solução de elemento traço contido no meio F2

\begin{tabular}{llll}
\hline Componente & Solução de estoque & Quantidade & Concentração final \\
\hline $\mathrm{FeCl}_{3} 6 \mathrm{H}_{2} \mathrm{O}$ & --- & $3.15 \mathrm{~g}$ & $1.17 \times 10^{-5} \mathrm{M}$ \\
$\mathrm{Na}_{2} \mathrm{EDTA}_{2} \mathrm{H}_{2} \mathrm{O}$ & --- & $4.36 \mathrm{~g}$ & $1.17 \times 10^{-5} \mathrm{M}$ \\
$\mathrm{CuSO}_{4} 5 \mathrm{H}_{2} \mathrm{O}$ & $9.8 \mathrm{~g} / \mathrm{L} \mathrm{dH} \mathrm{H}_{2} \mathrm{O}$ & $1 \mathrm{~mL}$ & $3.93 \times 10^{-8} \mathrm{M}$ \\
$\mathrm{Na}_{2} \mathrm{MoO}_{4} 2 \mathrm{H}_{2} \mathrm{O}$ & $6.3 \mathrm{~g} / \mathrm{L} \mathrm{dH} \mathrm{dH}_{2} \mathrm{O}$ & $1 \mathrm{~mL}$ & $2.60 \times 10^{-8} \mathrm{M}$ \\
$\mathrm{ZnSO}_{4} 7 \mathrm{H}_{2} \mathrm{O}$ & $22.0 \mathrm{~g} / \mathrm{L} \mathrm{dH}_{2} \mathrm{O}$ & $1 \mathrm{~mL}$ & $7.65 \times 10^{-8} \mathrm{M}$ \\
$\mathrm{CoCl}_{2} 6 \mathrm{H}_{2} \mathrm{O}$ & $10.0 \mathrm{~g} / \mathrm{L} \mathrm{dH} \mathrm{dH}_{2} \mathrm{O}$ & $1 \mathrm{~mL}$ & $4.20 \times 10^{-8} \mathrm{M}$ \\
$\mathrm{MnCl}_{2} 4 \mathrm{H}_{2} \mathrm{O}$ & $180.0 \mathrm{~g} / \mathrm{L} \mathrm{dH} \mathrm{dH}_{2} \mathrm{O}$ & $1 \mathrm{~mL}$ & $9.10 \times 10^{-7} \mathrm{M}$ \\
\hline
\end{tabular}

Solução de vitaminas

Tabela 6-Composição da solução de vitaminas contida no meio F2

\begin{tabular}{llll}
\hline Componente & Solução stock & Quantidade & Concentração final \\
\hline tiamina $\mathrm{HCl}\left(\right.$ vit. $\left.\mathrm{B}_{1}\right)$ & --- & $200 \mathrm{mg}$ & $2.96 \times 10^{-7} \mathrm{M}$ \\
biotina (vit. H) & $0.1 \mathrm{~g} / \mathrm{L} \mathrm{dH}_{2} \mathrm{O}$ & $10 \mathrm{~mL}$ & $2.05 \times 10^{-9} \mathrm{M}$ \\
cianocobalamina (vit. $\left.\mathrm{B}_{12}\right)$ & $1.0 \mathrm{~g} / \mathrm{L} \mathrm{dH}_{2} \mathrm{O}$ & $1 \mathrm{~mL}$ & $10^{-10} \mathrm{M}$ \\
\hline
\end{tabular}

\subsection{Recuperação dos clones da biblioteca metagenômica}

A biblioteca metagenômica foi construída (MASSINI, 2004) a partir da obtenção do DNA total de amostras de solo de Mata e posterior digestão com a enzima HindIII. Após a otimização das condições de digestão, o DNA foi ligado com o vetor pBAC/oriV ( 8kb). O resultado da ligação foi inserido por transformação química, em células receptoras $E$. coli DH10B e semeadas em meio LBAC e incubado a $37^{\circ} \mathrm{C}$, gerando cerca de 5000 clones. As células transformantes foram transferidas para meio de cultura liquido em placas de polipropileno de 96 poços (Placas de ELISA) e crescidas em $150 \mu \mathrm{l}$ de meio LBAC, a $37{ }^{\circ} \mathrm{C}$ por 16 horas e em seguida foram adicionados $50 \mu \mathrm{l}$ de glicerol a $60 \%$ em cada poço para preservação das células, sendo finalmente acondicionadas à temperatura de $-80{ }^{\circ} \mathrm{C}$.

Desses 5000 clones, foram obtidos um total de 390 que foram positivos para algum dos quatro tipos de PHA sintase, detectada por PCR (GALINDO, 2011). Os 390 clones positivos da biblioteca metagenômica foram previamente removidos do freezer $-80{ }^{\circ} \mathrm{C}$ e descongelados em banho de gelo por aproximadamente 5 minutos antes de serem recuperados 
em novo meio. Novas placas de polipropileno de 96 poços foram preenchidas com $150 \mu 1$ de meio LBAC. Para transferir as culturas para novo meio, foi utilizado um carimbo de 96 dentes metálicos, previamente esterilizado em autoclave e sendo flambado após 2 minutos em álcool .Posteriormente, as culturas foram incubadas a $37{ }^{\circ} \mathrm{C}$ durante 16 horas. Após este período, foi avaliado o crescimento dos clones em cada uma das placas e foram feitas duas novas cópias, às quais após o período de cultivo foram adicionados $50 \mu \mathrm{l}$ de glicerol ao $60 \%$ a cada um dos poços para a preservação das células, sendo acondicionadas à temperatura de $-80^{\circ} \mathrm{C}$.

\subsection{Manipulação do DNA}

\subsubsection{Extração plasmidial}

Após a confirmação do crescimento dos clones, os mesmos foram inoculados separadamente em erlenmeyers de $250 \mathrm{~mL}$, contendo $50 \mathrm{~mL}$ de meio LBAC líquido e foram mantidos a $37{ }^{\circ} \mathrm{C}$ durante 18 horas. A extração plasmidial foi feita com o QIAprep Spin Miniprep Kit (QIAGEN),São Paulo, SP, Brasil, de acordo com as instruções do fabricante.

\subsubsection{Quantificação dos plasmídeos}

Após a extração plasmidial, as amostras foram quantificadas em NanoDrop 2000.

\subsubsection{Confirmação dos clones positivos}

Os clones positivos obtidos anteriormente (GALINDO, 2011) foram testados novamente por PCR e os oligonucleotídeos utilizados na reação, estão listados na tabela 6.As reação de PCR, foram realizadas utilizando-se os plasmídeos como DNA molde. Todos os oligos foram testados para todos os microrganismos controle, para detectar possíveis pareamentos de mais de um iniciador para um mesmo microrganismo controle. Os testes foram realizados com o material genético dos plasmídeos pJM9131, pBHR71 e Bacillus megaterium. M.A. 3.3. 
Tabela 7-Oligonucleotídeos empregados na confirmação da presença dos genes phaC.

\begin{tabular}{|c|c|c|c|c|}
\hline Nome & $\begin{array}{l}\text { Seqüência } \\
5^{\prime} \rightarrow 3^{\prime}\end{array}$ & $\begin{array}{l}\text { Classe PHA } \\
\text { sintase }\end{array}$ & $\begin{array}{l}\text { Tamanho } \\
\text { amplicon }\end{array}$ & Referência \\
\hline phaCF1 & ATCAACAARTWCTACRTCYTSGACCT & I & $\sim 496 \mathrm{pb}$ & (Sheu, Wang \\
\hline phaCR4 & AGGTAGTTGTYGACSMRTAGKTCCA & & & e Lee, 2000) \\
\hline I-179L(a) & ACAGATCAACAAGTTCTACATCTTCGAN & II & $\sim 540 \mathrm{pb}$ & (Solaiman, \\
\hline I-179R(a) & $\begin{array}{l}\text { GGTGTTGTCGTTGTTCCAGTAGAGGATG } \\
\text { TN }\end{array}$ & & & $\begin{array}{l}\text { Ashby e } \\
\text { Foglia, 2000; } \\
\text { Solaiman, } \\
\text { 2002) }\end{array}$ \\
\hline Haphapcr1 & $\begin{array}{l}\text { GTTTTAATCGATTACGCNYTNGTNAAYM } \\
\text { GNCCNTAYATG }\end{array}$ & III & $\sim 600 \mathrm{pb}$ & $\begin{array}{l}\text { (Hai, Hein e } \\
\text { Steinbüchel, }\end{array}$ \\
\hline Haphapcr2 & $\begin{array}{l}\text { CGGGACTATRAADATCCAYTTYTCCATN } \\
\text { CKTAGAAAGTT }\end{array}$ & & & 2001) \\
\hline $\mathbf{P 1}$ & ATNGAYTGGGGNTAYCCN & III & $\sim 536 \mathrm{pb}$ & (Hai \\
\hline $\mathbf{P 2}$ & RAADATCCAYTTYTCCAT & & & al., 2004) \\
\hline phaC3F & GTYTACGCCCTGGTVAAYC & III & $\sim 574 \mathrm{pb}$ & (Galindo \\
\hline phaC3R & KGAAYTGRCGGWARGTYTCS & & & Rozo, 2011) \\
\hline phaE3F & GCVRASMCYKTSGCCWAMAY & III & $\sim 563 \mathrm{pb}$ & (Galindo \\
\hline phaE3R & YCMDKRCDYYSAGRTTRTTYTYK & & & Rozo, 2011) \\
\hline B1F & AACTCCTGGGCTTGAAGACA & IV & $\sim 590 \mathrm{pb}$ & (Shamala et \\
\hline B1R & TCGCAATATGATCACGGCTA & & & al., 2003) \\
\hline
\end{tabular}

Fonte : (Galindo Rozo, 2011) Modificado

As reações de PCR foram realizadas em termociclador (Mastercycler Gradient, marca Eppendorf), adotando as seguintes condições:

Para um volume de $5 \mu \mathrm{L}$ de reação:

PCR GoTaq® Green Master Mix (Promega, USA)*

$3,0 \mu \mathrm{L}$

Iniciador foward $(10 \mu \mathrm{M})$

$0,5 \mu \mathrm{L}$

Iniciador reverse $(10 \mu \mathrm{M})$

$0,5 \mu \mathrm{L}$

DNA $(<250 \mathrm{ng} / \mu \mathrm{L})$

$0,5 \mu \mathrm{L}$

Água livre de nuclease

$0,25 \mu \mathrm{L}$

Dimetilsulfóxido (DMSO) (Merck)

$0.25 \mu \mathrm{L}$ 
* 50U/mL Taq DNA polimerase, $400 \mu \mathrm{M}$ de cada dATP, dGTP, dCTP, dTTP, 3mM de $\mathrm{MgCl} 2$

As reações de amplificação dos oligos para classe I,II e IV foram realizadas a uma temperatura inicial de desnaturação de $94{ }^{\circ} \mathrm{C}$ por 2 minutos, e subseqüentes ciclos de desnaturação a $94{ }^{\circ} \mathrm{C}$ por 1 minuto, anelamento a $58{ }^{\circ} \mathrm{C}$ por 2 minutos e extensão a $72{ }^{\circ} \mathrm{C}$ por 3 minutos, este ciclo foi repetido 35 vezes e incubação final a $4{ }^{\circ} \mathrm{C}$. A reação dos oligos para a classe III foi feita nas mesmas condições, mas com o anelamento a $52,2^{\circ} \mathrm{C}$.

\subsubsection{Digestão dos clones com enzimas de restrição}

Os DNAs plasmidiais previamente extraídos foram digeridos com enzimas de restrição do tipo FastDigest ${ }^{\circledR}$ (Fermentas Life Sciences), com volume final de $20 \mu \mathrm{L}$. As reações de digestão ocorreram de acordo com as orientações do fabricante, seguindo as concentrações, temperatura e tempo de incubação, específicos de cada enzima.

\subsubsection{Visualização do DNA}

Para visualização e análise do DNA provenientes de digestões, extrações e produtos de PCR foram realizadas corridas eletroforéticas em géis de agarose elaborados na concentração de $0,8 \%(\mathrm{~m} / \mathrm{v})$. A solução TAE foi utilizada para dissolver a agarose, bem como o tampão de corrida (SAMBROOK et al., 1989)

\section{Solução TAE}

Tris-base (hidroximetil aminometano)

$242 \mathrm{~g}$

Ácido acético glacial

$57,1 \mathrm{~mL}$

EDTA de cálcio e sódio $0,5 \mathrm{M}$

$100 \mathrm{~mL}$

$\mathrm{H}_{2} \mathrm{O}$ q.s.p

$1000 \mathrm{~mL}$

A agarose dissolvida em TAE foi levada ao micro ondas por 1 minuto e em seguida adicionou-se $S Y B R^{\circledR}$ Safe na proporção de $1 \mu \mathrm{L}$ de SYBR para $10 \mathrm{~mL}$ de agarose diluída em TAE. Após a solidificação do gel, as amostras de DNA foram aplicadas e estes submetidos a corridas eletroforéticas de $60-120 \mathrm{~V}, 80 \mathrm{~mA}, 80 \mathrm{~W}$ por 1 hora. Ao final da corrida eletroforética, os fragmentos de DNA puderam ser observados sob luz UV (254nm) em transiluminador (Multidoc-It Digital Imaging system UV transilluminator, USA). Foi 
aplicado no primeiro poço da canaleta do gel, o marcador de tamanho de fragmento de DNA $1 \mathrm{~kb}$ plus fermentas para orientação na seleção dos fragmentos obtidos.

\subsubsection{Eletroporação}

Células eletrocompetentes da linhagem E. coli DH5 $\alpha$ foram preparadas conforme descrito por Ausubel,1992 (AUSUBEL et al., 1992). Inoculou-se uma colônia da bactéria em meio LB líquido durante 16 horas a $37{ }^{\circ} \mathrm{C}$ em agitador rotativo. Após a incubação, a densidade ótica (D.O.610nm) foi determinada e um volume adequado de meio LB foi adicionado ao cultivo, de modo a se obter D.O.610nm inicial de 0,1 unidades de absorbância e $500 \mathrm{~mL}$ de cultura final. O cultivo foi então incubado a $37{ }^{\circ} \mathrm{C}$ em agitador rotativo e medições de D.O. foram realizadas, até atingir D.O.610 $\mathrm{nm}=0,5$.

Atingida a D.O. adequada, transferiu-se a cultura para tubos de centrifuga préresfriados, mantida em banho de gelo (15 min), e centrifugadas (15 min, $8000 \mathrm{rpm}, 4{ }^{\circ} \mathrm{C}$ ). Descartando o sobrenadante, as células foram ressuspensas em $100 \mathrm{~mL}$ de água milli-Q estéril e gelada, e centrifugadas nas mesmas condições descritas anteriormente. Esse procedimento foi repetido duas vezes e na terceira repetição, a água milli-Q estéril foi substituída por glicerol $10 \%$. O sobrenadante foi mais uma vez desprezado e as células foram ressuspensas em 1,0 mL de glicerol 10\% gelado, distribuídas em alíquotas de $40 \mu \mathrm{L}$ e conservadas em freezer $-80{ }^{\circ} \mathrm{C}$.

Para transformação das células eletrocompetentes foi adicionado 1uL do plasmídeo de interesse, à alíquota de células eletrocompentes. A mistura foi então transferida para cubetas de eletroporação de $0,2 \mathrm{~cm}$, previamente resfriadas. As células foram submetidas a pulsos de $2500 \mathrm{~V}$, capacitância de $25 \mu \mathrm{F}$ e resistência de $200 \Omega$ para a eletroporação. Adicionou-se 1,0 $\mathrm{mL}$ de meio LB às células, que foram incubadas a $37^{\circ} \mathrm{C}$. Posteriormente, as células foram semeadas em meio LB sólido contendo o ampicilina e incubadas a $37{ }^{\circ} \mathrm{C}$, por 24 horas

\subsubsection{PCR de colônia}

A PCR de colônia foi utilizado com duas finalidades: para selecionar os clones resultantes da eletroporação que, e para avaliar se as cianobactérias Spirulina sp $e$ Synechococcus sp possuíam o gene phaC. Em ambos os casos, utilizou-se os oligos que amplificam phaC de classe III. 
Primeiramente, as colônias isoladas são colocadas em microtubos contendo $150 \mu \mathrm{L}$ de água livre de nuclease, previamente esterilizada em autoclave, com o auxilio de ponteiras ou palitos estéreis. A mistura foi mantida por 10 minutos a $95^{\circ} \mathrm{C}$ (Pandey et al., 2007). Posteriormente, as amostras foram centrifugadas por 3 minutos a $13000 \mathrm{rpm}$ e em seguida levadas ao freezer, onde ficavam pelo menos por 4 horas, antes da utilização. Para fazer a reação do PCR, $2 \mu \mathrm{L}$ do sobrenadante foram adicionados à reação, como listado abaixo:

Para um volume de $10 \mu \mathrm{L}$ de reação:

PCR GoTaq® Green Master Mix (Promega, USA)* $\quad 6,0 \mu \mathrm{L}$

Iniciador foward $(10 \mu \mathrm{M}) \quad 1,0 \mu \mathrm{L}$

Iniciador reverse $(10 \mu \mathrm{M}) \quad 1,0 \mu \mathrm{L}$

DNA(sobrenadante) $\quad 2,0 \mu \mathrm{L}$

\subsubsection{Purificação dos produtos de PCR obtidos}

Para o isolamento e a purificação do produto de interesse de cada reação de PCR após a separação e visualização dos fragmentos por corrida eletroforética em gel de agarose, foram utilizados dois tipos de kits dependendo da presença de bandas inespecíficas. Para o isolamento a partir do gel de agarose, quando havia presença de bandas inespecíficas, foi utilizado o QIAquick Gel Extraction kit (QIAGEN, USA) e para os produtos de PCR que só apresentavam o amplicon de interesse foi utilizado o QIAquick PCR purification kit (QIAGEN, USA), conforme instruções dos fabricantes.

\subsubsection{Reações de sequenciamento}

Após a purificação dos fragmentos amplificados, estes foram utilizados para a reação de seqüenciamento no Centro de Estudos do Genoma Humano - USP, com o ABI 3730 DNA Analyser (Applied Biosystems, USA). As reações de sequenciamento foram feitas utilizando o BigDye ${ }^{\circledR}$ Terminator v3.1 Cycle Sequencing Kit.

\subsubsection{Análise das sequências}

As sequências consenso foram obtidas pelo software Pregapep e GAP oferecidos pelo programa Staden Package (BONFIELD; STADEN, 1996) e posteriormente analisadas 
empregando a ferramenta blastn encontrada no programa do National Center for Biotechnology Information (NCBI), buscando o resultado de alinhamento com o gene phaC das diferentes classes.

\subsection{Construção dos recombinantes}

Nesta etapa foram feitos experimentos para expressar os genes phaCE de Allochromatium vinosum presente no plasmídeo pds37, de phaCE de Thiocapsa pfennigii abrigado no plasmídeo pBluescript $\mathrm{SK}^{-}: \mathrm{B} 28+$ e phaC de Burkholderia sacchari, em uma linhagem Burkholderia sacchari LFM 344 (FILIPOV, 2000) e Pseudomonas sp. LFM 461(GOMEZ, 2000a), ambas PHA negativas.

Para clonagem de phaCE de Thiocapsa pfennigii, o plasmídeo pBluescript $\mathrm{SK}^{-}$ ::B28+ e foi digerido com a enzima de restrição BamHI para a remoção do inserto. Além disso, foram sintetizados um par de primers com o intuito de amplificar o gene a ser clonado (tabela 7). O inserto removido foi ligado, utilizando-se a enzima T4 ligase, em um plasmídeo pBBR2MCS-1 previamente digerido com BamHI. Os plasmídeos com inserto foram inseridos por eletroporação para E. coli DH10B, e as colônias foram selecionadas por alphacomplementação. Após a seleção das colônias, os plasmídeos foram extraídos como descrito no item 5.5.1. e inseridos por eletroporação nas linhagens LFM 461 e LFM 344.

Para a clonagem dos genes phaCE de Allochromatium vinosum também utilizaram-se dois procedimentos distintos: a digestão do plasmídeo pds37 com as enzimas EcoRI e $P v \mathrm{uI}$ para a remoção do inserto e a síntese de primers que flanqueiam o gene (tabela 7). O primer foi testado em diversas temperaturas de anelamento para a padronização da reação de PCR. Após a obtenção da amplificação do gene com a utilização dos primers desenhados, o amplicon obtido através da reação de PCR (tabela 8) foi sequenciado e após a confirmação da sequência o mesmo foi digerido com as enzimas de restrição XhoI e EcoRI, purificado e ligado, utilizando uma enzima T4 ligase, em um pBBR2MCS-1 previamente digerido com XhoI e EcoRI. O plasmídeo com o inserto foi inserido por eletroporação em células eletrocompetentes de E.coli DH10B e as células foram selecionadas por alfa complementação. Para a confirmação dos clones recombinantes, realizou-se um PCR de colônia utilizando-se os primers descritos acima.

Já na clonagem do gene phaC de Burkholderia sacchari foi sintetizado um primer que flanqueia o gene $p h a C$, para que o gene a ser clonado fosse amplificado em sua totalidade 
Tabela 8-Sequência dos primers que flanqueiam phaCE de Allochromatium vinosum, Thiocapsa pfennigii e Burkholderia sacchari respectivamente

\begin{tabular}{llll} 
Nome & $\begin{array}{l}\text { Seqüência } \\
\mathbf{5}^{\prime} \rightarrow \mathbf{3}^{\prime}\end{array}$ & $\begin{array}{l}\text { Tamanho } \\
\text { amplicon }\end{array}$ & Referência \\
\hline $\begin{array}{l}\text { PFEcoRI } \\
\text { phaCE }\end{array}$ & CGGCCGGAATTCATCCAGGGCCACTATCTCCAAC & $\sim 3000 \mathrm{pb}$ & Presente \\
PRXhoI & & trabalho \\
phaCE & & Presente \\
phaECThioA & ACTCATGGGCCCTCGAGGACGCCTCGCGAAGGCT & $\sim 2600 \mathrm{pb}$ & Presente \\
paPF & CTAG & trabalho \\
phaECThioEc & CTAGTTGAATTCTCAGCCGCGTTCGTTCAGCCAG & Presente \\
oPR & C & trabalho \\
& & & Presente \\
phaCBSF & GTAAGTGGATCCGTACTTCATGCGATTCAAATCA & $\sim 2000 \mathrm{pb}$ & trabalho \\
& G & & \\
\hline
\end{tabular}

Tabela 9-Condições de PCR do primer PFEcoRI phaCE/ PRXhoI phaCE

\begin{tabular}{ccc}
\hline Etapa & Temperatura & Tempo \\
\hline Temperatura de Lid & $104^{\circ} \mathrm{C}$ & - \\
\hline Ativação da enzima & $95^{\circ}$ & 5 minutos \\
\hline Desnaturação & $94^{\circ}$ & 15 segundos \\
\hline Anelamento & $68.1^{\circ} \mathrm{C}$ & 1 minuto \\
\hline Extensão & $68^{\circ} \mathrm{C}$ & 6 minutos \\
\hline Extensão Final & $72^{\circ} \mathrm{C}$ & 10 minutos \\
\hline Hold & $4^{\circ} \mathrm{C}$ & - \\
\hline
\end{tabular}

Tabela 10-Condições de PCR do primer phaCBSF/ phaCBSR

\begin{tabular}{ccc}
\hline Etapa & Temperatura & Tempo \\
\hline Temperatura de Lid & $104^{\circ} \mathrm{C}$ & - \\
\hline Ativação da enzima & $95^{\circ}$ & 5 minutos \\
\hline Desnaturação & $94^{\circ}$ & 15 segundos \\
\hline Anelamento & $56^{\circ} \mathrm{C}$ & 1 minuto \\
\hline Extensão & $72^{\circ} \mathrm{C}$ & 6 minutos \\
\hline Extensão Final & $72^{\circ} \mathrm{C}$ & 10 minutos \\
\hline Hold & $4^{\circ} \mathrm{C}$ & - \\
\hline
\end{tabular}




\subsection{Avaliação da capacidade dos recombinantes no acúmulo de PHA}

A avaliação qualitativa da capacidade de acúmulo de clones recombinantes obtidos foi feita pelo o método de coloração com Sudan Black B, como descrito previamente (SCHLEGEL, 1970).

Para avaliação quantitativa, as linhagens recombinantes de B. sacchari e $P$. putida foram inoculadas em LB líquido contendo canamicina e incubadas em agitador rotativo a 30 ${ }^{\circ} \mathrm{C}$ por 24 horas. Após esse período, $5 \mathrm{~mL}$ do inóculo foram depositados em meio mineral com glicose 10g/L e canamicina. Após 24 horas foram adicionados diferentes fontes de carbono: ácido hexanóico $1 \mathrm{~g} / \mathrm{L}$, ácido propiônico $1 \mathrm{~g} / \mathrm{L}$, ácido butírico $1 \mathrm{~g} / \mathrm{L}$, ácido valérico $1 \mathrm{~g} / \mathrm{L}$, ácido hexanóico $1 \mathrm{~g} / \mathrm{L}$, ácido heptanóico $1 \mathrm{~g} / \mathrm{L}$, ácido octanóico $1 \mathrm{~g} / \mathrm{L}$ e ácido nonanóico

$1 \mathrm{~g} / \mathrm{L}$. Posteriormente a cultura foi mantida em agitação por mais 48 horas. Foram retiradas amostras com 24 e 72 horas de cultivo para análises posteriores (determinação de biomassa e PHA). Para todos os ensaios foram realizados cultivos em triplicata, conforme previamente descritos por Gomez et al., 1996.

\subsubsection{Teor e composição do polímero}

Quantidade e composição de PHA: A quantidade e composição de PHA foram determinadas por cromatografia de fase gasosa de propil-ésteres (RIIS; MAI, 1988). Cerca de 10 a 15mg de células liofilizadas foram transferidas para tubos de vidro, aos quais foram adicionados $2 \mathrm{~mL}$ de uma solução de ácido clorídrico em propanol (1:4 v/v), $2 \mathrm{~mL}$ de 1,2dicloroetano e $100 \mu \mathrm{L}$ de uma solução de ácido benzóico (40g/L) em propanol. Os tubos foram submetidos a uma temperatura de $100^{\circ} \mathrm{C}$ por 3 horas. Após o resfriamento, foram adicionados aos tubos $4 \mathrm{~mL}$ de água destilada, agitando-os por 30 segundos. Após a separação da fase aquosa da fase orgânica, descartou-se a aquosa e a orgânica foi utilizada para a análise. A amostra foi analisada por cromatografia de fase gasosa de propil-ésteres (RIIS ; MAI, 1988). Foi utilizado cromatógrafo gasoso HP7890A Series GC System equipado com uma coluna HP-5 (5\% difenil-95\%dimetil-polisiloxane, comprimento 30m, diâmentro 320 mm, espessura do filme $0,25 \mu \mathrm{m})$. A análise foi conduzida nas seguintes condições: gás de arraste - Hélio (0,6 mL/ min); Temperatura do injetor: $250^{\circ} \mathrm{C}$; Temperatura do detector: 300 ${ }^{\circ} \mathrm{C}$; Sistema de detecção: ionização de chama (FID); Programa de temperaturas do forno: 100 ${ }^{\circ} \mathrm{C}$ por 3 minuto $(6 \mathrm{C} / \mathrm{min})$, elevação da temperatura até $180^{\circ} \mathrm{C}$ por 5 minutos $\left(6^{\circ} \mathrm{C} / \mathrm{min}\right)$ e até 
$240{ }^{\circ} \mathrm{C}$ por 1 minuto. Os propil-ésteres obtidos foram analisados por cromatografia gasosa (GOMEZ, 2000a).

\subsubsection{Massa seca celular (MSC)}

A biomassa foi determinada por gravimetria, centrifugando-se $10 \mathrm{~mL}$ do cultivo (10600 $\left.x \mathrm{~g}, 10 \mathrm{~min}, 4^{\circ} \mathrm{C}\right)$ e submetendo-o à liofilização.

\subsection{Determinação da concentração de ácidos orgânicos}

A concentração de ácidos orgânicos foi determinada por cromatografia gasosa (CG) após acidificação da amostra $(800 \mu \mathrm{L})$ com $200 \mu \mathrm{L}$ de solução contendo $\mathrm{HCl}(0,2 \mathrm{~mol} / \mathrm{L})$ e ácido butírico ou ácido acético $(4,8 \mathrm{~g} / \mathrm{L})$. Os ácidos orgânicos foram analisados em aparelho Agilent 7890A equipado com uma coluna capilar FFAP, após split das amostras (1:5). Hélio (3,0 $\mathrm{mL} / \mathrm{min})$ foi usado como gás de arraste. A temperatura do injetor e detector (FID) foi 250 ${ }^{\circ} \mathrm{C}$ e $300{ }^{\circ} \mathrm{C}$, respectivamente. A temperatura da coluna foi mantida a $130^{\circ} \mathrm{C}$ durante os primeiros 5 min. Então, a temperatura foi aumentada à razão de $10^{\circ} \mathrm{C} / \mathrm{min}$ até a temperatura final de $185^{\circ} \mathrm{C}$, a qual permaneceu por $1 \mathrm{~min}$. 


\section{RESULTADOS E DISCUSSÃO}

\section{$5.1 \quad$ Viabilidade dos clones}

Os 390 clones anteriormente confirmados como positivos para alguma das classes de PHA sintase (GALINDO, 2011) foram testados quanto a sua viabilidade. A tabela 7 mostra os clones que foram inviáveis, ou seja, que não apresentaram crescimento durante a recuperação da biblioteca metagenômica. Dos 390 clones que estavam mantidos em freezer $-80^{\circ} \mathrm{C}, 29$ foram inviáveis. A inviabilidade dos clones, pode ter sido causada pelo tempo em que ficou armazenado no freezer sem que houvesse subcultivos periódicos. Por outro lado, a preservação em freezer $-80{ }^{\circ} \mathrm{C}$ é comumente utilizada com sucesso para preservação de linhagens por períodos que podem chegar até 10 anos, dependendo da linhagem, pois subcultivos periódicos podem levar à seleção de clones que não representativos da população original (SILVA et al., 1992).

Tabela 11-Relação dos clones que não apresentaram viabilidade durante a recuperação da biblioteca metagenômica

\begin{tabular}{ll}
\hline Placa & Clones inviáveis \\
\hline 6 & H11 \\
\hline 9 & B3, A2, C10, E4, G1, D6, F7, A8, A9, A11 \\
23 & E6 \\
24 & D12 \\
25 & D12, E3, F9, E7 \\
27 & H1 \\
29 & D10 \\
34 & H1, E9 \\
37 & H12, F11 \\
\hline 38 & B9, C4, D6, A4, A3, E11 \\
\hline
\end{tabular}

\subsection{Avaliação dos clones positivos}

\subsubsection{Extração plasmidial}

Devido ao baixo rendimento nas extrações plasmidiais iniciais, cerca de $20 \mathrm{ng} / \mu \mathrm{L}$, foram feitos diversos testes para aumentar a concentração de plasmídeos obtidos. Foram 
alterados diversos parâmetros como: mudança dos lotes da arabinose e do antibiótico, aquecimento do tampão de eluição antes do uso e exclusão do buffer PB, que é opcional e indicado para cepas com atividade de endonuclease A. Nessa última condição o rendimento da extração plasmidial passaou de $20 \mathrm{ng} / \mu \mathrm{L}$ para $90-150 \mathrm{ng} / \mu \mathrm{L}$.A figura 6 mostra o gel de agarose com o resultado da extração de alguns clones, que permitiu a confirmação de que a extração dos plasmídeos foi bem sucedida. A corrida eletroforética em gel de agarose foi feita com os plasmídeos fechados, o que impossibilita avaliar o tamanho exato de cada um, entretanto o objetivo era avaliar o o rendimento da extração.

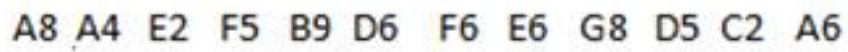

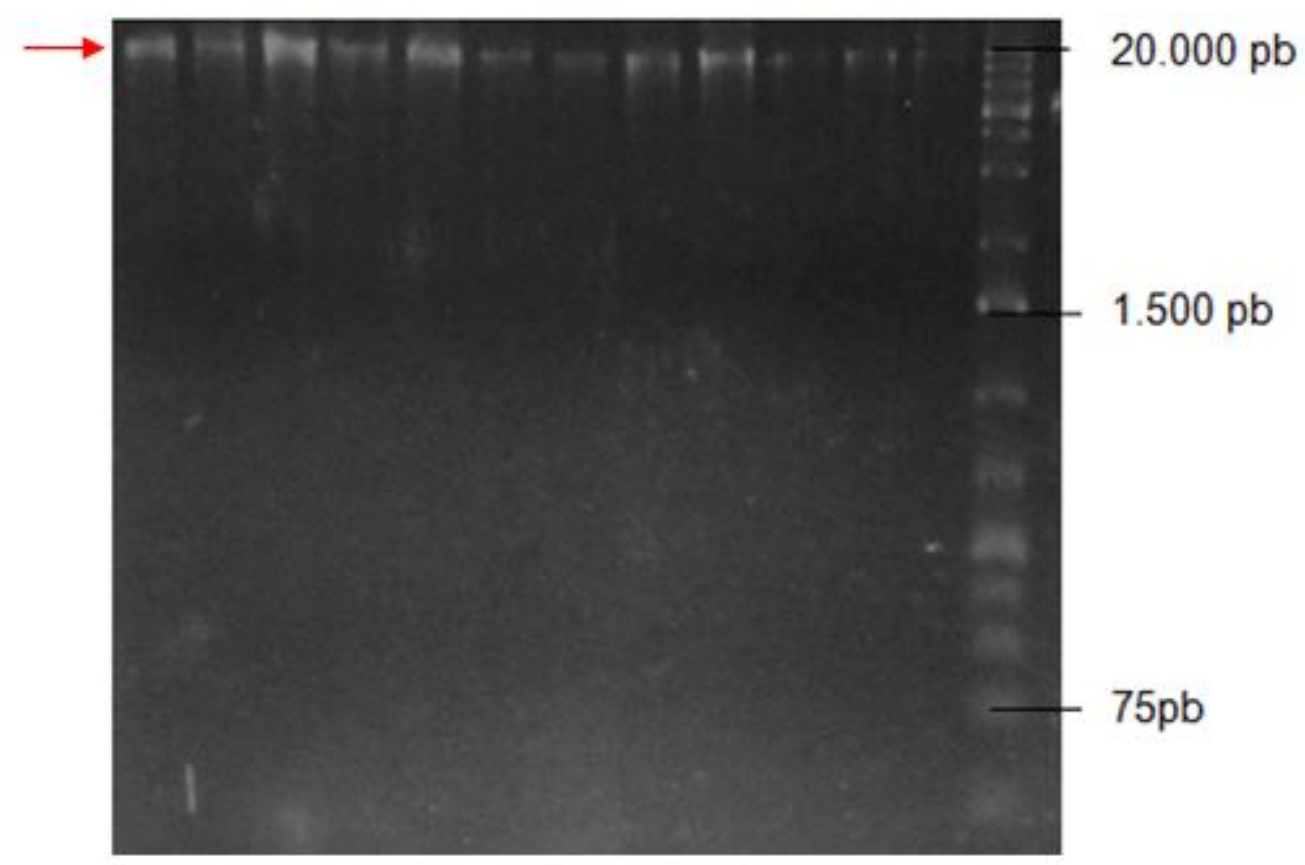

Figura 6- Perfil eletroforético em gel de agarose $0.8 \% \quad(\mathrm{p} / \mathrm{v})$, mostrando o resultado da extração plasmidial dos clones A8,A4,E2,F5,B9,D6,F6,E6,G8,D5,C2 E A6 da placa 23. A seta indica a presença dos plasmídeos, próximo ao tamanho de 20.000 pb.

\subsection{Experimento controle da amplificação}

Anteriormente ao início das amplificações para a busca dos genes alvo nos clones da biblioteca, realizou-se um teste com os controles de cada classe com os diferentes oligos, para avaliar a especificidade de cada um deles. Foram empregados como DNA molde os seguintes controles:

- O plasmídeo pJM9131 (KIDWELL;VALENTIN ;DENNIS, 1995), controle da amplificação do primer de classe I, que abriga o operon de síntese de P3HB de R. eutropha, 
foi testado para os primers phaCF1/phaCR4, I-179L (a)/I-179R(a) e B1F/B1R.Obteve-se um fragmento de aproximadamente $500 \mathrm{pb}$ (figura 8) apenas com o primer phaCF1/phaCR4, o que era esperado para esse par de oligos, que foram desenhados a partir do alinhamento que incluíam sequências da PHA sintase de classe I (SHEU; WANG; LEE, 2000);

- $\quad$ O plasmídeo pBHR71 (LANGENBACH; REHM; STEINBÜCHEL, 1997), controle positivo da classe II que abriga phaCl de Pseudomonas aeruginosa. Esse controle também foi testado com os primers phaCF1/phaCR4, I-179L (a)/I-179R(a) e B1F/B1R. Nesse caso obteve-se um amplicon de 500pb com phaCF1/phaCR4 e de 540 pb I-179L (a)/I-179R(a).

- $\quad$ DNA genômico de Bacillus megaterium. M.A. 3.3, que foi testado com os primers phaCF1/phaCR4, I-179L (a)/I-179R(a) e B1F/B1R e apresentou um amplicon de aproximadamente 590pb somente com a utilização dos primers B1F/B1R, que confirmou o tamanho esperado para esse par de oligos.Os resultados estão na Fig.7.

A amplificação de genes das classes I e II pelos primers phaCF1/phaCR4 já era esperada, uma vez que para desenhar esses primers, sequências de PHA sintases de classe I e II foram alinhadas para a obtenção das regiões conservadas (SHEU; WANG E; LEE, 2000). Dessa forma, o ideal é que sejam desenhados primers que sejam capazes de se anelarem apenas com sequências codificadoras de PHA sintase de classe I. Entretanto, vários testes já foram realizados tentando buscar um par de iniciadores universal apenas para classe I, mas os resultados indicaram que é preciso separar as sequências de classe I em grupos com maior similaridade entre si e desenhar os primers de acordo com os grupos (LÍCIO, 2011). Isso decorre do fato de que sequências, ainda que consideradas de classe I, envolvem genes de organismos de gêneros distintos (ao contrário de classes II e IV em que predominam espécies Pseudomonas e Bacillus, respectivamente). Uma vez que no presente trabalho, utilizou-se uma biblioteca metagenômica que possui DNA de diversas espécies diferentes, pareceu mais apropriado utilizar um par de primers mais generalista, mesmo que amplificassem inespecificamente as classes I e II.

Tendo em vista a ausência de controle positivo contendo DNA molde para os primers de classe III, foram solicitados ao laboratório do Prof. Steinbuchel (Munster, Alemanha) dois plasmídeos: o pBluescript $\mathrm{SK}^{*}: \mathrm{B} 28+$, que abriga phaEC de Thiocapsa pfennigii e o plasmídeo pds37, que abriga phaEC de Allochromatium vinosum (LIEBERGESELL et al., 1994; LIEBERGESELL; RAHALKAR; STEINBÜCHEL, 2000). Ambos os plasmídeos, chegaram recentemente ao laboratório e por essa razão, não foram incluídos nesse experimento. 


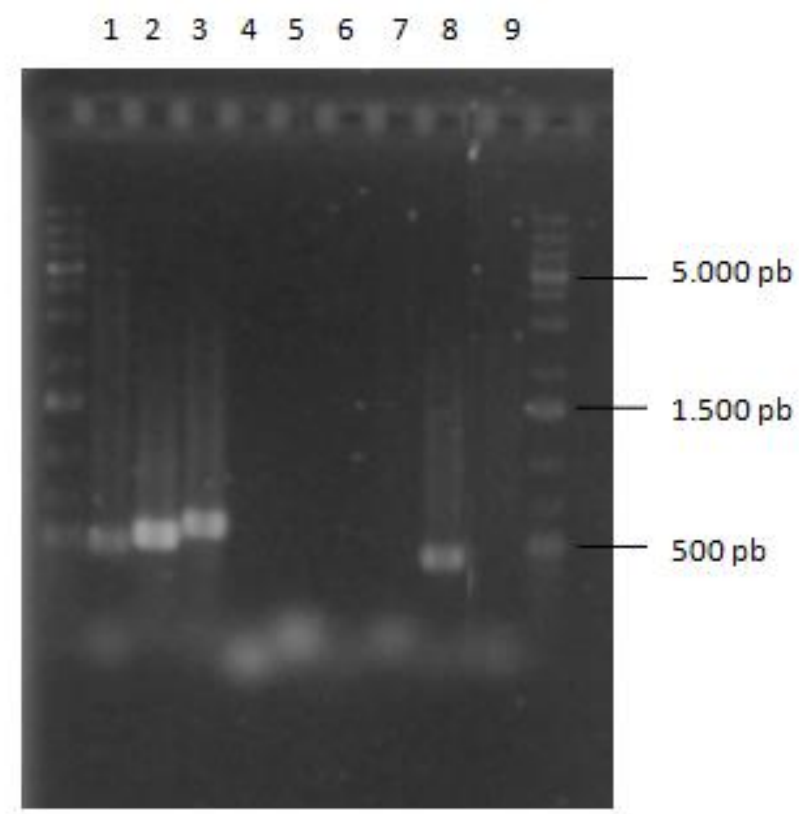

Figura 7-Perfil eletroforético em gel de agarose $0.8 \%$ (p/v) mostrando a amplificação obtida na reação de PCR pelo primer phaCF1/CR4 na presença de pJM9131(1) e pBHR71 (8) e a ausência de fragmentos quando DNA de B.megaterium foi utilizado como molde (9).A caneleta 2 mostra a amplificação obtida com os primers I-179L (a)/I-179R(a), tendo pBHR71 como molde.Esses primers também foram utilizados nas reações presentes na canaletas 4 e 7 , contendo como molde pJM9131 e B. megaterium respectivamente. Os primers $\mathrm{B} 1 \mathrm{~F} / \mathrm{B} 1 \mathrm{R}$ foram utilizados nas reações das canaletas 3,5 e 6 , tendo como DNA molde B.megaterium, pJM9131,e pBHR71 respectivamente.

A confirmação dos clones positivos começou com reações de PCR, utilizando-se como DNA molde, amostras dos clones positivos, que consistiam em lisados (células dos clones lisadas por fervura) que foram utilizados anteriormente (GALINDO, 2011) e estavam armazenados em freezer $-20^{\circ} \mathrm{C}$. As primeiras amplificações realizadas, foram as dos clones previamente detectados como positivos para a classe II (Figura 8 e 9), que como pode-se obervar vários foram confirmados como positivos. Entretanto, quando a PCR foi realizada com os clones positivos para a classe I, nenhum deles se confirmaram como positivo (figura 10 e 11). Tendo em vista que o clones já haviam sido confirmados anteriormente como positivos (Galindo, 2011), acreditou-se que o DNA dessas amostrar poderia ter sido degradado, devido ao longo período armazenado no freezer e optou-se por recuperar os clones que estavam armazenados em freezer $-80^{\circ} \mathrm{C}$, fazer a extração plasmidial e posteriormente as amplificações. 


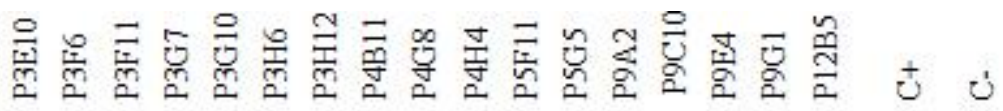

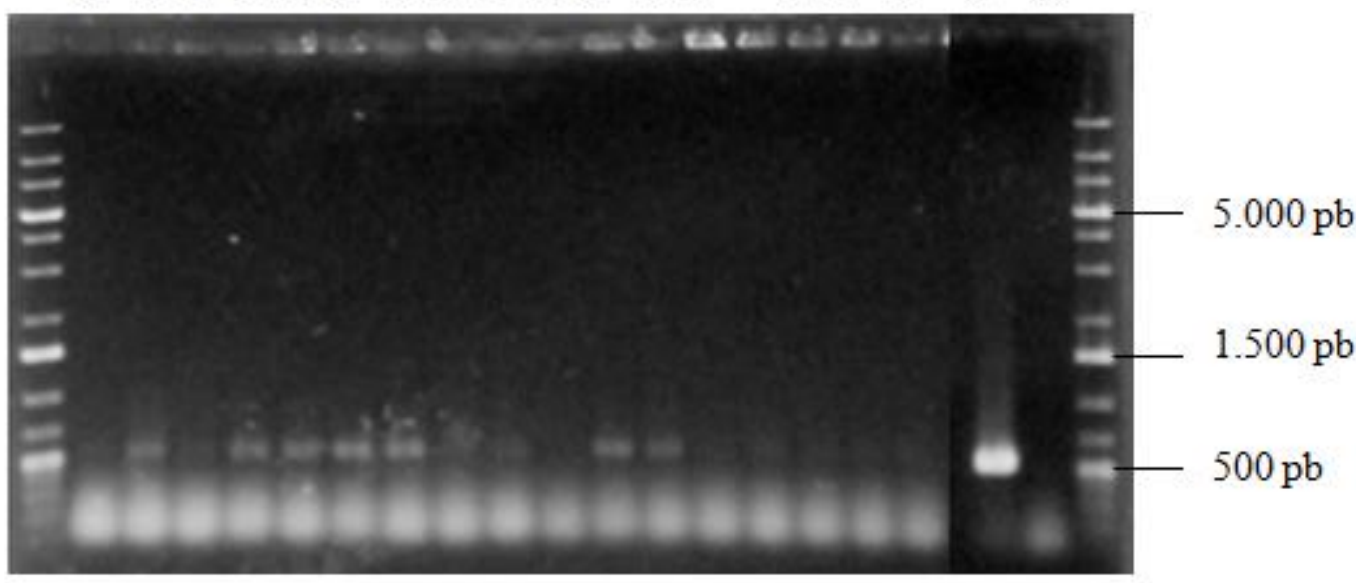

Figura 8-Perfil eletroforético em gel de agarose $0.8 \%$ (p/v) resultante da amplificação por PCR dos clones descritos acima, com o par de primer 179L (a)/I-179R(a).

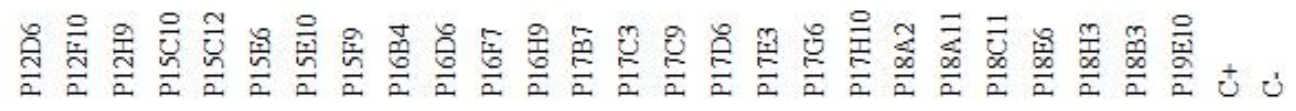

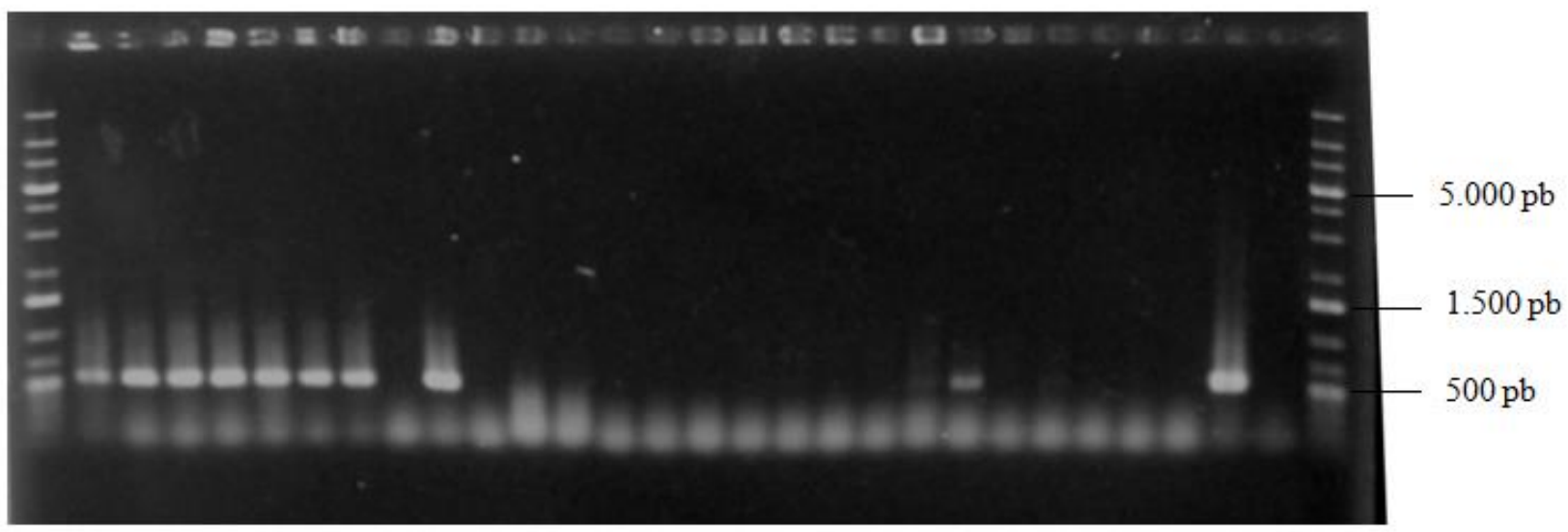

Figura 9-Perfil eletroforético em gel de agarose $0.8 \%$ (p/v) resultante da amplificação por PCR dos clones descritos acima com o par de primer 179L (a)/I-179R(a). 


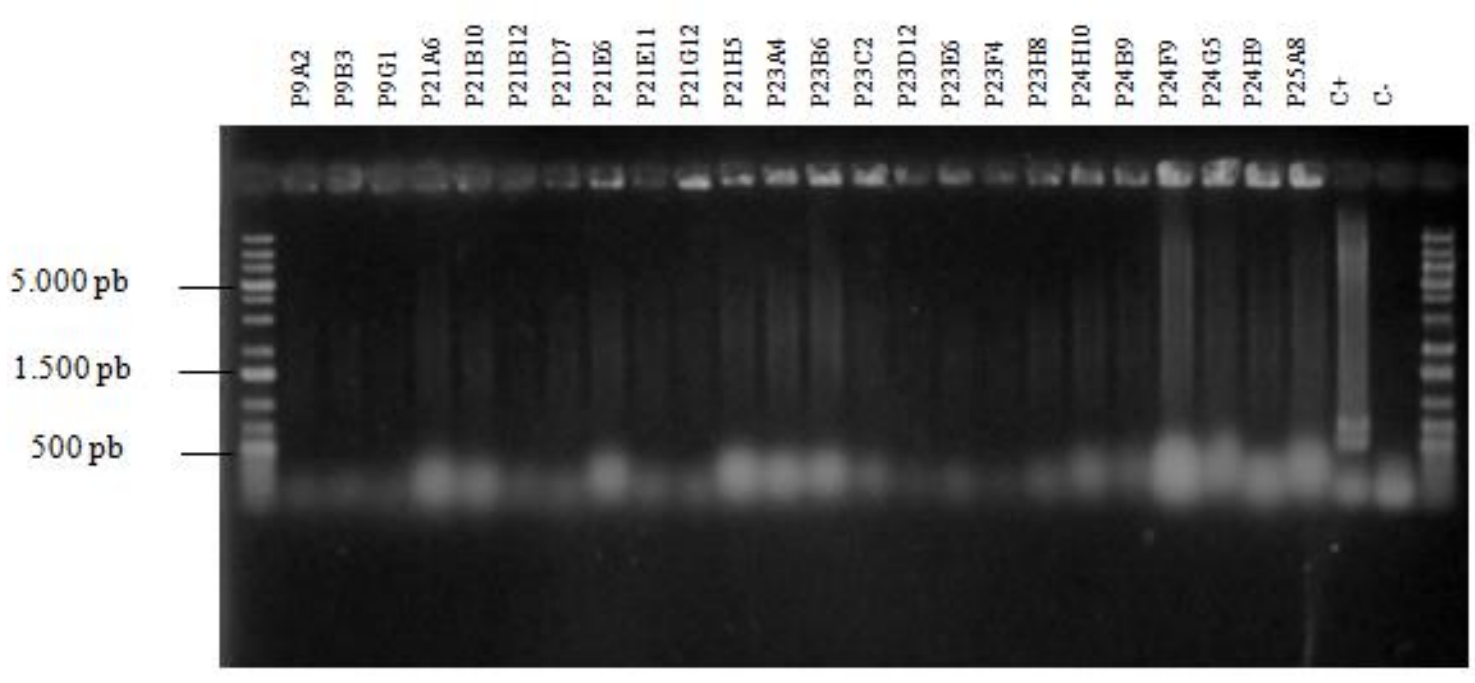

Figura 10-Perfil eletroforético em gel de agarose $0.8 \%(\mathrm{p} / \mathrm{v})$ resultante da amplificação por PCR dos clones descritos acima com o par de primer phaCF1/phaCR4.

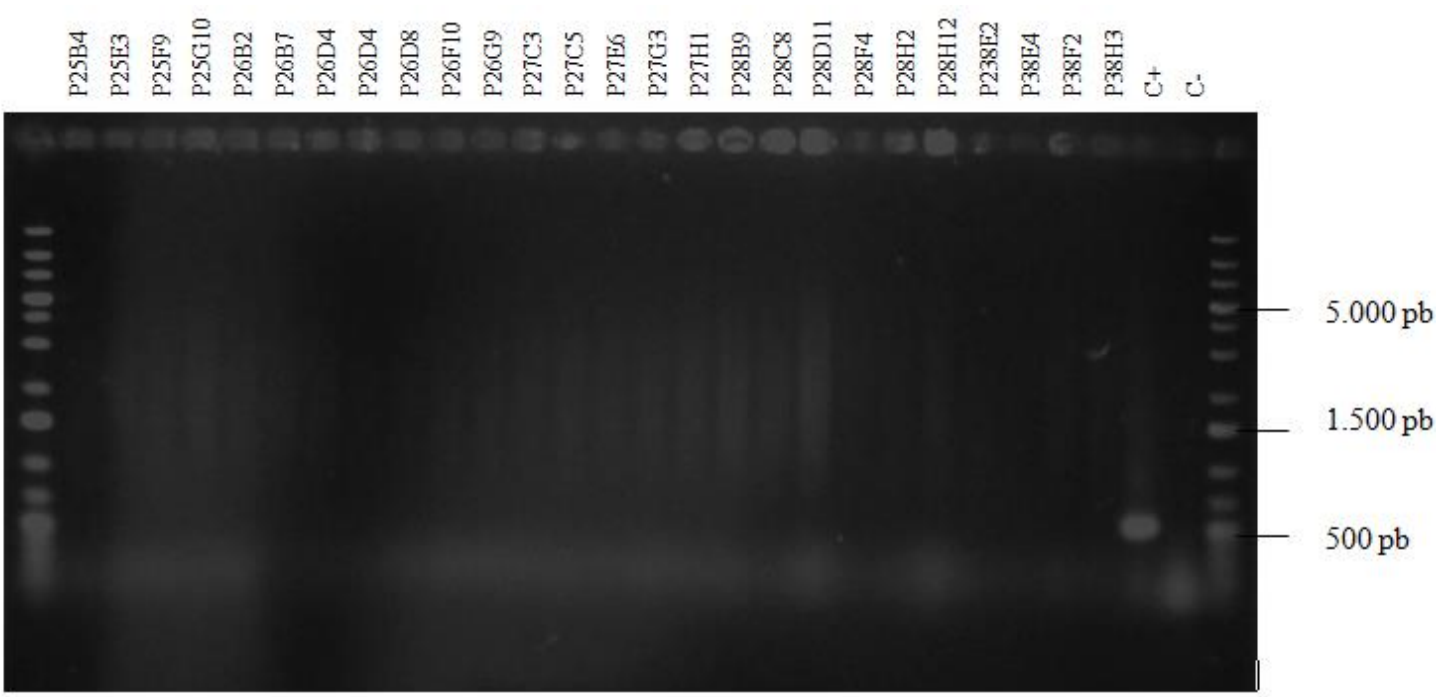

Figura 11-Perfil eletroforético em gel de agarose $0.8 \%(\mathrm{p} / \mathrm{v})$ resultante da amplificação por PCR dos clones descritos acima com o par de primer phaCF1/phaCR4.

O plano inicial para a confirmação dos clones positivos, consistia em selecionar 5 clones de cada classe, fazer as amplificações com os respectivos primers, fazer o sequenciamento e após a confirmação da presença de phaC realizar a clonagem desses genes em linhagens mutantes PHA negativas. Entretanto, esses clones inicialmente selecionados não apresentavam amplificação e por isso tentou-se de diversas formas repadronizar a reação de PCR, mudando parâmetros como temperatura de anelamento, quantidade de DNA, entre outros de acordo com dados previamente descritos na literatura (GALINDO, 2011; LÍCIO, 2011). Tendo em vista que a tentativa da padronização não estava sendo eficiente optou-se 
por outra estratégia, que consistiu em extrair os plasmídeos dos trezentos e noventa clones e fazer a amplificação com todos eles (figuras 12-27), fazendo um screening de toda a biblioteca supostamente positiva para diversas classes de PHA sintases, obtida anteriormente (GALINDO, 2011).

Classe I

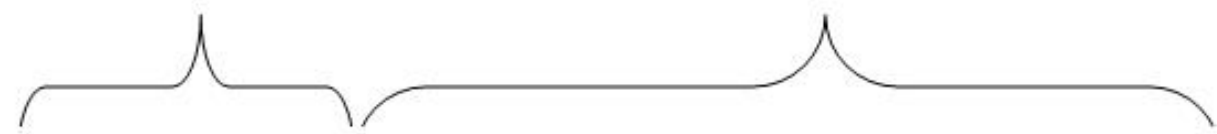

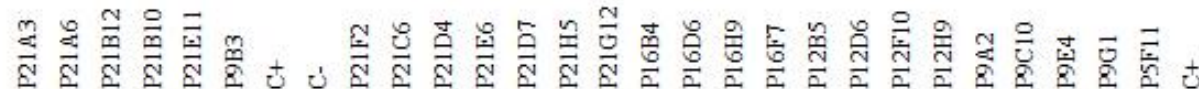

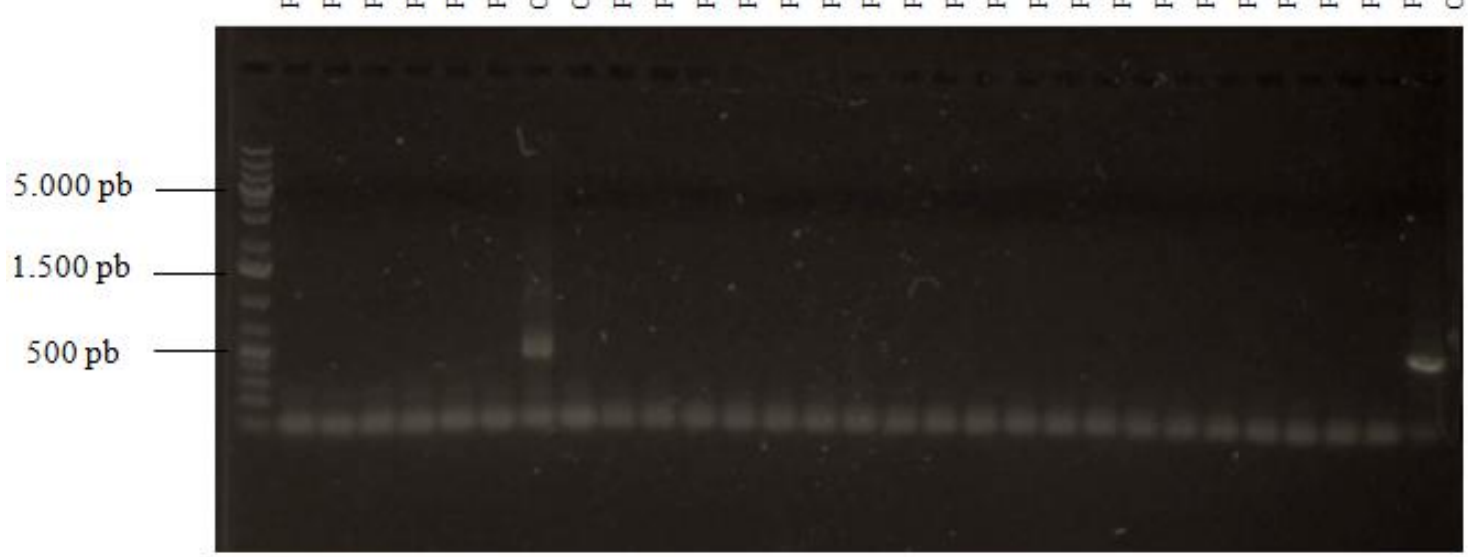

Figura 12-Perfil eletroforético em gel de agarose $0.8 \%$ (p/v) resultante da amplificação por PCR dos clones descritos acima com o par de primer phaCF1/phaCR4 para a classe I e 179L (a)/I-179R(a) para a classe II. 
Classe IV
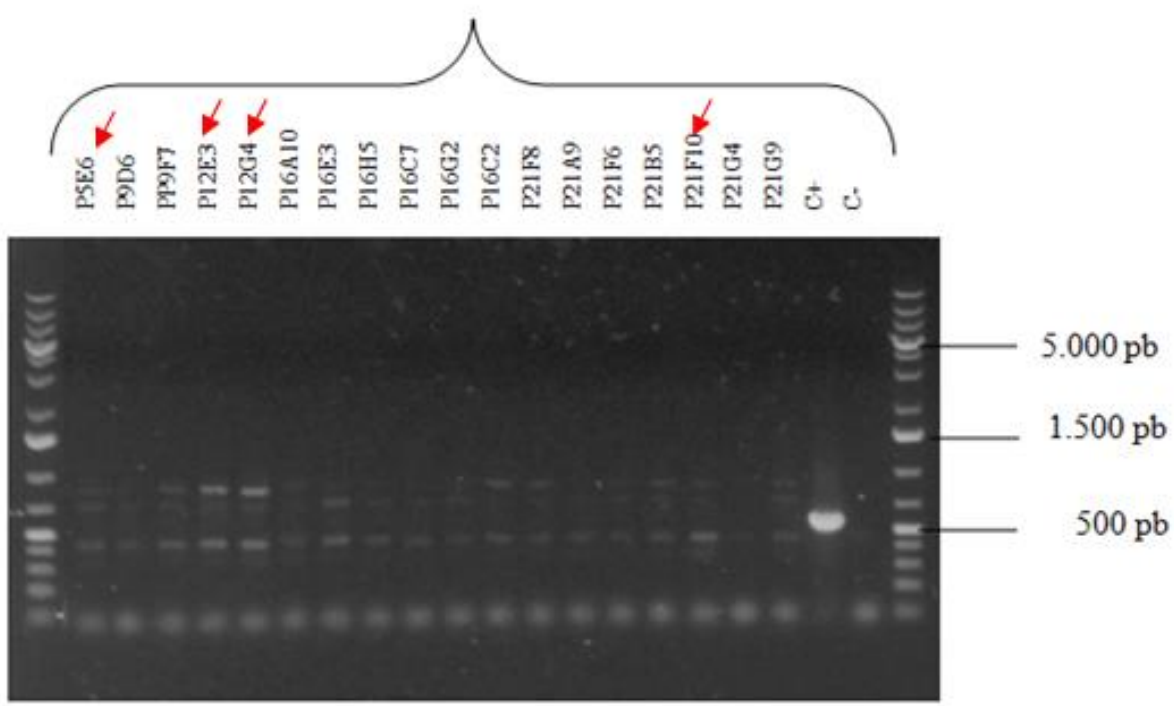

Figura 13-Perfil eletroforético em gel de agarose $0.8 \%$ (p/v) resultante da amplificação por PCR dos clones descritos acima com o par de primer BIF/BIR.As setas vermelhas indicam os amplicons que foram enviados para o sequenciamento.

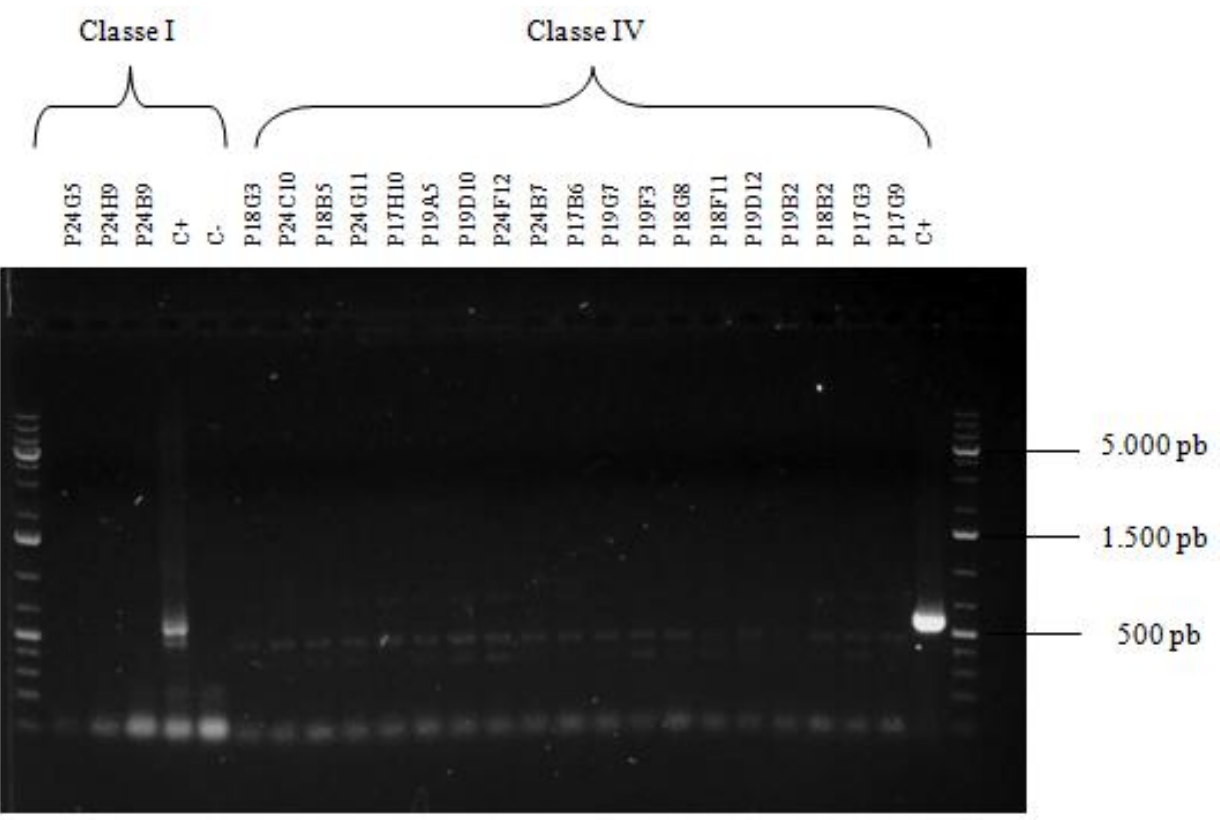

Figura 14-Perfil eletroforético em gel de agarose $0.8 \%$ (p/v) resultante da amplificação por PCR dos clones descritos acima com o par de phaCF1/phaCR4 para a classe I e BIF/BIR para a classe IV. 


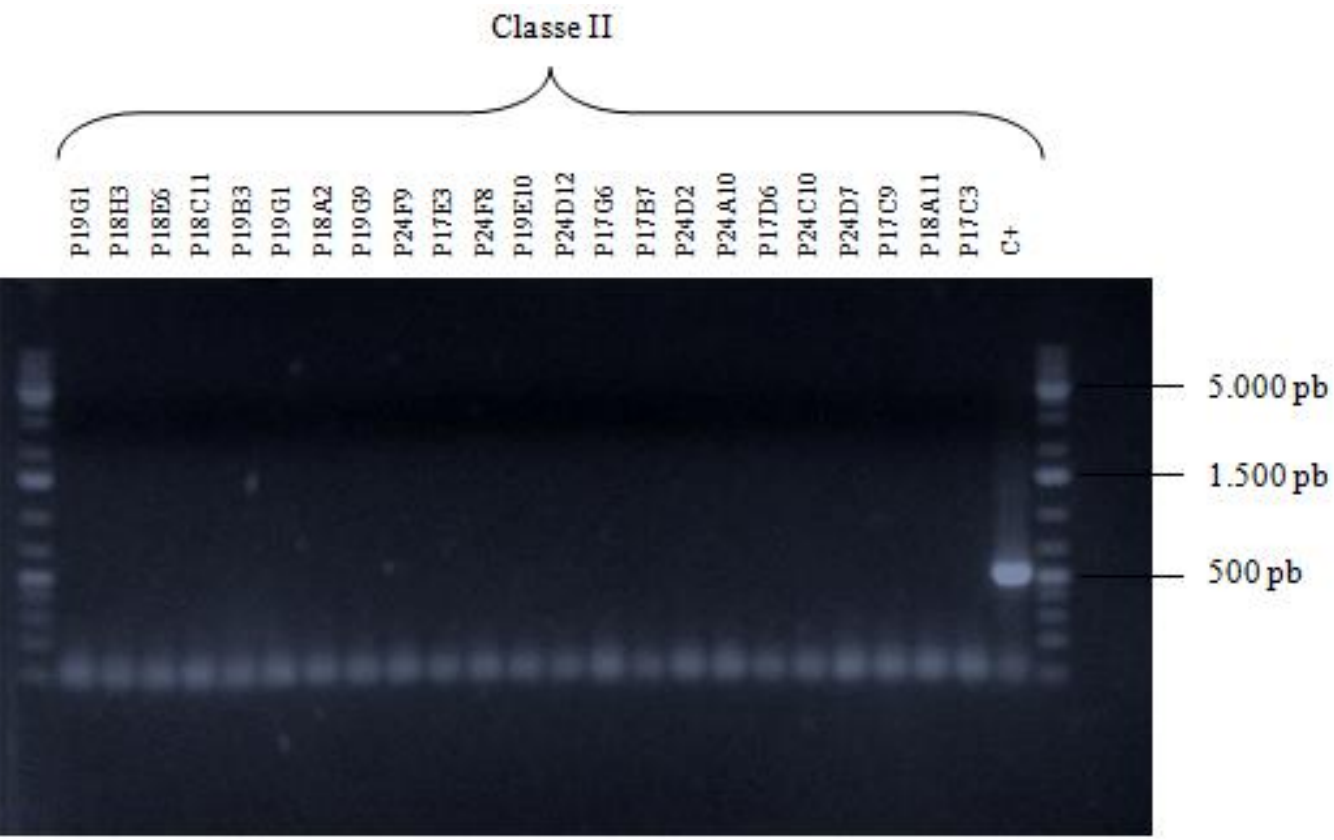

Figura 15- Perfil eletroforético em gel de agarose $0.8 \%(\mathrm{p} / \mathrm{v})$ resultante da amplificação por PCR dos clones descritos acima com o par de primer I-179L (a)/I-179R(a).

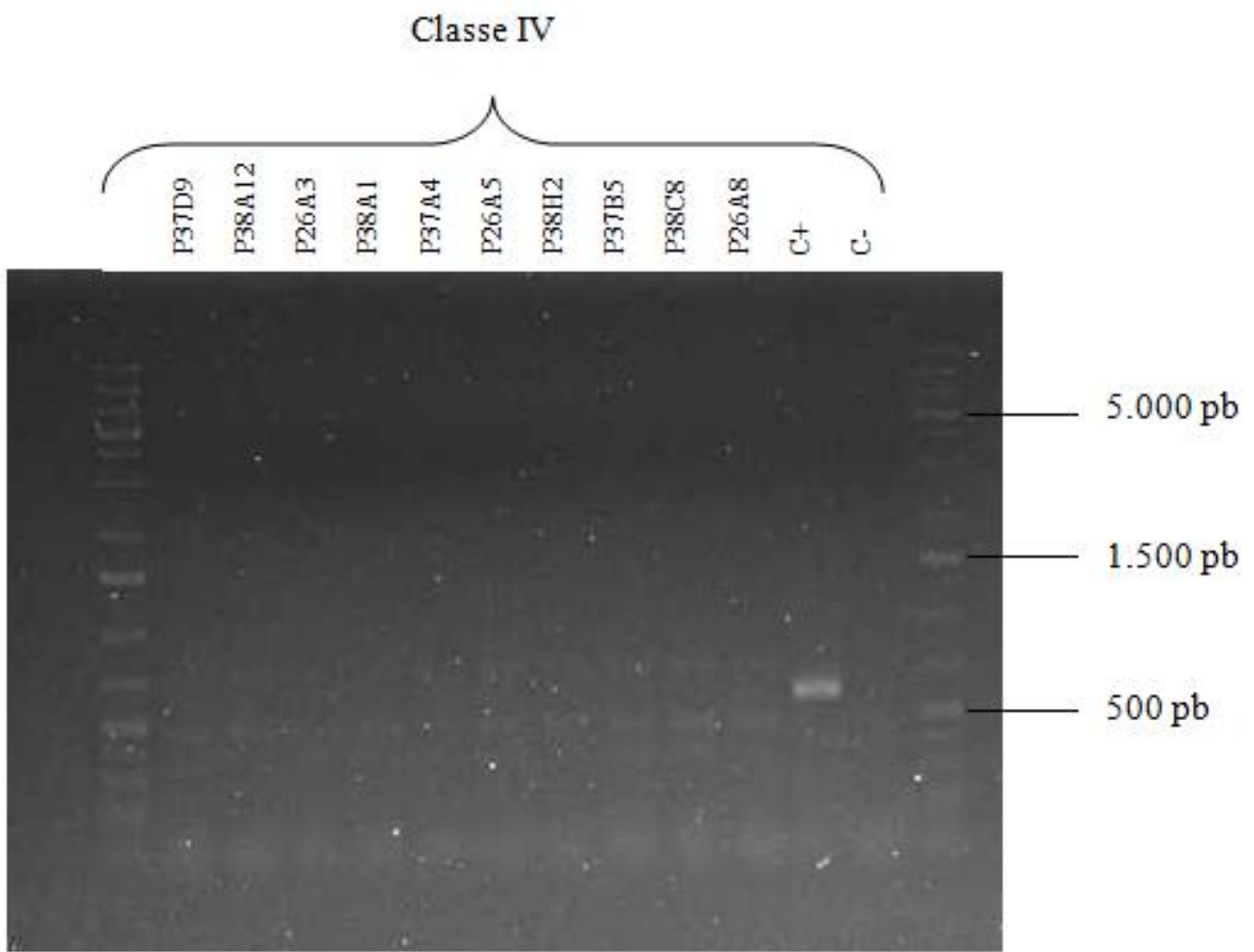

Figura 16- Perfil eletroforético em gel de agarose $0.8 \%(\mathrm{p} / \mathrm{v})$ resultante da amplificação por PCR dos clones descritos acima com o par de primer BIF/BIR. 


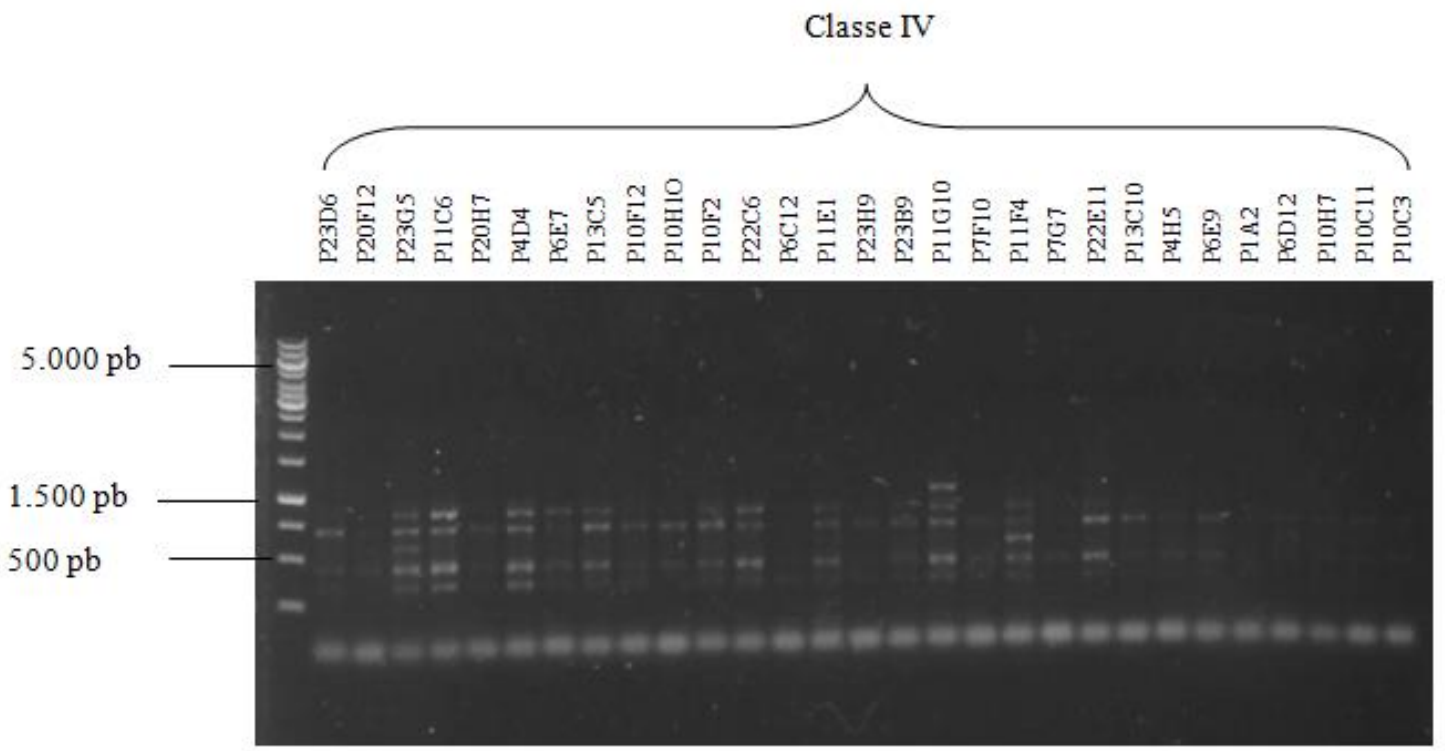

Figura 17-Perfil eletroforético em gel de agarose $0.8 \%(\mathrm{p} / \mathrm{v})$ resultante da amplificação por PCR dos clones descritos acima com o par de primer BIF/BIR.

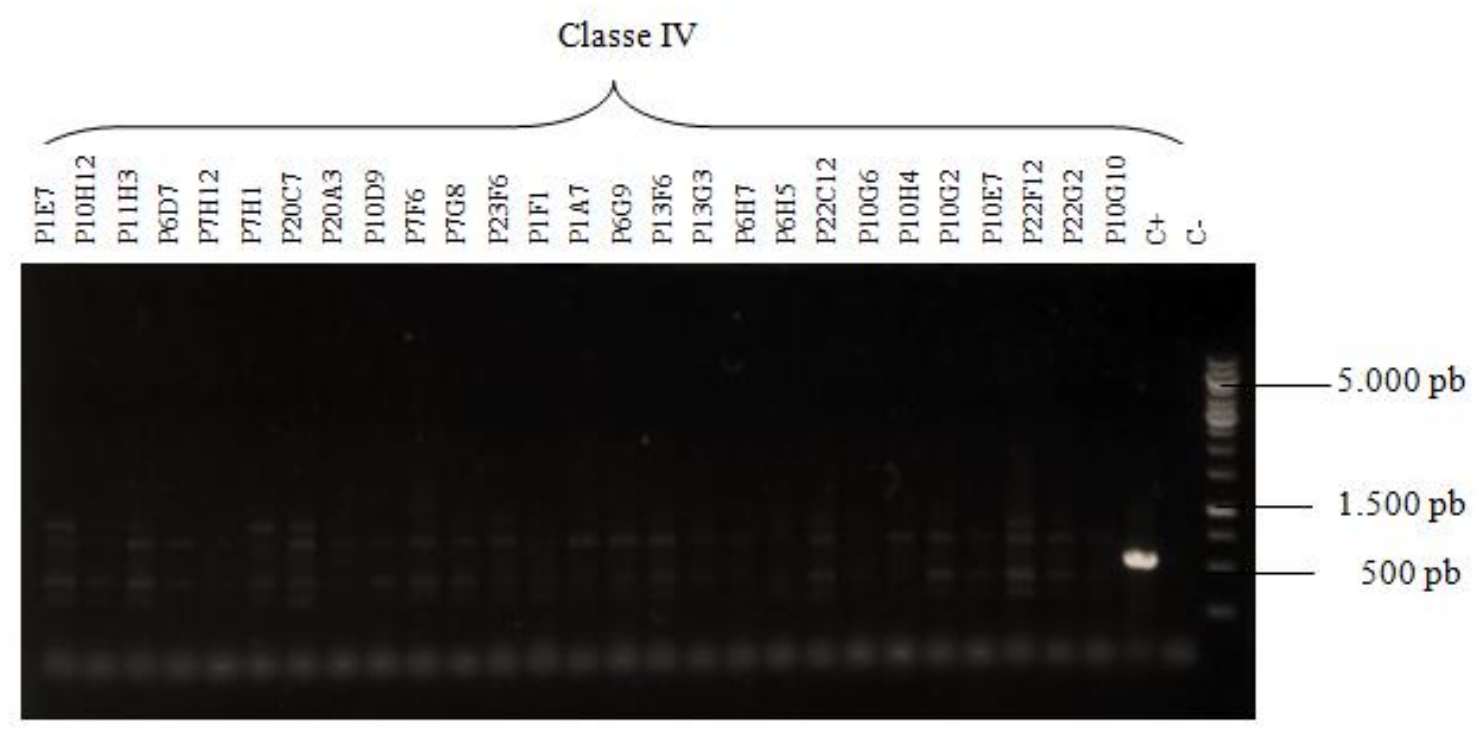

Figura 18-Perfil eletroforético em gel de agarose $0.8 \%$ (p/v) resultante da amplificação por PCR dos clones descritos acima com o par de primer BIF/BIR. 


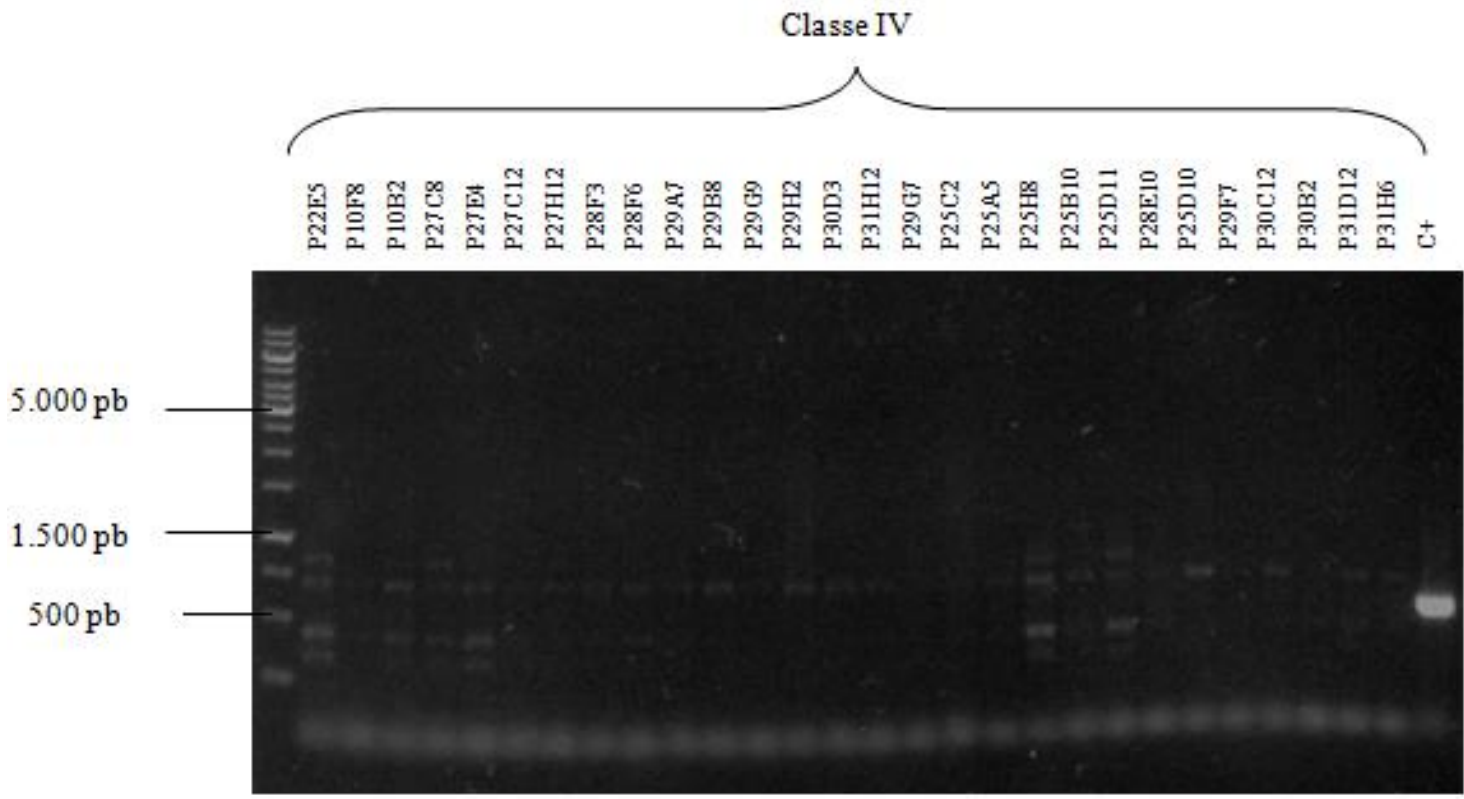

Figura 19-Perfil eletroforético em gel de agarose $0.8 \%(\mathrm{p} / \mathrm{v}$ ) resultante da amplificação por PCR dos clones descritos acima com o par de primer BIF/BIR.

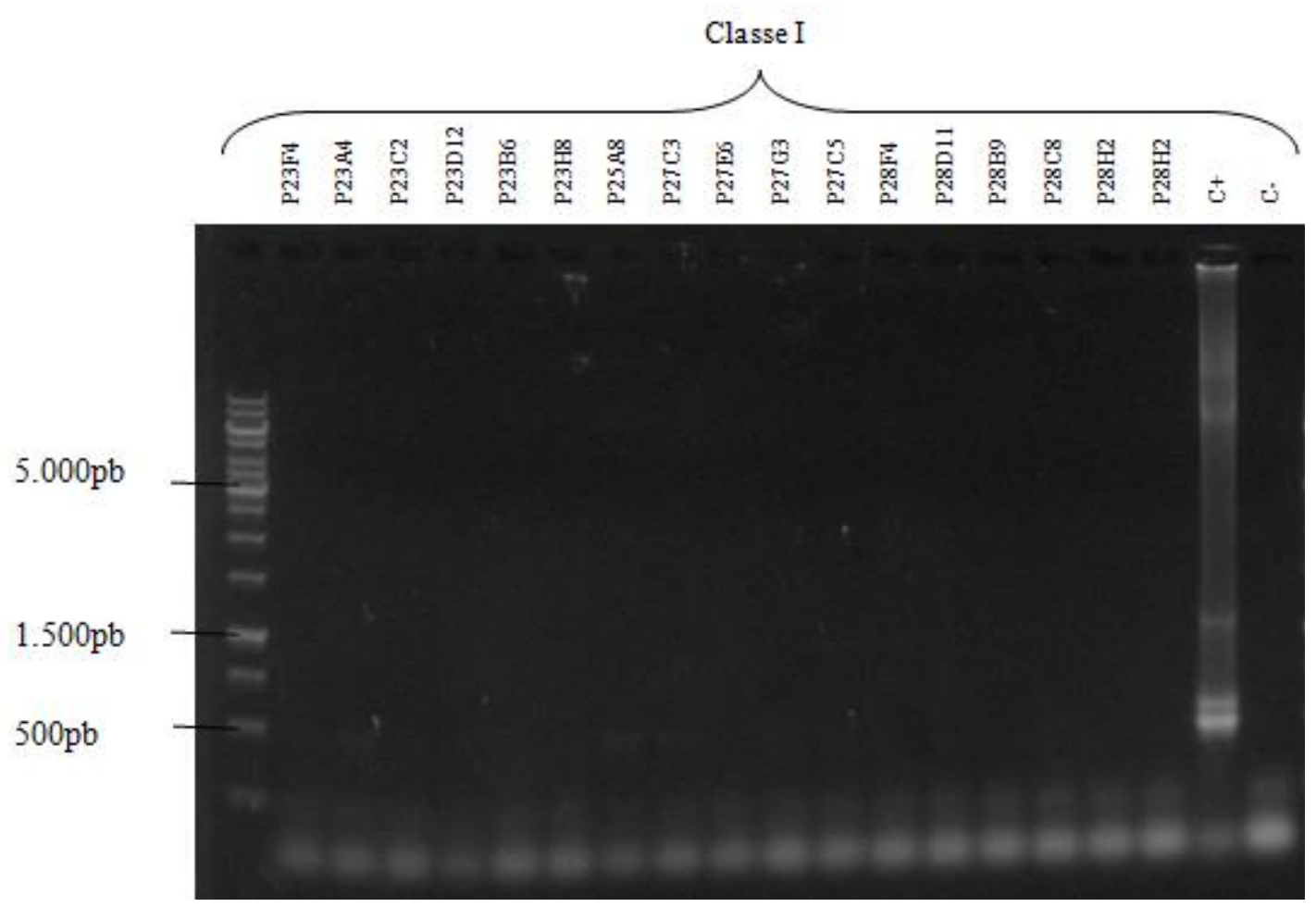

Figura 20- Perfil eletroforético em gel de agarose $0.8 \%$ (p/v) resultante da amplificação por PCR dos clones descritos acima com o par de primer phaCF1/phaCR4. 


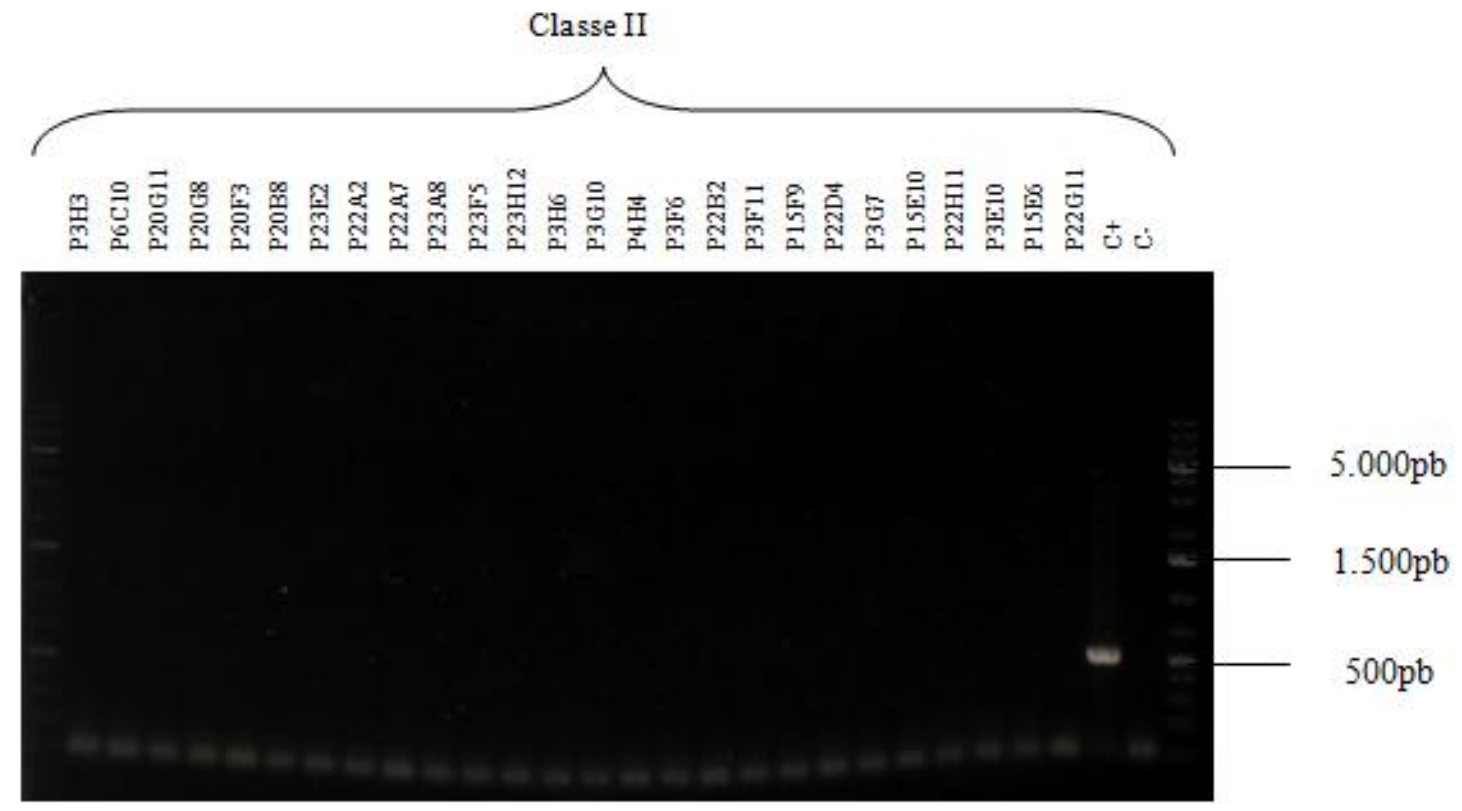

Figura 21-Perfil eletroforético em gel de agarose $0.8 \%(\mathrm{p} / \mathrm{v})$ resultante da amplificação por PCR dos clones descritos acima com o par de primer I-179L (a)/I-179R(a).

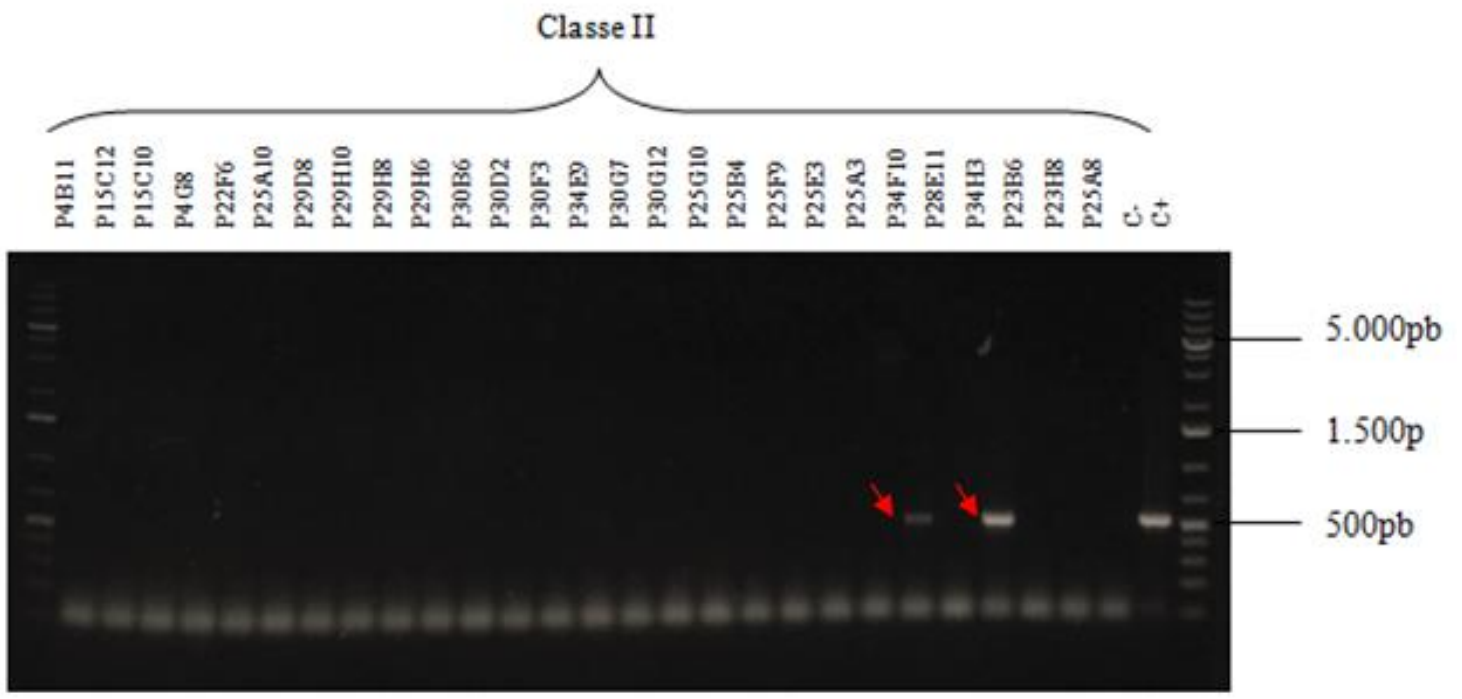

Figura 22-Perfil eletroforético em gel de agarose $0.8 \%(p / v)$ resultante da amplificação por PCR dos clones descritos acima com o par de primer I-179L (a)/I-179R(a). As setas vermelhas, indicam os amplicons que foram enviados para o sequenciamento. 


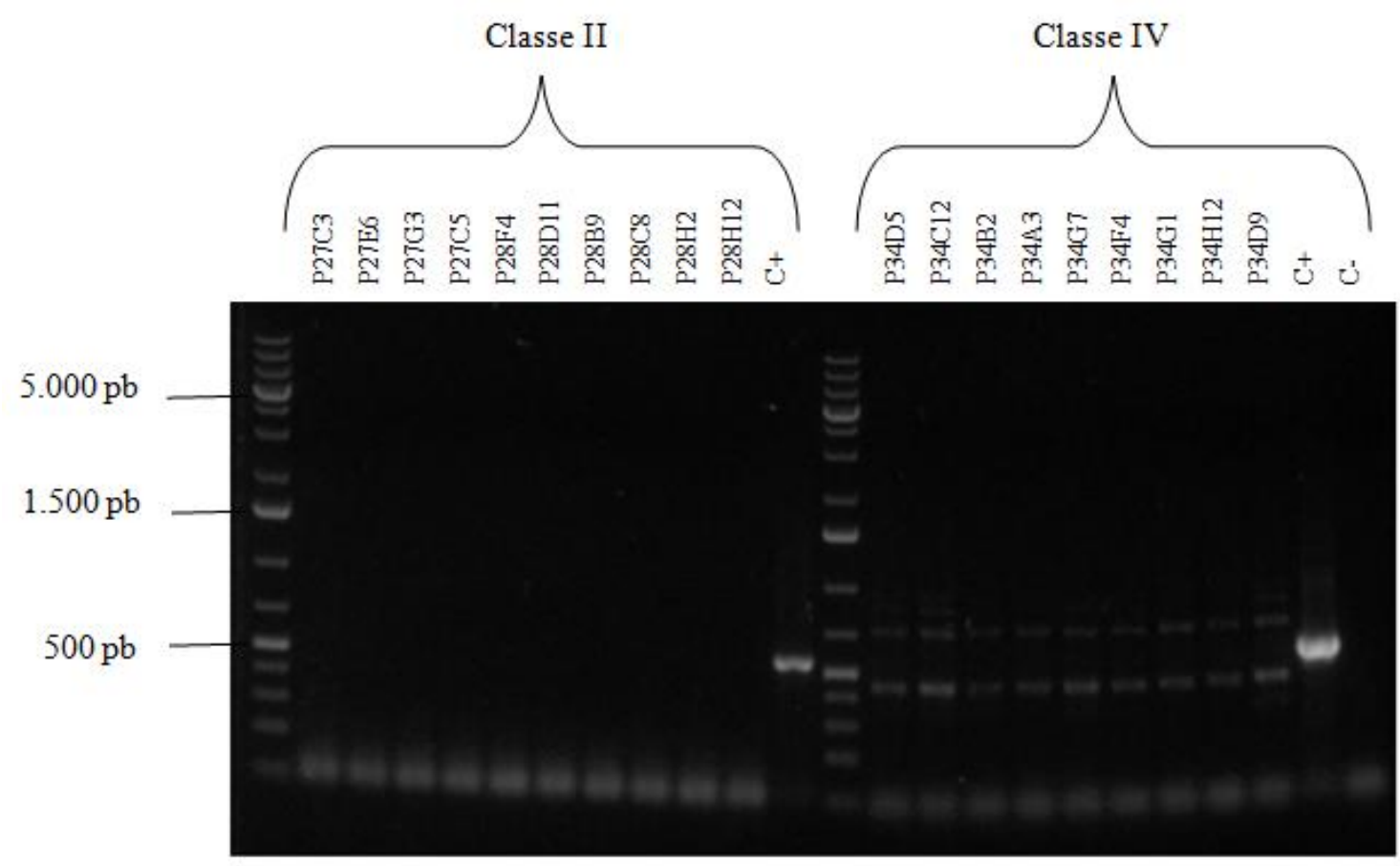

Figura 23-Perfil eletroforético em gel de agarose $0.8 \%(\mathrm{p} / \mathrm{v})$ resultante da amplificação por PCR dos clones descritos acima com o par de primer I-179L (a)/I-179R(a) para classe II e BIF/BIR para classe IV.

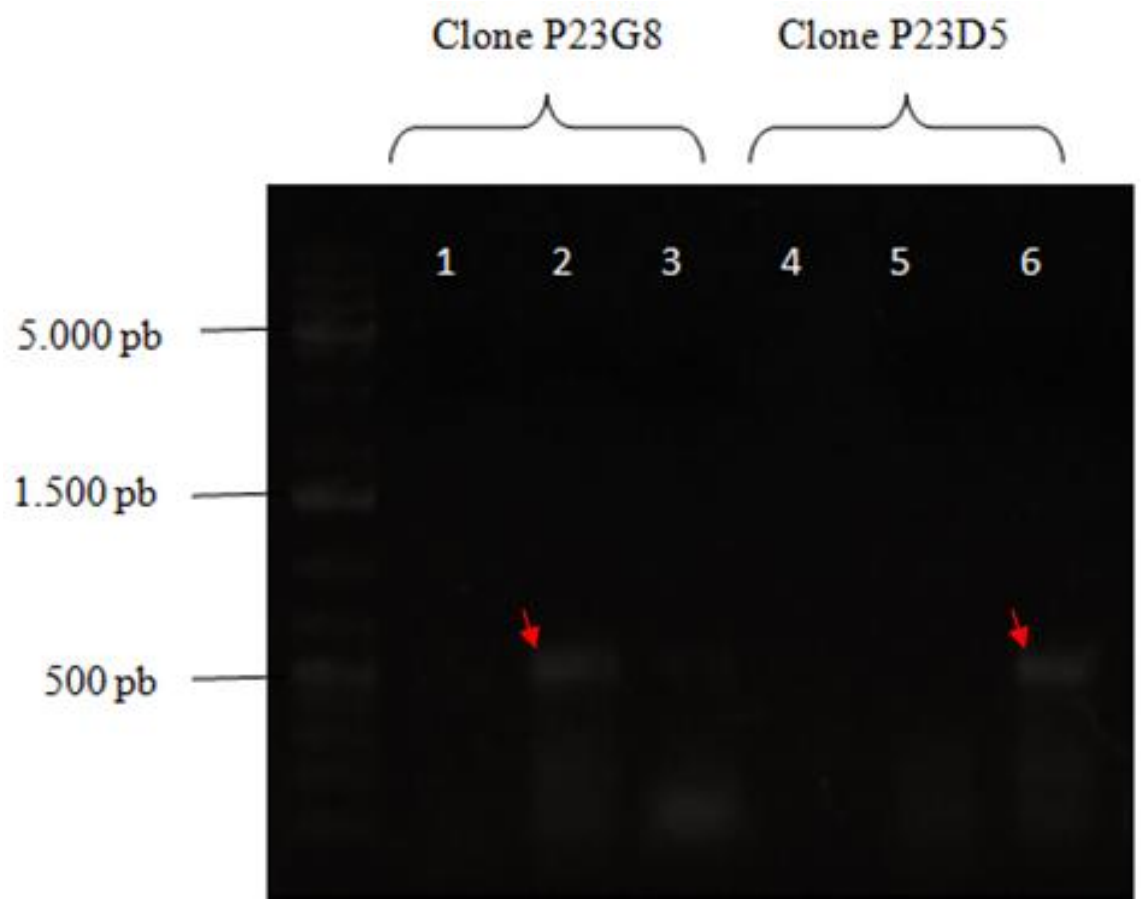

Figura 24-Perfil eletroforético em gel de agarose $0.8 \%(\mathrm{p} / \mathrm{v})$ resultante da amplificação por PCR dos clones descritos acima com o par de primer P1/P2 para as caneletas 1 e 4, phaC3F/phaC3F para as canaletas 2 e 6 e Haphapcr1/ Haphapcr2 para as canaletas 3 e 5. Todos esses primers são utilizados para a detecção de phaC de classe III. As setas vermelhas indicam os amplicons que foram enviados para sequenciamento 


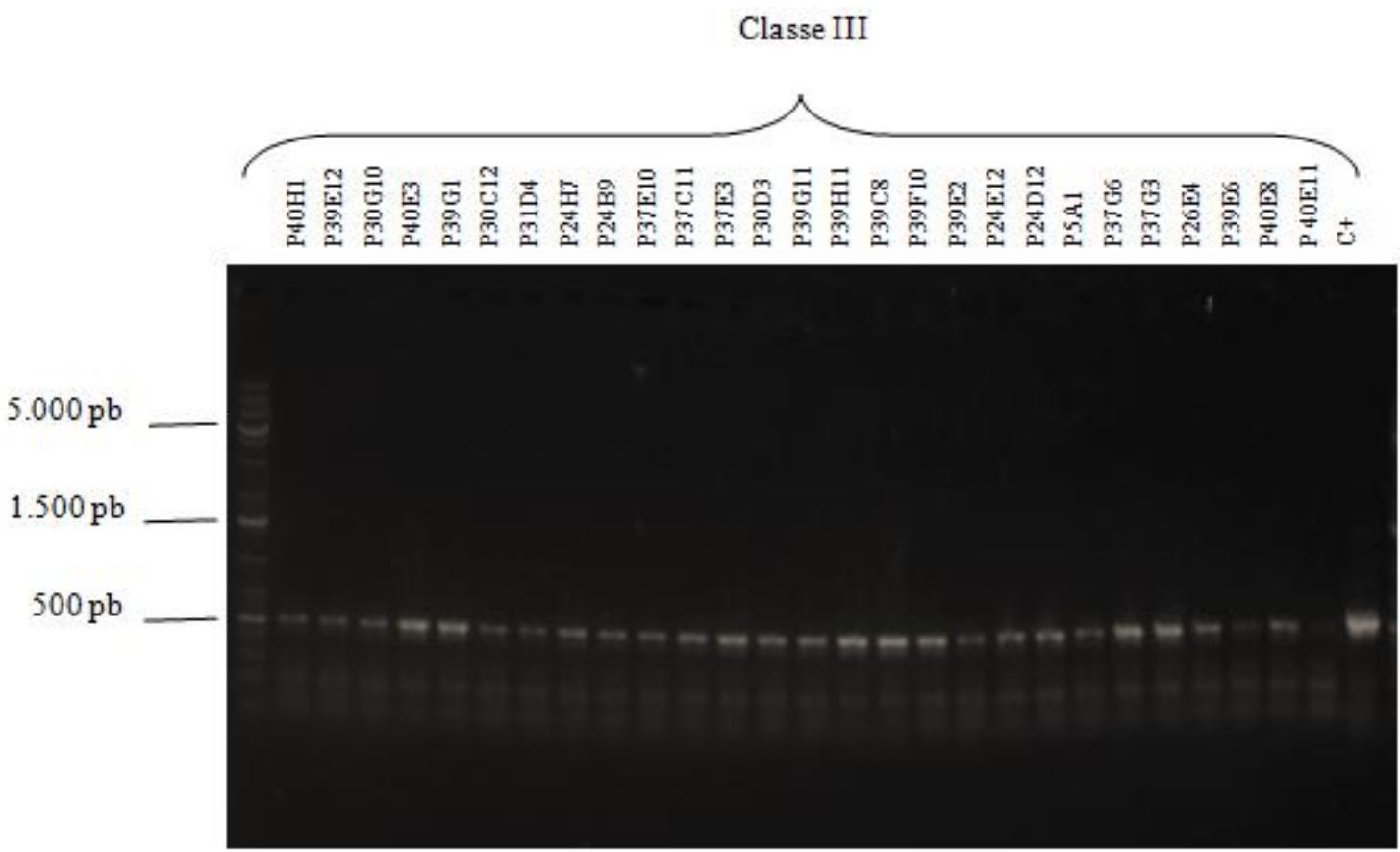

Figura 25- Perfil eletroforético em gel de agarose $0.8 \%(\mathrm{p} / \mathrm{v})$ resultante da amplificação por PCR dos $\begin{array}{lllllll}\text { clones descritos acima } & \text { com } & 0 & \text { par } & \text { de }\end{array}$ phaC3F/phaC3F

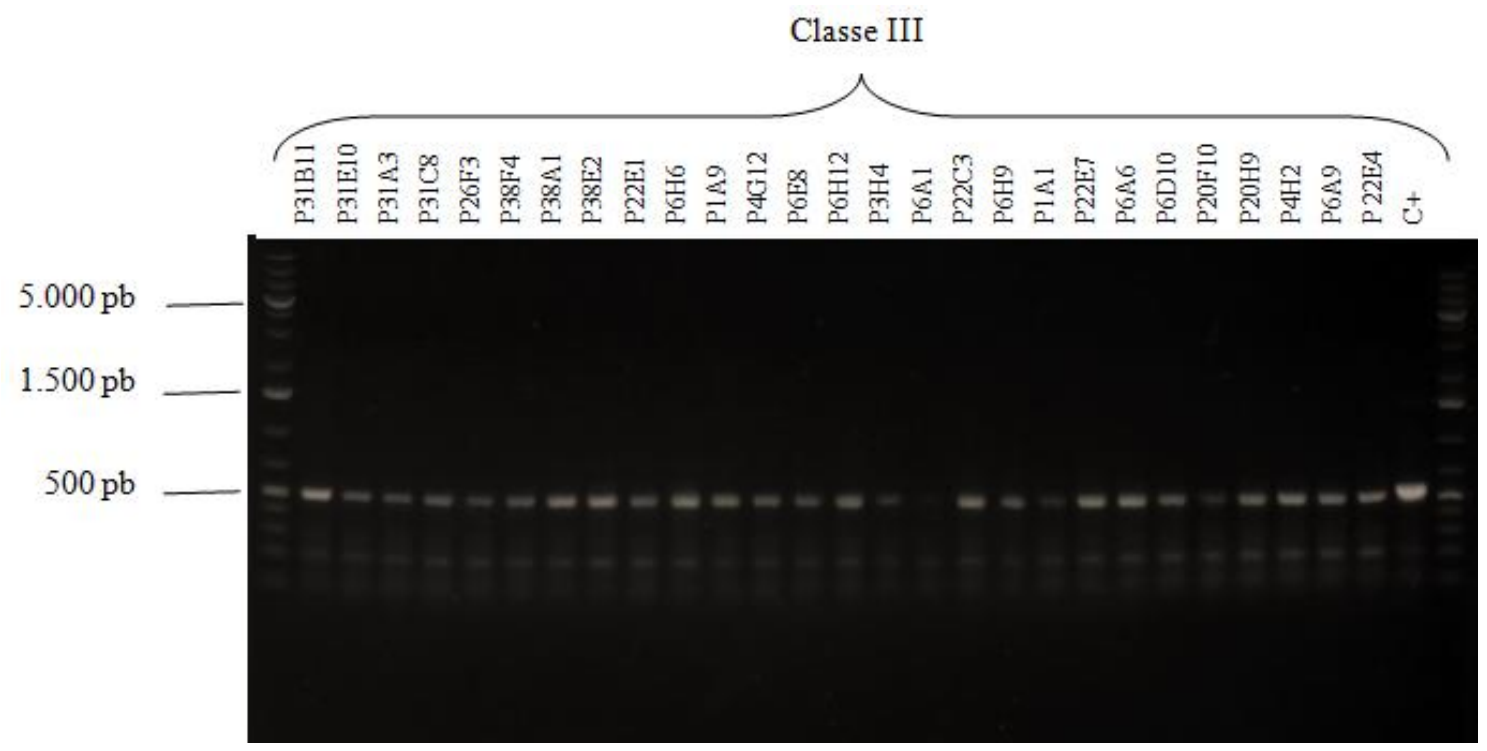

Figura 26-Perfil eletroforético em gel de agarose $0.8 \%$ (p/v) resultante da amplificação por PCR dos clones descritos acima com o par de primer phaC3F/phaC3F 


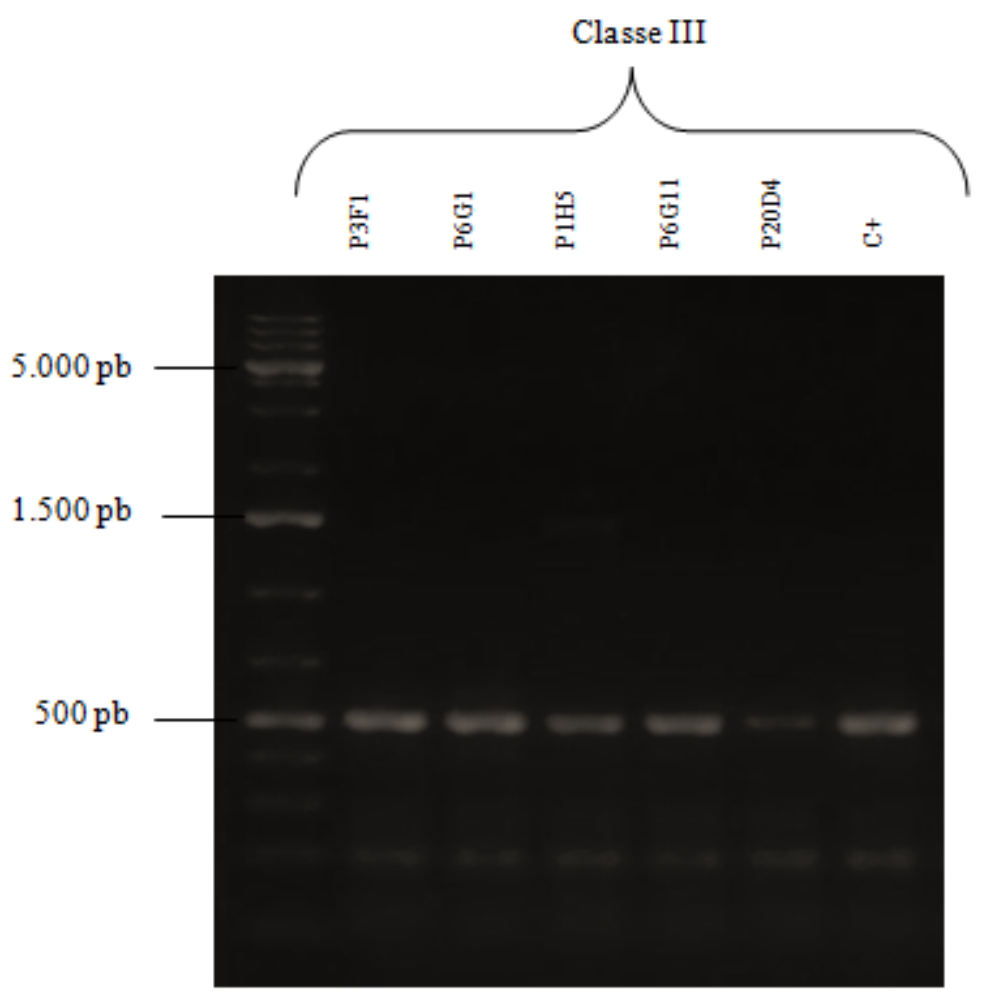

Figura 27-Perfil eletroforético em gel de agarose $0.8 \%(\mathrm{p} / \mathrm{v})$ resultante da amplificação por PCR dos clones descritos acima com o par de primer phaC3F/phaC3F.

Em trabalho anterior (GALINDO, 2011) demonstrou-se que dos 390 clones positivos, 50 possuíam phaC da classe I, 120 da classe II, 67 da classe III e 153 da classe 4. No presente trabalho, 2 clones de classe II e 65 de classe III se confirmaram positivos. Os positivos de classe II e mais dois amplicon da classe III, foram enviados para sequenciamento, para confirmar se eram PHA sintase. O sequenciamento de dois amplicons que se mostraram positivos para classe III, indicou que se trata de falso positivos decorrentes provavelmente da falta de especificidade dos primers, o que leva à amplificação de sequências que não codifiquem uma PHA sintase. Isso acontece porque os primers utilizados de classe III apresentam um grande número de degenerações, o que os tornam relativamente inespecíficos. Entretanto essas degenerações são necessárias, pois não há um grande número de genes de PHA sintase de classe III sequenciados, o que limita a forma de desenhar os primers. Além disso, esses primers não foram anteriormente empregados na literatura para triagens, o que restringe sua aplicação (GALINDO, 2011; HAI et al., 2001). 
Além dos artefatos metodológicos envolvidos na detecção de PHA sintase de classe III, pela limitação dos iniciadores, deve-se atentar para o fato de que os microrganismos portadores de tal gene são encontrados em ambientes aquáticos, como lagoas, águas salobras, restingas, estuários e habitats marinhos diversos. São, em geral, bactérias do enxofre, como espécies de Allochromatium, proteobacterias capazes de realizar fotossíntese, encontradas em zonas iluminadas anóxicas em lagos ou outros habitats onde se acumula o sulfeto de hidrogênio, não utilizando água como agente redutor, portanto, sem produzir oxigênio. Utilizam o $\mathrm{H}_{2} \mathrm{~S}$, que é oxidado, gerando grânulos de enxofre elementar acumulados intracelularmente. Uma vez que a biblioteca foi feita a partir de solo de mata atlântica, a presença desses organismos nesse tipo de ambiente deve ser rara (GALINDO, 2011).

No screening inicial, feito com amostras de lisados dos clones, observaram-se 16 clones positivos. Dessa forma, a hipótese que gerou a necessidade de confirmar os resultados anteriores, leva à indicação de que os resultados iniciais eram falso- positivos.

Apesar de 139 clones de classe IV apresentarem inúmeros amplicons após a reação de PCR, nenhuma delas era do tamanho exato do controle positivo. A princípio acreditou-se que poderia se tratar de um novo gene PHA sintase, ou que o gene encontrado poderia conter algumas modificações. Entretanto, amplicons de 5 clones foram selecionados e sequenciados e os resultados indicaram que realmente se tratava de falso-positivos. A maioria dos amplicons apresentava similaridade com o gene anotado como codificador de uma holo-[acylcarrier-protein] sintase, resultado já obtido anteriormente com o mesmo par de primers (GALINDO, 2011). A ausência de positivos de gene de PHA sintase classe IV em biblioteca metagenômica de solo foi obervada anteriormente (DIMITROV, 2009), onde uma biblioteca inicial de um total 10.570 clones não apresentou nenhum amplicon positivo para o gene PHA sintase de classe IV, utilizando sondas com a sequência do primer B1F/B1R. Nesse trabalho, autor atribui a falta de amplificação à falta de sequências complementares ao primer.

Ao que parece, a detecção desse tipo de PHA sintase no solo é um problema metodológico, pois o solo é extramente rico em Bacillus, gênero em que é predominantemente encontrada $p h a C$ de classe IV. Além disso, problemas com esse primer já foi anteriormente relatado (SHAMALA et al., 2003) e acredita-se que uma forte limitação desse par de oligonucleotídeo seja o fato de que ele foi desenhado a partir de uma única sequência de PHA sintase B.megaterium. Um alinhamento de sequências de phaC de diversas espécies de Bacillus com a sequência do primer, feito no programa clustalW (figura 30 e 31), demonstrou que a região utilizada no alinhamento para delinear o não é uma região conservada. Para 
confirmar a eficiência do primer, realizou-se um PCR "in silico" com a sequência de PHA sintase de diversas espécies de Bacillus, mas só foram obtidos resultados positivos para Bacillus megaterium.Outras espécies de Bacillus como Bacillus pseudofirmus OF4, Bacillus cytotoxicus NVH 391-98 e Bacillus cereus E33L não apresentaram amplificação, pela falta de pareamento de sua sequência com a sequência do primer.

Vale ressaltar, que no trabalho anteriormente citado (DIMITROV, 2009) dos 10.570 clones que foram triados a partir dos macroarranjos, 8 foram positivos quando utilizou-se a sonda obtida com o primer phaCF1/phaCR4, 6 foram positivos quando utilizou-se q sonda obtida com o primer I-179L(a)/I-179R(a), 1 foi positivo quando utilizou-se a sonda obtida com o primer Haphapcr1/Haphapcr2. Entretanto, dos 14 clones detectados positivos, apenas 5 foram confirmados por PCR e os outros foram concebidos pelo autor como falso positivos, que podem ter aparecido pelo pareamento inespecífico durante a confecção das sondas, em que o DNA metagenômico do solo foi amplificado por PCR, com uso de primers degenerados (DIMITROV, 2009).

No presente trabalho, a biblioteca inicial continha aproximadamente 5.000 clones, dos quais 390 foram detectados como positivos a partir de reações de PCR. Após a confirmação desses resultados, apenas 2 foram detectados como positivos. Apesar de ser um resultado com grande discrepância do inicial, não é um número atípico para uma biblioteca metagenômica. Um trabalho que buscava por celulases e enterases em uma biblioteca de 100 mil clones, obteve-se apenas 4 clones positivos (REES et al., 2003).

Outro caso similiar foi observado na literatura, em um trabalho recentemente publicado, em que uma biblioteca metagenômica de solo contaminado por óleo (CHEEMA et al., 2012) foi construída, obtendo-se $2.1 \times 10^{6}$ clones, que foram triados com o primer phaCF1/phaCR4, dos quais foram obtidos 9 positivos para genes de PHA sintase.

Embora as técnicas de triagem de bibliotecas metagenômica apresentem algumas limitações, há algumas alternativas que se mostram cada vez mais eficientes. Em trabalho recente (ANEJA et al., 2004; SCHALLMEY et al., 2011), um grupo de pesquisadores conseguiu isolar genes de PHA sintase com sequências similares, mas substancialmente diferentes das PHA sintases conhecidas através da triagem fenotípica obtida por complementação. Nesse caso, a biblioteca foi construída em cosmídeos, que foram inseridos em Sinorhizobium meliloti, mutantes, PHA negativos. Dessa forma, os cosmídeos contendo os insertos grandes o suficiente para abrigar o gene inteiro foram capazes de complementar e restaurar a produção de PHA dessa linhagem. 
Em trabalho feito em 2011 em nosso laboratório (GALINDO, 2011), foi realizado um teste para verificar se a triagem poderia ser feita por avaliação fenotípica, utilizando E. coli como hospedeira e a detecção de clones produtores de PHA, utilizando a coloração de Sudan Black B, após cultivo em meio sólido sob condições propícias ao acúmulo. Entretanto, o vetor utilizado nessa biblioteca não é um vetor de expressão, o que exige que o inserto contenha além do gene, o seu promotor. Nesse experimento não foi obtido nenhum clone capaz de produzir PHA após o recebimento do inserto, o que sugere que os vetores não possuíam a sequência dos genes e seus promotores.

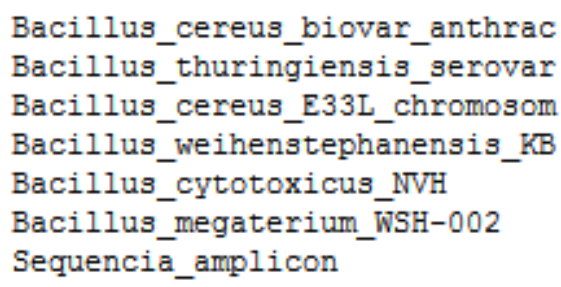

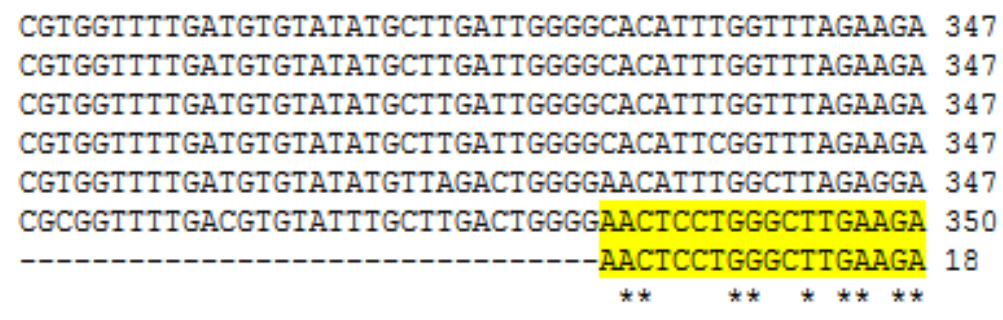

TAGTCATTTGAAATTTGATGATTTCGTGTTTGATTATATTGCAAAAGCAG 397 TAGTCATTTGAAATTTGATGATTTCGTGTTTGATTATATTGCAAAAGCAG 397 TAGTCATTTGAAATTTGATGATTTCGTGTTTGATTATATTGCAAAAGCAG 397 TAGTCATTTGAAGTTTGATGATTTCGTGTTCGATTATATTGCAAAAGCAG 397 TCGTCATTTGAAATTTGATGATTTCGTATTCGACTATATTGCAAAAGCAG 397 CAGCAATATGAAGCTAGATGATTATATTGTAGATTATATTCCAAAAGCGG 400 CAGCAATATGAAGCTAGATGATTATATTGTAGATTATATTCCAAAAGCGG 68

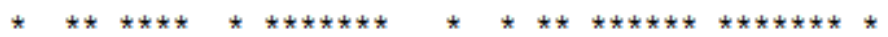

Figura 30 Alinhamento da sequência do primer B1F (destacada em amarelo) com as sequências de phaC de diversar espécies de Bacillus

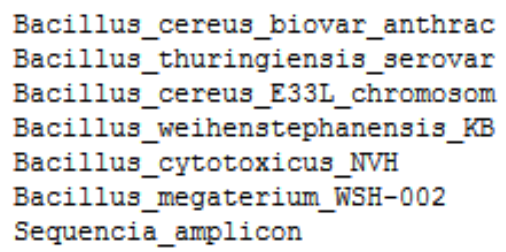

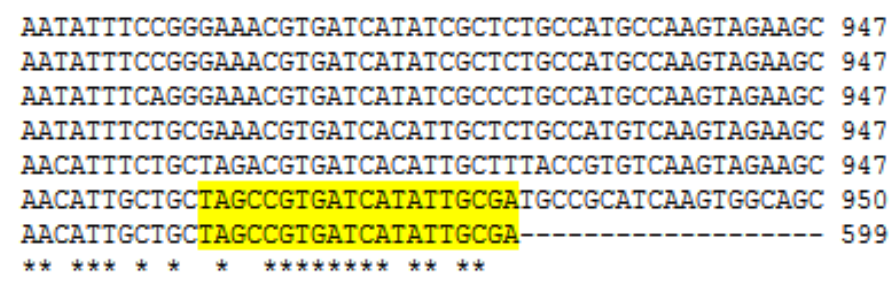

Figura 31 Alinhamento da sequência do primer B1F (destacada em amarelo) com as sequências de phaC de diversar espécies de Bacillus

\subsection{Sequenciamento de fragmentos de DNA dos clones positivos}

Após a obtenção dos clones positivos, as amostras de DNA foram enviadas para o sequenciamento e foram analisadas para a obtenção da sequência consenso. Segue abaixo a 
sequência do DNA obtido do clone P12F10. As sequências restantes de classe IV encontramse no apêndice.

A amplificação a partir do clone P12F10 (figura 14), apresentou 4 bandas que foram enviadas para o sequênciamento:

Banda de 750 pb - 96\% de similaridade com hypothetical protein de E.coli TTTTTTTTGWTGYCTCTCSGCTGGTTTTACTTACCCACCGCGCGCGATACCGGGTGCCAGGAGAACT GGTTTGCTGGAAACAGCCACGGGCCGCGATTTCTGAGGCTTCTTTACCGCTAATTTCTTGSCGSATC CATTCCCGCGCAGCTTCTGGCGACAGTACCAGTGGGCGGCGGTCATGAATATCTACCAGACCTTGA TCTGCCGCAGCAGTGACGATCAAAAATCCTTCGGCTTCGTCACCACGCTCAAATGGTGTGCTACCT ATCGCGGCCATAAAAATAGGTTGTCCATCAGCACGATAGATAAAAAAAGGCTGTTTTTTGTCGCCT TCTTTTTTCCACTCAAACCAGCCATCGGCAAAACAGATTGCCCGACCATGTTGCCAGAGCGGTTTA AACATACGACTGGTTGCCGCAGTTTCTACGCGGKCKTTTWTCAGCGGCGGTTTATCCCACCWTCCG GGAGCATATCCCCAGAAAACCGGATCCAGATGAAGGTGTTCATCACGTTCACTGAGCAGWAGGAC TTTGGTTCCCCGGCGCGACGTTGTATCTGCCAATGGGTTCGGGATCATAGGGAAATATCGCGTTCA ATATCTTCCGCGAGAAGCGCARGGTAAWYCTTCACGCGTTGGGGATTGGGSCAAAGCGTCCACMC ATAGAAACCTCCTGAKATCATACTGAAAAGAATAGGAGTGGGGGGCGGGWAAAATCTATGGGAY

Banda de 700 pb - 99\% de similaridade com Holo-[acyl-carrier-protein] synthase de $E$. coli

TTGAGGGTGCATGCTGCACAAAATTAAAGTTAAAAAGTAAAACCCCCGTTCCTTACCAGTTCGGGG GTTTTACTTTTTAAAGAGAACGGTATTATTTTTAACTTTCAATAATTACCGTGGCACAAGCATAGTG CCGCTCATCTGCCAGCGTTACATG-TATTTGCAACGCCCAGCTTTTCCGCCA

Banda de 450 pb - 99\% de similaridade com Holo-[acyl-carrier-protein] synthase de $\boldsymbol{E}$. coli

GATCTGTGGCATGGTGTAAGCACAGCAAATCTTCAATAACGAAGCCAATTTTAATGTACTTCGAAT TGGCGGTCACGTTAATCTTTCCATCAATATTGCTTTCTTCGTAAAGGCTCGAGTTTTTATGCTAAAG ATTGCAAGTTGCTTGTAAAAGATAAGTACACTGATCCATAATCGCTGTTGTTGAGGGTGCATGCTG CACAAAATTAAAGTTAAAAAGTAAAACCCCCGTTCCTTACCAGTTCGGGGGTTTTACTTTTTAAAG AGAACGGTATTATTTTTAACTTTCAATAATTACCGTGGCACAAGCATAGTGCCGCTCATCTGCCAGC GTTACATGCATATTTGCAACGCCCAGCTTTTCCGCCAGTTTTAATGCCTCGCCCCATAGCCGTAGCC GTGATCATTATTGCG

Banda de 400pb - 99\% de similaridade com Holo -[acyl-carrier-protein] synthase de $E$. coli

GGATCTGTGGCATGGTGTAAGCACAGCAAAATCTTCAATAACGAAGCCAATTTTAATGTACTTACG AATTGGCGGTCACGTTAATCTTTCCATCAATATTGCTTTCTTCGTAAAGGCTCGAGTTTTTATGCTA AAGATTGCAAGTTGCTTGTAAAAGATAAGTACACTGATCCATAATCGCTGTTGTTGAGGGTGCATG CTGCACAAAATTAAAGTTAAAAAGTAAAACCCCCGTTCCTTACCAGTTCGGGGGTTTTACTTTTTAA AGAGAACGGTATTATTTTTAACTTTCAATAATTACCGTGGCACAAGCATAGTGCCGCTCATCTGCCA 
GCGTTACATGCATATTTGCAACGCCCAGCTTTTCCGCCAGTTTTAATGCCTCGCCCCATAGCCGTAG CCGTGATCATATTG

Os controles positivos das classes I, II e IV foram enviados para o sequenciamento para confirmar que se tratava da sequência de genes da PHA sintase e suas sequências apresentaram 99\%, 99\% e 96\% de similaridade com o gene de PHA sintase de Ralstonia eutropha, Pseudomonas aeruginosa e Bacillus megaterium respectivamente.

Os DNAs obtidos a partir dos clones positivos de classe III, P23G8 e P23D5 (figura 26), também foram enviados para o sequenciamento e ambos apresentaram similaridade com o gene Glutamina sintetase de E. coli. Esse resultado também foi obtido no trabalho de Galindo, que justificou esse resultado, pelo alto número de degenerações no primers, o que faz com que ele seja complementar a sequências inespecíficas (GALINDO, 2011).

P23G8 - 99\% de similaridade com glutamina sintetase de E.coli CCGACCACCAACTCTTATAAGCGTCTGGTCCCGGGCTATGAAGCAGCTCTAATGCTGGCTTACTGT GCGCGTAACCGTTCTGCGTCTATCCGTATTCCGGTGGTTTCTTCTCCGAAAGCACGTCGTATCGAAG TACGTTTCCCGGATCCGGCAGCTAACCCGTATCTGTGCTTTGCTGCCCTGCTGATGGCCGGTCTTGA TGGTATCAAGAACAAGATCCATCCGGGCGAAGCCATGGACAAAAACCTGTATGACCTGCCGCCAG AAGAAGCGAAAGAGATCCCACAGGTTGCAGGCTCTCTGGAAGAAGCACTGAACGAACTGGATCTG GACCGCGAGTTCCTGAAAGCCGGTGGCGTGTTCACTGACGAAGCAATTGATGCGTACATCGCTCTG CGTCGCGAAGAAGATGACCGCGTGCGTATGACTCCGCATCCGGTAGAGTTTGAGCTGTACTACAGC GTCTAAGTGTTTTAGTTGCCGTGGA

\section{P23D5 - 95\% de similaridade com glutamina sintetase}

ACGCTGTAGTACAGCTCAAACTTTACCGGATGCGGAGTCATACGCACGCGGTCATCTTCTTCGCGA CGCAGAGCGATGTACGCATCAATTGCTTCGTCAGTGAACACGCCACCGGCTTTGAGGAACGCGGTC CACAGATCCAGTTCGTTCAGTGCTTCTTCGAGAGAGCCTGCAACCTGTGGGATCTCTTTCGCTTCTT CTGGCGGCAGGTCATACAGGTTTTTGTCCATGGCTGCCCGCATGGATCTTGTTCTTGATATAATAAA GACCGGCCATCAGCAGGGCAGCGAAGCACAGGTACAGGTTTGCGCTGGGATCCGGGAAACGTACT TCGATACGACGTGCTTTCGGAGAAGAAACCACCGGAATACGGATAGACGCAGAACGGTTACGCGC AGAGTAAGCCAGC

Os dois clones positivos de classe II, P34E10 e P34H3 foram os únicos que realmente apresentaram similaridade com a sequência de pha sintase:

P34F10 - 99\% de similaridade com poly(3-hydroxyalkanoic acid) synthase 1de Pseudomonas aeruginosa PAO1

GGGCGCATCCAGGCGAACACCTTGGCCATGTCCTTGCCCTCCAGCACGCCGGACTGGTAGGAACGA CGCTTGGCGGCCTCCAGAGTCTTCTCGTCGGCGAACAGCGCGACCTGGGTATTCAGTTCGAAGTCG AGCACGCTGACCAGTTGGGTGAAGGCGTTGACCTTCTTCTCGCCGCTGGCCACGTAGTGGCCGACC AGGGTCGCGGTGGTGATCCCGCCGGAGCAGGCGCCGAGGAGGTTGAGGTCTTTGCTGCCGGTGATC 
GACAGGACTACCTCGATGGCCTCCTTGAGCGCCTCGATATAGGTGGTCAGGCCCCATTCGCGCTGC GACTTGGTCGGGTTGCGCCAACTGACGATGAAGGTCTGCACGCCGTTGCGCAGG

P34E3 - 99\% de similaridade com poly(3-hydroxyalkanoic acid) synthase 1de Pseudomonas aeruginosa LESB58

CAGTAGTTCCAGATCAGGTCGTTGGGGCGCATCCAGGCGAACACCTTGGCCATGTCCTTGCCCTCC AGCACGCCGGACTGGTAGGAACGACGCTTGGCGGCCTCCAGAGTCTTCTCGTCGGCGAACAGCGC GACCTGGGTATTCAGTTCGAAGTCGAGCACGCTGACCAGTTGGGTGAAGGCGTTGACCTTCTTCTC GCCGCTGGCCACGTAGTGGCCGACCAGGGTCGCGGTGGTGATCCCGCCGGAGCAGGCGCCGAGGA GGTTGAGGTCTTTGCTGCCGGTGATCGACAGGACTACCTCGATGGCCTCCTTGAGCGCCTCGATAT AGGTGGTCAGGCCCCATTCGCGCTGCGACTTGGTCGGGTTGCGCAACTGACGATGAAGGTCTGCAC GCCGTTGCGCAGGCAGAAGCGCGCCAGGCTCTTGTCCGGCGACA

\subsection{Amplificação e sequenciamento do inserto dos clones Classe II positivos}

Os plasmídeos presentes nos clones P34F10 e P34H3, detectados previamente como positivos por gerarem amplicons indicativos da presença de genes codificadores de PHA sintase do tipo II (Fig. 24), foram submetidos a um seqüenciamento para verificar se os insertos apresentavam os genes íntegros ou seus operons. Para amplificação das regiões a serem seqüenciadas, foram utilizadas combinações de primers que se anelam a regiões do pBAC com os primers que se alinham com regiões da PHA sintase de classe II. As amplificações enviadas para seqüenciamento foram previamente verificadas em gel de agarose (Fig 22 e Fig 23). 


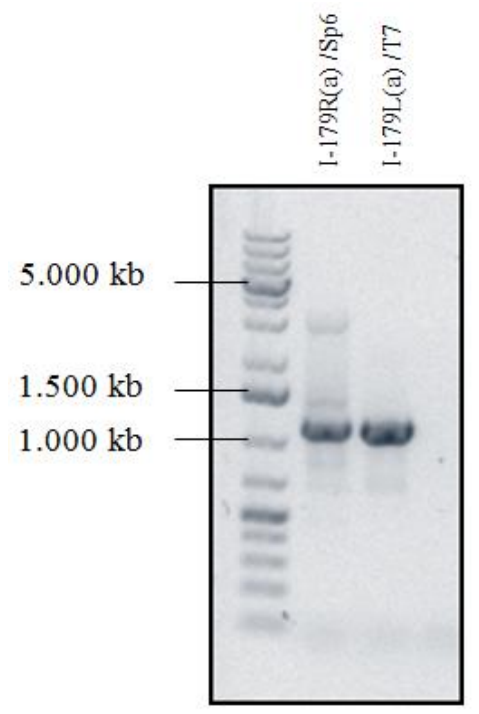

Figura 28-Perfil eletroforético em gel de agarose $0.8 \%(\mathrm{p} / \mathrm{v})$ resultante da amplificação por PCR do plasmídeo do clone P34H3, utilizando-se o par de primer

A partir do clone $\mathrm{P} 34 \mathrm{H} 3$, empregando-se os primers $\mathrm{T} 7$ e I-179L, foi obtido o seqüenciamento apresentado a seguir. Essa sequencia obtida (Seq_2) foi alinhada com a sequência da PHA sintase de Pseudomonas aeruginosa PAO1 (Seq_1). O alinhamento indica ausência das regiões inicial e terminal do gene presente do BAC.

Seq_2 do clone P34H3

GTATCGATAAGCTTGATATCGAATTCCTGCAGCCCGGGGGATCCTTTTCATCGTTCATGCACGTAGG TTCCGGGCGCGGCTTCGCCGGCCGGATAGGTCTTGTTGCCCAGGCTGGCGGGCGCCTTGCGGGTCT TGCCGGAGCGTTCGGCCAGCCATTGCTGCCAGTGCAACCACCACGAGTCGGCGTGCTTGCCGGCCT GTTCCAGCCAGGCCTTGGGCTCGGCGGGCAGTTCCGGATTGGTCATGAAGCGTGCCTTGGGGTTGC CCGGTGGGTTGAGGATGCTCTGGATGTGACCGCTGTTGGAGAGGATGAACTCGCACTTGCCACCCA GCAGCCTGGCCGACTTGTAGCACGACTCCCAGGGGGTGATGTGGTCGTTCAGACCGGCGACACAGT AGAAGTCGCAAGTCACCTGCTTCAGGTCGATGGGCGTGCCGGAGACCTCCAGGGCGCCGGGGCGG TTCAGCGGGTTGCTCTTGAACAGTTCGACGAACTCGCCGTGCAGCGCGGCGGGCAGGCGCGTGGTG TCGTTGTTCCAGTAGAGGATGTCGAACGCCGGCGGCTGGTTGCCGAGCAGGTAGTTGTTGACCCAG TAGTTCCAGATCAGGTCGTTGGGGCGCATCCAGGCGAACACCTTGGCCATGTCCTTGCCCTCCAGC ACGCCGGACTGGTAGGAACGACGCTTGGCGGCCTCCAGAGTCTTCTCGTCGGCGAACAGCGCGACC TGGGTATTCAGTTCGAAGTCGAGCACGCTGACCAGTTGGGTGAAGGCGTTGACCTTCTTCTCGCCG CTGGCCACGTAGTGGCCGACCAGGGTCGCGGTGGTGATCCCGCCGGAGCAGGCGCCGAGGAGGTT GAGGTCTTTGCTGCCGGTGATCGACAGGACTACCTCGATGGCCTCCTTGAGCGCCTCGATATAGGT 


\section{GGTCAGGCCCCATTCGCGCTGCGACTTGGTCGGGTTGCGCCAACTGACGATGAAGGTCTGCACGCC GTGCGCAGGCAGAAG}

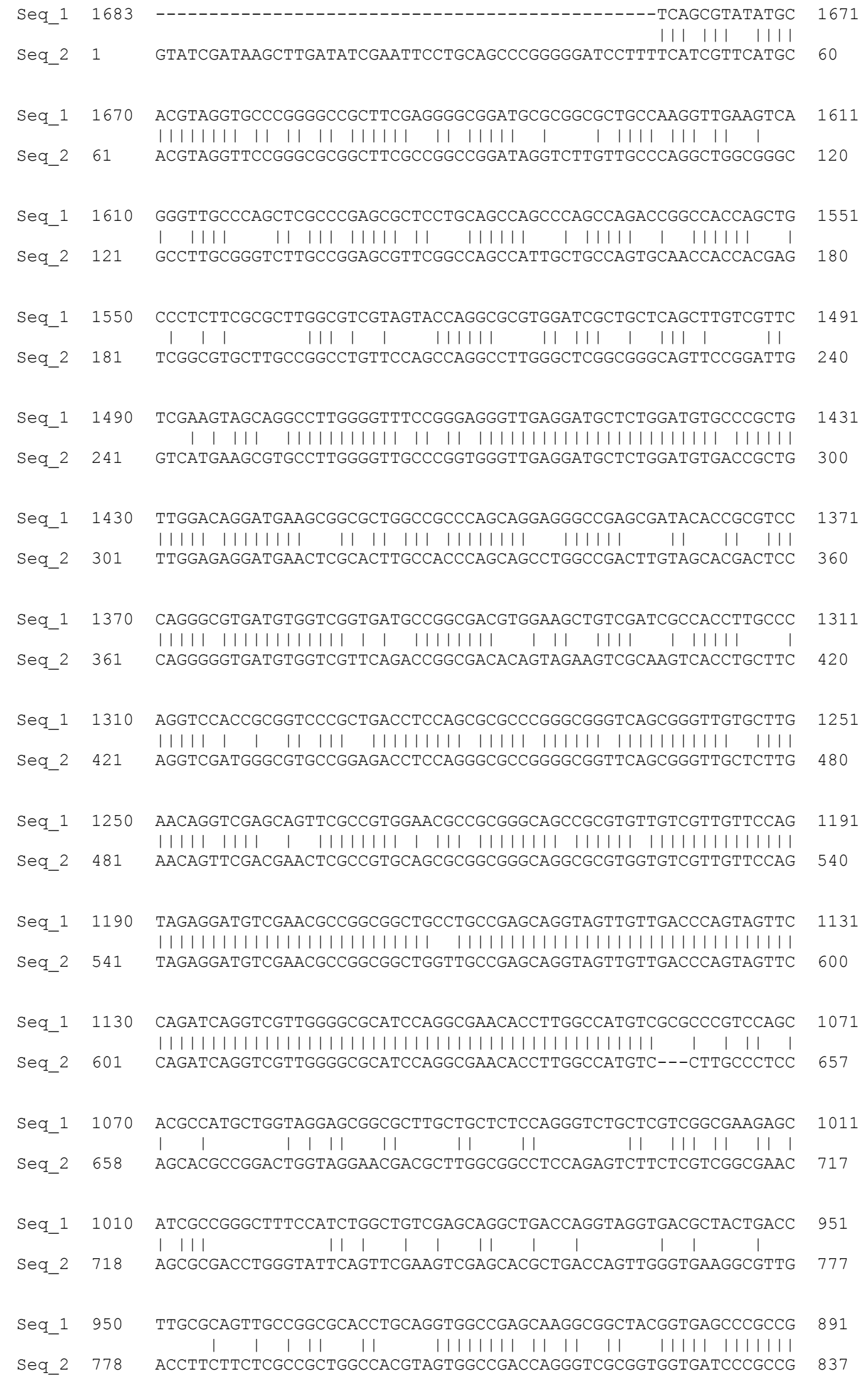


Seq_1 890 GCGCAGGCGCCGGCCAGGTTCACGCTGCGGCTGCCGGTGATCTCGCGGCTGACCTCGATG

| |||||||||| ||||| | | ||||||||||||| || |||||||||

Seq_2 838 GAGCAGGCGCCGAGGAGGTTGAGGTCTTTGCTGCCGGTGATCGACAGGACTACCTCGATG 897

831

Seq_1 830 GCCTGGTCGAGGGCCTCGACATAGGTGCTCAGGCCCATTCGCGGTGCTGGGCGTCG---

Seq_2 898 GCCTCCTTGAGCGCCTCGATATAGGTGGTCAGGCCCCATTCGCG---CTGCGACTTGGTC

954

Seq_1 773 GGGTTGCGCCAACTGATGACGAAGACCTGCAGGTTGTTCTTCAGGGCGTACTGGACGAAG

||||||||||||||||

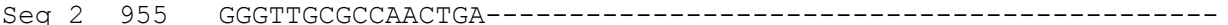

714

970

Seq_1 713 CTCTTtTCCGGCGACAGGTCGAAGATGTAGTACTTGTTGATCTGCGGCGGCACGATCAGC

654

Seq_2 971

970

Seq_1 653 AGGGGCTTGGCGTACTGGCGCTCGCCCAGCGGCTTGTACTGGATCAGCTCCAGCACCTCG

594

Seq_2 971

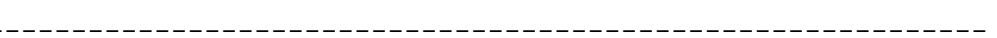

970

TTGCGGAACACCACCGCGCCTTGCGTGGTGGCGAGGTTGCGACCGATCTCGAAGGCGGTC 534

1 Seq_1 593

Seq_2 971

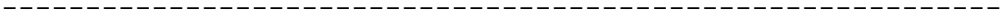

970

Seq_1 533 TTGTTCACCTGGCTGGGCATGCCGCCGTTGTGCACCAGGTCTTCGAGCAGGTGGCGGACG

474

Seq_2 971

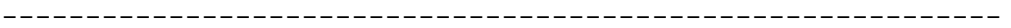

CCATTGAGCAGGCTGATCCCGCCGGTATTGAACAGTTCCTTTAACGCCAGTGGATTGATC

AGGCTGTTGCTGGGTGCCACGGCGTCGGAGAGCAAGGCGACGAGGAAGCGGGCGCGGGCG

117

118 Seq_2 971

119

120

121 Seq_1 353

122

123 Seq_2 971

124

125

126 Seq_1 293

127

128 Seq_2 975

129

130

131 Seq_1 234

132

133 Seq_2 1005

134

135

136 Seq_1 174

137

138 Seq_2 1005

139

140

141 Seq_1 114

142

143 Seq_2 1005

144

145

146 Seq_1 54 ACTCATGAACTCGGCGGGCACCGGCACGCTACCCGATTCCTGCTTTTCTCGCAT 1

147

148 seq_2 1005

-AGGTAGGCCTGCAGGGTGCGCCGGTAGAAGGGATTGAGGCGCCAGGATGGATCCTGGAA

| I |||||| || |||||

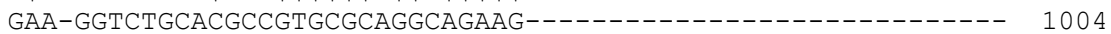

GCGGGCGTCCTGTGGGTTCGGCTGGTGCAGGGTGTCGCCCAGCAGCACCTTGCCCAACTG 175

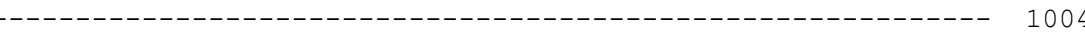

GCCTCCGAAGGCGACCAGGTGCCGCGCACTGTGCAGCGGCTGGCGCAGGCCGTGGACAGC 115

CAGGCTGCGGACCGTCGTCAGCAGGTCCTTGCCGCGCAGGCCGACGATGGCGCTCTGTGC 55 
O clone P34F10 (Fig. 24) também teve o seu DNA plasmidial parcialmente seqüenciado a partir de amplicons obtidos por combinação dos primers I179L e T7. O gel do amplicon e a sequência obtida se encontram abaixo:

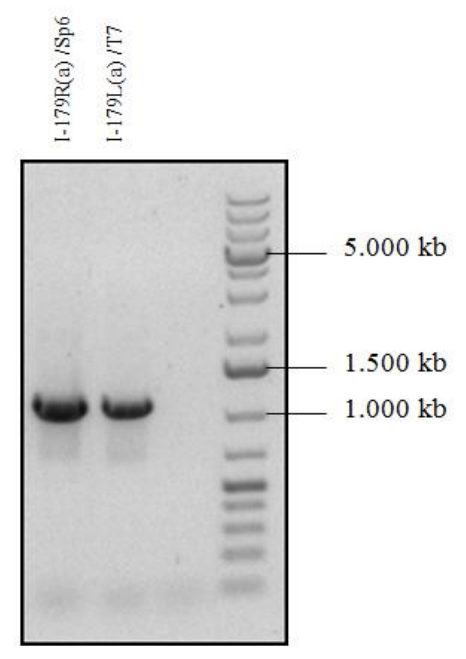

Figura 29-Perfil eletroforético em gel de agarose $0.8 \%(\mathrm{p} / \mathrm{v})$ resultante da amplificação por PCR do plasmídeo do clone P34E10, utilizando-se o par de primer I-179R(a)/Sp6 e I-179L (a)/ T7. A sequência dos primers Sp6 e T7 está presente no vetor $\mathrm{pBAC/oriV.}$

Seq_2 do clone P34F10

CRGGTCCCCTCGAGGTCGACGGTATCGATAAGCTTGATATCGAATTCCTGCAGCCCGGGGGATCCT TTYCWTCGTTCATGCACGTAGGTTCCGGGCGCGGCTTCGCCGGCCGGATAGGTCTTGTTGCCCAGG CTGGCGGGCGCCTTGCGGGTCTTGCCGGAGCGTTCGGCCAGCCATTGCTGCCAGTGCAACCACCAC GAGTCGGCGTGCTTGCCGGCCTGTTCCAGCCAGGCCTTGGGCTCGGCGGGCAGTTCCGGATTGGTC ATGAAGCGTGCCTTGGGGTTGCCCGGTGGGTTGAGGATGCTCTGGATGTGACCGCTGTTGGAGAGG ATGAACTCGCACTTGCCACCCAGCAGCCTGGCCGACTTGTAGCACGACTCCCAGGGGGTGATGTGG TCGTTCAGACCGGCGACACAGTAGAAGTCGCAAGTCACCTGCTTCAGGTCGATGGGCGTGCCGGAG ACCTCCAGGGCGCCGGGGCGGTTCAGCGGGTTGCTCTTGAACAGTTCGACGAACTCGCCGTGCAGC GCGGCGGGCAGGCGCGTGGTGTCGTTGTTCCAGTAGAGGATGTCGAACGCCGGCGGCTGGTTGCCG AGCAGGTAGTTGTTGACCCAGTAGTTCCAGATCAGGTCGTTGGGGCGCATCCAGGCGAACACCTTG GCCATGTCCTTGCCCTCCAGCACGCCGGACTGGTAGGAACGACGCTTGGCGGCCTCCAGAGTCTCT CGTCGGCGAACAGCGCGACCTGGGTATTCAGTTCGAAGTCGAGCACGCTGACCAGTTGGGKGAAG GCGTTGACTTCTTCTCGCCGCTGGCCACGTATGGCGACAGGTCGCGGTGGGTGATCCCGCGGAGCA GGCGCCGAGGAGGTGAGTCTTGCTGGCGGTGATCGAMAGACTACCTCGATGCTCTGACGCCTCGAT TAGTGTCAGTCATCGCTGCACTGGTCGTGCCCACTGACATGAGGYTGCACCCGTTGGCCAAGCG

Essa sequência também foi alinhada com o gene PHAC de Pseudomonas aeruginosa PAO1 (seq 1) 


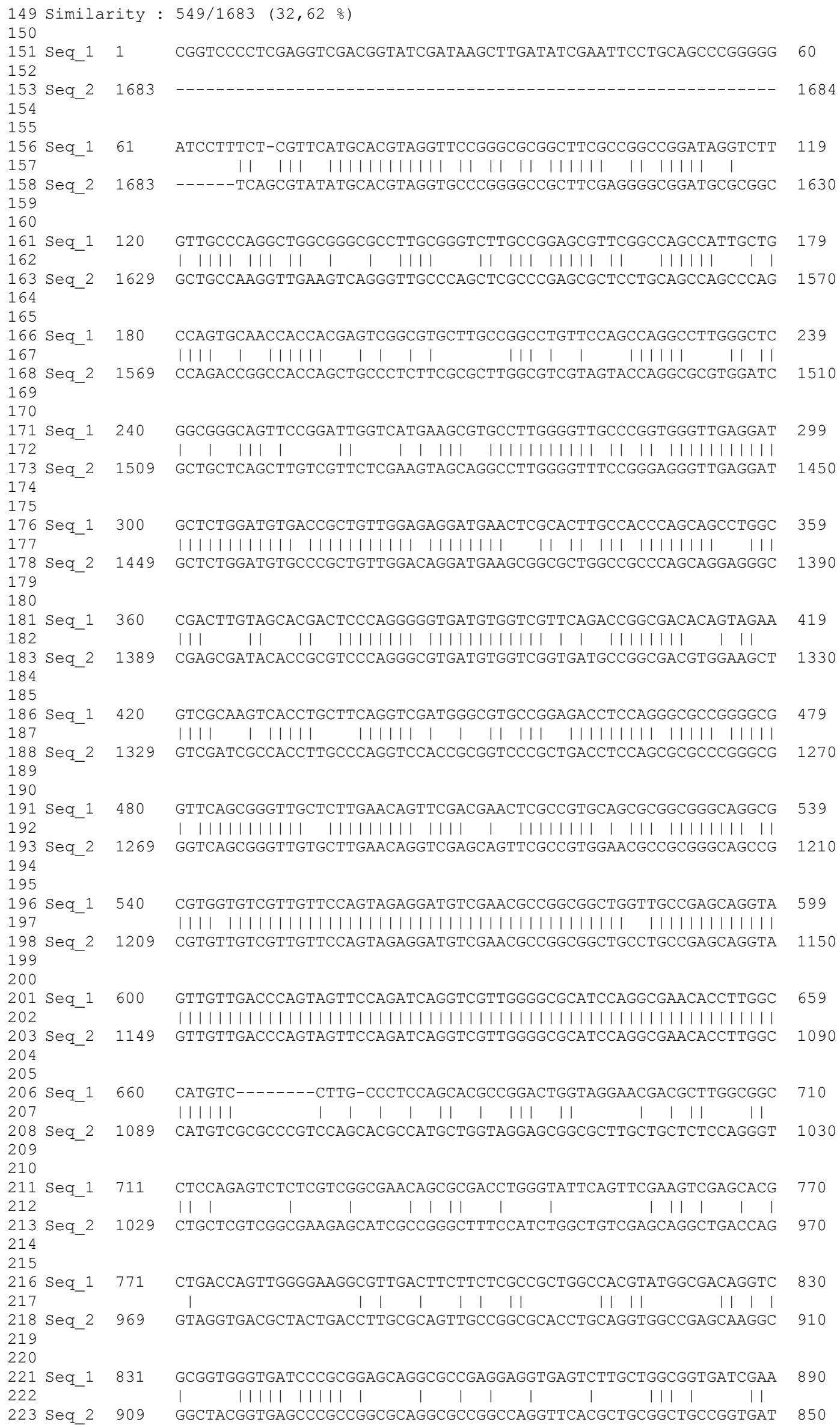


224

225

226 Seq_1 891

227

228 Seq_2 849

229

230

231 Seq_1 951

232

233 Seq_2 789

234

235

236 Seq_1 982

237

238 Seq_2 729

239

240

241 Seq_1 982

242

243 Seq_2 669

244

245

246 Seq_1 982

247

248 Seq_2 609

249

250

251 Seq_1 982

252

254

255

256 Seq_1 982

257

259

260

261 Seq_1 982

262

263 Seq_2 429

264

265

266 Seq_1 982

267

268 Seq_2 369

269

270

271 Seq_1 982

272

273 Seq_2 309

274

275

276 Seq_1 982

277

278 Seq_2 249

279

280

281 Seq_1 982

282

283 Seq_2 189

284

285

286 Seq_1 982

287

288 Seq $2 \quad 129$

289

290

291 Seq 1982

292

293 Seq 269

294

295

296 Seq_1 982

297

298 Seq_2 9
GACTACCTCGATGCTCTGACGCCTCGATTAGTGTCAGTCATCGCTGCACTGGTCGTGCCC | | | | | | | | | | | | | | | CTCGCGGCTGACCTCGATGGCCTGGTCGAGGGCCTCGACATAGGTGCTCAGGCCCCATTC 790

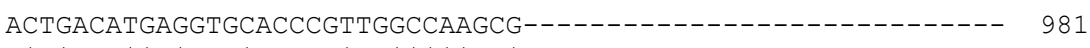


Tendo em vista que nenhum dos clones detectados como positivos para a presença de PHA sintase II possuía o gene completo, foi impossível realizar sua clonagem. Em ambos os clones que abrigavam o gene, o códon de início e de terminação estavam ausentes, o que impossibilita sua expressão.

\subsection{Detecção da presença do gene phaC em Spirulina sp e Synechococcus sp}

A PHA sintase de classe III é a menos conhecida e sua expressão em mutantes PHA negativos ainda não foi amplamente estudada. Por isso, fez-se um levantamento na literatura, buscando organismos que possuíssem esse gene, para que futuramente ele pudesse ser clonado em mutantes, assim como o plasmídeo pBluescript SK::B28+. Dentre os trabalhos que foram encontrados, muitos deles citavam Spirulina sp e Synechococcus sp como boas produtoras de PHA e como portadoras do gene phaC de classe III (MIYAKE et al., 1997; TARONCHER-OLDENBURG, NISHINA E STEPHANOPOULOS, 2000; HAI; HEIN; STEINBÜCHEL, 2001).

As duas cepas foram gentilmente doadas pelo Instituto Oceanográfico-USP. Após a preparação citada no item 2.6.8 o DNA das cianobactérias foi submetido a uma reação de PCR, utilizando os pares de primer P1/P2, Haphapcr1/2,phaE3R/F e phaC3R/F. Os resultados (figura 30) confirmam que tanto Spirulina $s p$ quanto Synechococcus $s p$, são portadoras de genes codificadores da PHA sintase de classe III. 


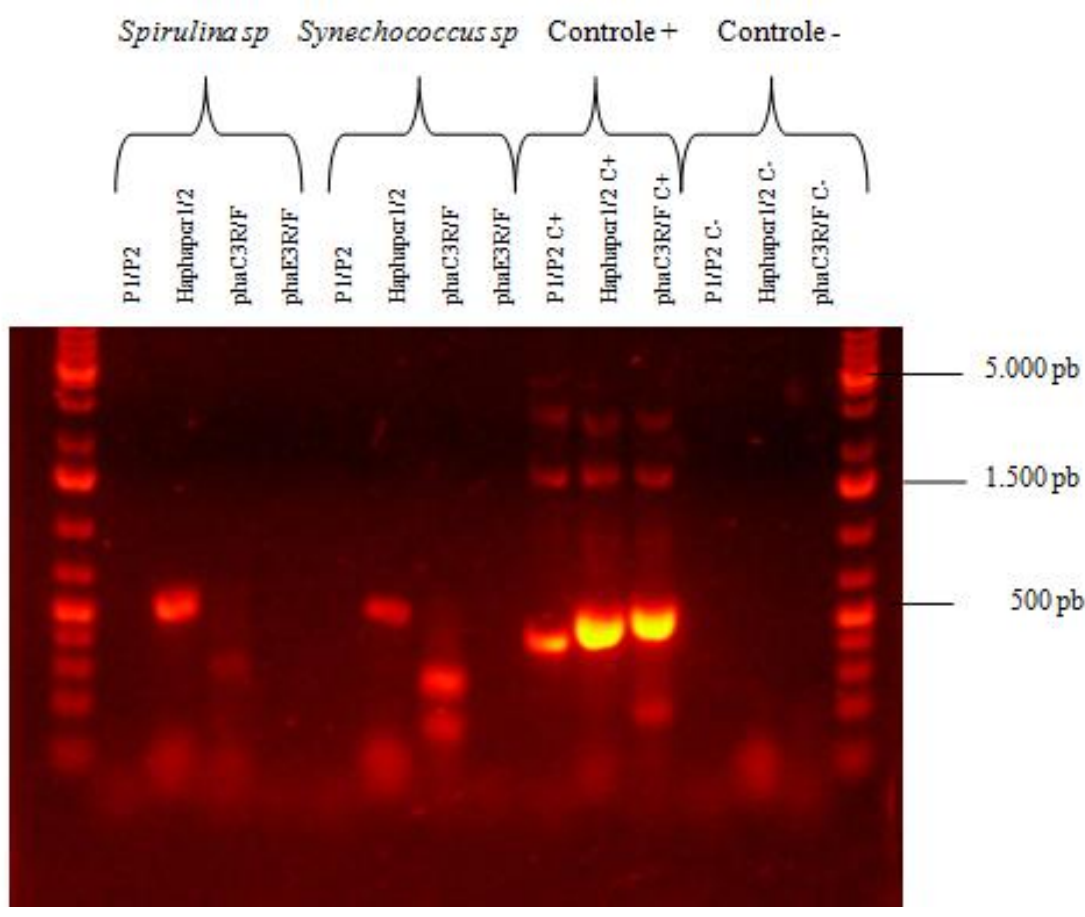

Figura 30- Eletroforese em gel de agarose $0,8 \%$, resultante da PCR das cianobactérias Spirulina sp e Synechococcus sp utilizando os pares de primer P1/P2, Haphaper1/2,phaE3R/F e phaC3R/F.O controle positivo nesse caso é plasmídeo pBluescript SK::B28+.

Os tamanhos dos amplicons do controle positivo também estão de acordo com o esperado para cada primer. Entretanto, aparentemente o primer Haphapcr1/2 foi o único que gerou um amplicon no tamanho esperado quando se utilizou o DNA das cianobactérias como "molde". Esses amplicons obtidos na reação de PCR do DNA da Spirulina sp e Synechococcus sp indicaram que ambas são portadoras da PHA sintase de classe III. Os resultados foram confirmados através do sequenciamento dos amplicons obtidos.

\section{Spirulina $\mathrm{sp}$}

GMTTGCTACGMRTACCRYWYGTGATMKGSWGAKTYRCWGMCGYKYGGGRYTTGATRTYTAYYTS ATYGATTGGGGATATCCTACCCCTGSMGATCGCTGGYTAACCCTAGGYGATTATATCTWTGGCTAT ATGAATGACTGTGTTGATTTTCTTCSCSATCACTATGAACTCCATAAAATCAACCTCCTAGGAGTTT GTCAGGGAGGAACCTTTCCCCCCTGCTTGCRKTCCCTATATCTGAAAAAGKKGCAAAACCTAATCA CCATGGTTGCSCCGGTCAACTTTRAACTGCCRAATACCCTCTTAAATGSKGGGGGAGGCTGCMCAT TGCTGACCTCACMCKKAAATATTGACCTCATGTTTGAGGSTTTWKGCTGAATCCCSCCAACTATCC CAACAGCCRGTCTTGAGGWTCWACCCCTACCTGAGGATATCWGAAATATCTCGATTTCCCGAAAT CRTGGAAAATCTTSACAAATCCTAAACTGTCTMTCATKGWMCAGKGGATMTTATWRKYCCGRA 80\% de similaridade com PHA sintase de Arthrospira platensis NIES-39

Query cover:80\%

Synechococcus sp 
GCTGCTCCTCGCGATGTCGGCCACATCCAGCATGACCACAYACTTTTGCASATTCAACCGGAACGG STTTRAGGKGAGGTARGACACATTCMGTAAATCCCCTGGAACATTGCCMAGCGCTTTCACTGKGAG GWCAGCATCCGAGTCCATCGCCCACTTGGTGAGCAAGTTATCGGAGGTTTGAAAATCSACGGGCGT CRCCMTGGKGATCAAGTTACSCACATTCTCASGGTGCGCGGCTGCWTARCAKGTGGCKAAAACGC CTCCCTGACATACACCGACCAAATTCACCTGCGGACTTTTGGTCATCKTTTTGACCTGCTCTACMCA ATCATGCARGKAGCCMAAGATGTAATCSCCTARGCTGGWAAACCGATCTGCASGGWCSGGGTAGC CCCMATCSAWGAGGKAAATATCATGSCCCGCKCGGCTCAATGCACCCRACACACTGCGGTCGTGCT GTAAGTCCATCATRTAYGGSCKRTTYACCAAMGCGTAATGAWWTWAAAAMAAA

$70 \%$ de similaridade com PHA sintase (subunidade C) de Magnetococcus marinus MC-1

É importante ressaltar que o genoma dessas cianobactérias não está totalmente sequenciado e não temos a sequência completa da PHA sintase desses gêneros.

\subsection{Confirmação da presença do gene phaC no plasmídeo pBluescript SK'::B28+}

Diante da baixa quantidade de clones positivos obtidos até este ponto, foi delineada uma nova estratégia, que consistia em buscar novas fontes de genes para a expressão heteróloga em cepas PHA negativas. Dessa forma, dois plasmídeos, descritos na literatura, foram gentilmente doados pelo Prof Steinbüchel, da Universidade Westfälische Wilhelms (Münster, Alemanha). O plasmídeo pBluescript SK::B28+ (LIEBERGESELL; RAHALKAR ; STEINBÜCHEL, 2000) contém os genes phaC e phaE de Thiocapsa pfennigii enquanto o plasmídeo pds37 contém o gene phaE e phaC de Allochromatium vinosum (Liebergesell et al., 1994; LIEBERGESELL; RAHALKAR ; STEINBÜCHEL, 2000).

Para manter o estoque dos plasmídeos ambos foram inseridos por eletroporação em $E$. coli DH5 $\alpha$, selecionando-se os clones que se tornaram resistentes a ampicilina. Destes, foi feita a extração plasmidial, cujo DNA foi posteriormente, submetido à reação de PCR para confirmar, pelo sequenciamento, a presença do gene codificador da PHA sintase desejada. Esses genes foram clonados em vetor pBBR2MCS-1 e transferidos para uma Burkholderia sacchari e Pseudomonas putida mutantes, PHA negativas e avaliar produção e a natureza do PHA gerado. Estudos anteriores (VALENTIN et al., 1994; VALENTIN; SCHONEBAUM; STEINBUCHEL, 1996) demonstraram que mutantes PHA negativas de Pseudomonas putida abrigando phaCE de Thiocapsa pfennigii foram capazes de acumular poliéster composto por $3 \mathrm{HA}_{\mathrm{SCL}}$ e $3 \mathrm{HA}_{\mathrm{MCL}}$, o que justifica nossa nova estratégia.

Para a confirmação da presença dos genes dos plasmídios recebidos, três colônias resultantes da eletroporação foram selecionadas e nomeadas TGR1, TGR2 e TGR3 ( contendo pBluescript SK::B28+ ) e uma colônia de pds37. Esses clones foram submetidos a uma amplificação diretamente de colônia (figura 31) com os 4 pares de primers descritos anteriormente para a classe III. O gene phaE não foi detectado pelo primer phaE3R/F 
(GALINDO, 2011), mas acredita-se que pode ser um problema do iniciador, uma vez que ele nunca se mostrou eficiente na amplificação desse gene.

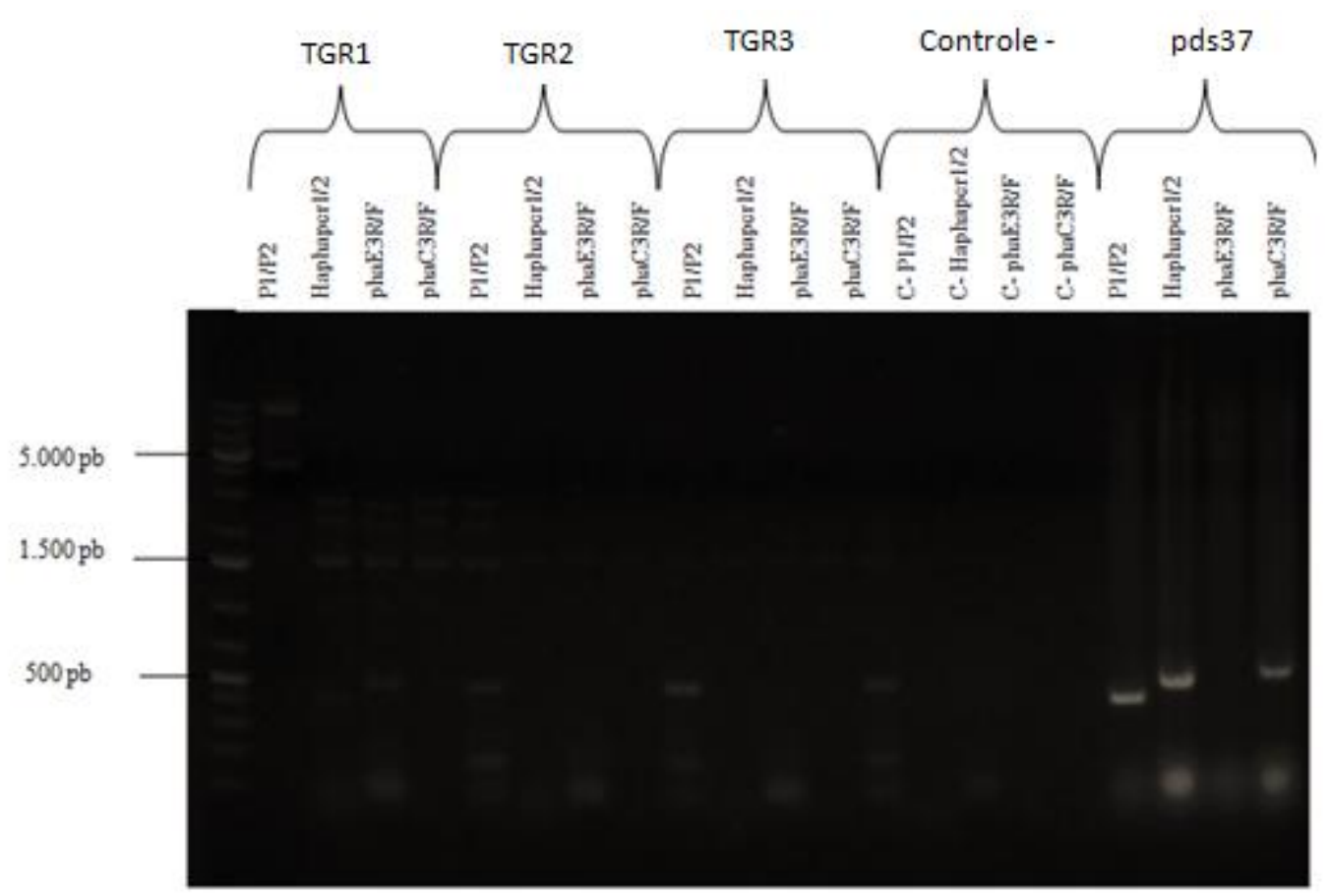

Figura 31- Perfil eletroforético em gel de agarose $0.8 \%$ (p/v) da reação de pcr das colônias TGR1, TGR2, TGR3 e pds37, com os primers P1/P2, Haphapcr1/2,phaE3R/F e phaC3R/F.

\subsection{Construção de recombinantes}

Nesta etapa foram feitos experimentos para expressar o gene phaCE de Allochromatium vinosum e de Thiocapsa pfennigii em uma linhagem Burkholderia sacchari LFM 344 (FILIPOV, 2000) e Pseudomonas sp. LFM 461 (GOMEZ, 2000a), ambas PHA negativas.

\subsection{Construção do pBBR1MCS-2 abrigando phaCE de Allochromatium vinosum}

A linhagem de E.coli que abrigava o plasmídeo pds37 foi submetida à extração plasmidial. A seguir, procedeu-se a digestão simples do plasmídeo pds37::phaCE com as enzimas de restrição EcoRI e $P v u I$ para lineariza-lo e conferir o tamanho esperado $\approx 6 \mathrm{~kb}$ e 
digestão dupla com as mesmas enzimas para a retirada o inserto, com tamanho esperado $\approx 3 \mathrm{~Kb}$ (Figura 32). O tamanho esperado do plasmídeo linearizado após a digestão com a enzima de restrição $P v u I$ foi confirmado $(6 \mathrm{~kb})$ como e possível observar na canaleta 2 e 3 . Entretanto, não foi possível realizar a retirada do inserto com a digestão dupla, pois não obteve-se a banda no tamanho esperado de $3 \mathrm{~kb}$. A partir dos resultados obtidos, em que não foi possível a remoção do gene phaCE optou-se por fazer a amplificação do mesmo, através de uma reação de PCR.

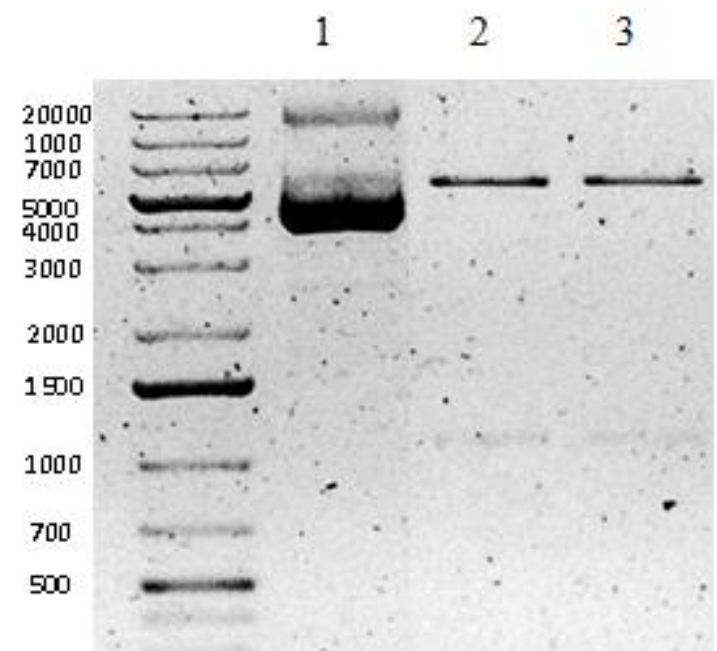

Figura 32- Perfil eletroforético dos fragmentos resultantes da digestão do plasmidio pds37::phaCE.1pds37 sem digerir, 2- Digestão simples com PvuI e 3- Digestão dupla com EcoRI e PvuI

Inicialmente, para a padronização da reação de PCR, foram empregadas diversas temperaturas de anelamento, para a verificação da temperatura mais adequada para o primer que estava sendo utilizado. Na figura 33 é possível observar que a temperatura de anelamento em que havia amplificação apenas da banda de $3 \mathrm{~kb}$, correspondente aos genes phaCE foi de $68^{\circ} \mathrm{C}$. As temperaturas mais baixas, permitiram a amplificação de bandas inespecíficas. 


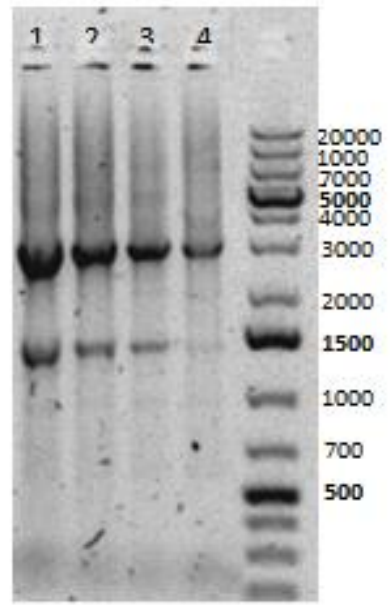

Figura 33-Perfil eletroforético dos amplicons resultantes de uma reação de PCR com diferentes temperaturas de anelamento. 1- $60^{\circ} \mathrm{C}, 2-62,8^{\circ} \mathrm{C}, 3-65.5^{\circ} \mathrm{C}$ e $4-68^{\circ} \mathrm{C}$

Com o objetivo de obter o extremidades coesivas previamente à ligação do gene amplificado acima ao plasmídeo pBBR1MCS2, ambos foram submetidos a uma digestão dupla com as enzimas de restrição EcoRI e XhoI Uma vez linearizado o plasmídeo e os genes phaCE digeridos, foi realizada a ligação, utilizando a enzima T4 ligase, para obter a construção pBBR2::phaCE.

$\mathrm{O}$ produto da ligação foi purificado previamente à eletroporação com o PCR Purification Kit da Quiagen como descrito em Materiais e Métodos. A concentração do produto purificado após medição no Nanodrop foi de $64.7 \mathrm{ng} / \mu \mathrm{l}$.

Uma vez purificado, o plasmídeo pBBRMCS-2::phaCE foi inserido por eletroporação em Burkholderia sacchari LFM 344 e Pseudomonas sp. LFM 461, as quais previamente se tornaram eletrocompetentes como o protocolo descrito em anteriormente. Os clones positivos de B. sacchari foram selecionados baseados no marcador de resistência $\left(\mathrm{Km}^{\mathrm{R}}\right)$.

Foi realizada uma PCR de colônia com vários clones positivos para confirmar a presença do inserto phaCE ( $\approx 3 \mathrm{~Kb}$ ) (fig 34). 


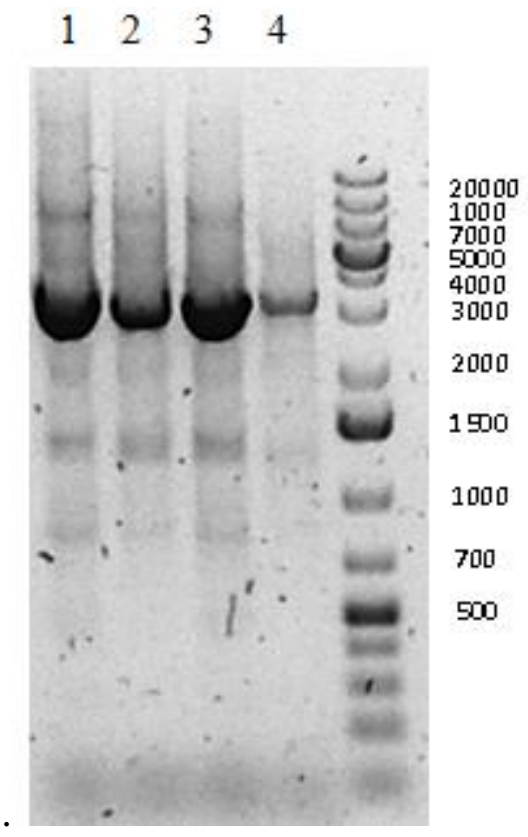

Figura 34-Perfil eletroforético resultante da amplificação do gene phaCE das colônias de B. sacchari 344 resultantes da eletroporação. Cada canaleta corresponde a um clone diferente.

Para confirmar que as colônias de B. sacchari 344 realmente estavam portando os genes phaCE, um amplicon obtido no PCR de colônia foi enviado para sequenciamento. Abaixo segue a sequência obtida, que possui $94 \%$ de similaridade com PHA sintase (subnidade E) de Allochromatium vinosum DSM 180.

Não foram obtidos clones positivos para Pseudomonas LFM 461 através da eletroporação. Então foi realizada uma conjugação como o protocolo descrito em Materias e Métodos utilizando como bactéria doadora uma linhagem de E. coli S17 portando o plasmídeo pBBRMCS-2 phaCE. Foram obtidas três colônias a partir da conjugação e todas foram utilizadas no ensaio de acúmulo.

\subsubsection{Construção do pBBR1MCS-2 abrigando phaCE de Thiocapsa pfennigii}

O resultados das reações de PCR utilizando-se o primer desenhado para a amplificação do gene phaCE de Thiocapsa pfennigii foi negativo. As temperaturas de anelamento variaram de $55^{\circ} \mathrm{C}$ e $70{ }^{\circ} \mathrm{C}$, mas em nenhuma temperatura foi possível detectar o amplicon. 
Os plasmídeos pBluescript $\mathrm{SK}^{-}:: \mathrm{B} 28+$ e pBBR1MCS-2 foram digeridos separadamente com a enzima BamHI (Fermentas $\left({ }^{2}\right)$, de acordo com as instruções do fabricante. Os produtos da digestão foram submetidos a uma corrida eletroforética em gel de agarose para confirmar o tamanho dos fragmentos obtidos. O plasmídeo tem $3 \mathrm{~kb}$ e o inserto 2850pb (Fig 35). A partir do gel de agarose, o inserto de pBluescript SK ::B28+ foi retirado e purificado (kit gel extraction QIAGEN) e ligado ao pBBR1MCS-2 digerido (Fig 36) com a enzima ligase (Thermo scientific) de acordo com as instruções do fabricante.

Uma alíquota de $1 \mu \mathrm{L}$ da ligação foi utilizada para a eletroporação em E. coli $\mathrm{Dh} 5 \alpha$, que foram semeadas em meio de cultura LB sólido contendo X-gal e IPTG para o teste de alfa complementação. As colônias brancas foram selecionadas, inferindo-se pela sua coloração que seus respectivos plasmídeos estavam abrigando o inserto. Após a seleção das colônias, seus plasmídeos (pBBR1MCS-2:: phaCE de Thiocapsa pfennigii) foram extraídos e posteriormente inseridos por eletroporação na LFM 344 e por conjugação na LFM 461, de acordo com o protoco descrito nos materiais e métodos.

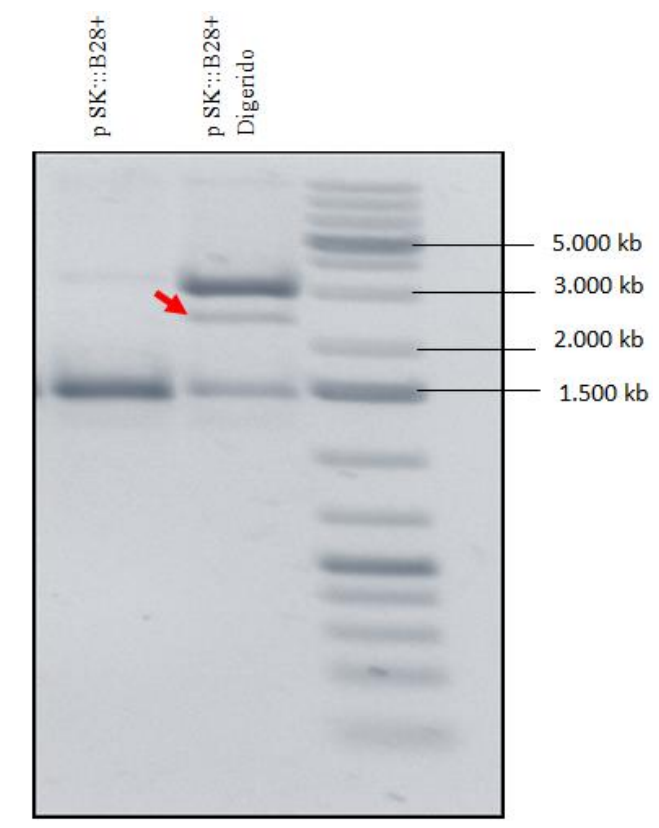

Figura 35-Perfil eletroforético em gel de agarose $0.8 \%(\mathrm{p} / \mathrm{v})$, da digestão de pBluescript SK-::B28+ com BamHI. A seta vermelha indica o inserto de 2.850 pb contendo phaC e phaE de Thiocapsa pfennigii 


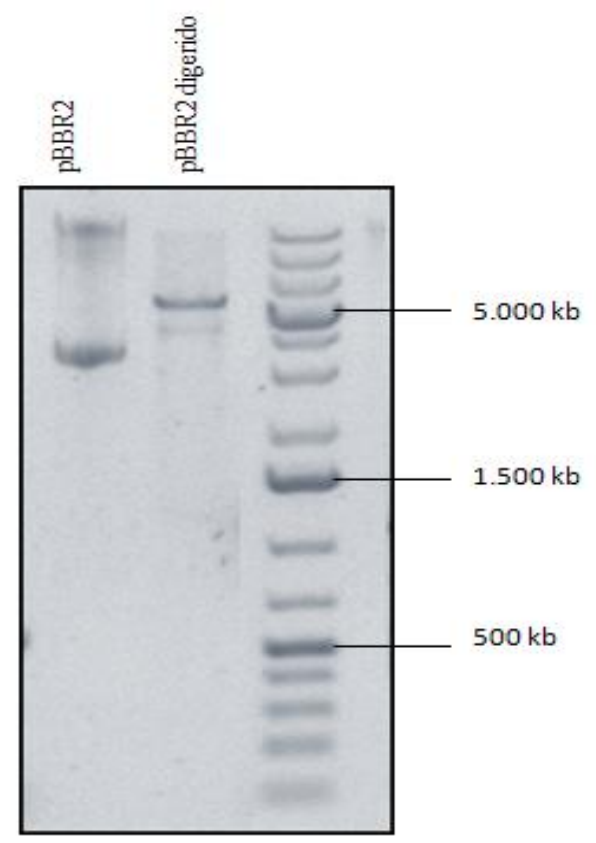

Figura 36-Perfil eletroforético em gel de agarose $0.8 \%$ (p/v), da digestão de pBBR2 com BamHI.

\subsubsection{Construção do pBBR1MCS-2 abrigando phaC de Burkholderia sacchari}

Utilizando o primer desenhado para a amplificação do gene phaC de Burkholderia sacchari, realizou-se uma reação de PCR que teve como DNA molde o DNA genômico da linhagem em questão. Para avaliar se a amplificação havia ocorrido, submeteu-se a amostra resultante da reação de PCR a uma corrida eletroforética em gel de agarose (Fig. 37), no qual foi possível visualizar a banda de aproximadamente $2000 \mathrm{pb}$. O sequenciamento do produto de PCR confirmou que se tratava do gene phaC. 


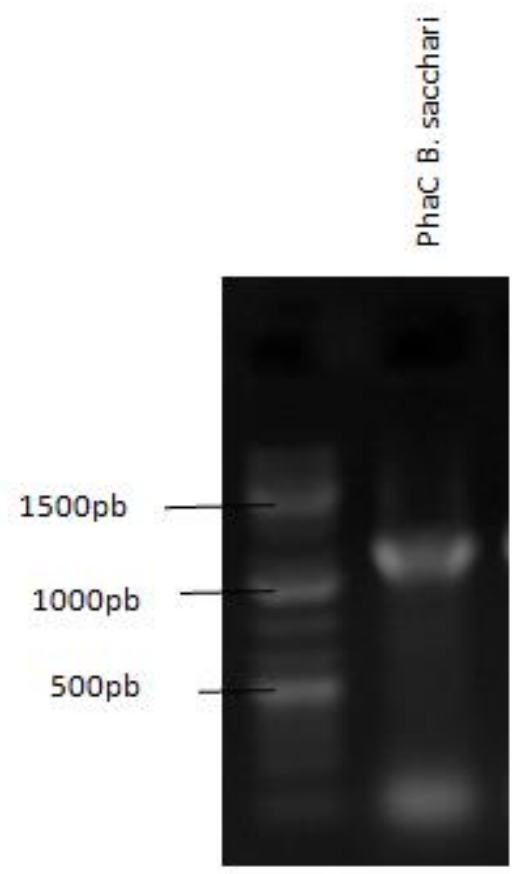

Figura 37-Perfil eletroforético em gel de agarose $0.8 \%(\mathrm{p} / \mathrm{v})$ resultante da amplificação do gene phaC de B. sacchari

\subsection{Avaliação da produção de PHA pelos recombinantes}

\subsubsection{Avaliação qualitativa da produção de PHA em meio mineral sólido}

As linhagens recombinantes de $B$. sacchari e $P$. putida obtidas foram incubadas em meio mineral sólido, contendo glicose $(10 \mathrm{~g} / \mathrm{L})$ e $(\mathrm{NH} 4) 2 \mathrm{SO}_{4}(1 \mathrm{~g} / \mathrm{L})$ como fonte de carbono durante 5 dias fornecendo assim as condições apropriadas para o acúmulo de PHA. Observou-se o resultado, baseado na coloração apresentada pelas colônias, após a utilização do corante Sudan Black. Por ser um corante lipofílico, ele reage com os grânulos de PHA, o que resulta em uma coloração azul escuro (SCHLEGEL, 1970). Quando a colônia não está produzindo PHA o corante não fixa tão bem na célula, deixando a mesma com uma coloração azul bem clara. Na figura 48B, é possível notar que a maior parte das colônias que possuem o pBBR2::phaEC de C. vinosum apresentam uma coloração bem escura, enquanto as colônias abrigando pBBR2::phaEC de T. pfennigii apresentaram coloração mais clara.Já na figura 49B é possível notar que apenas os controles positivos apresentaram coloração escura, o que indica 
que as bactérias recombinantes não estão acumulando PHA. Para fins de comparação, ambas as placas possuíam um controle positivo, que corresponde às linhagens selvagens e um controle negativo que correspondem às mutantes $\mathrm{PHA}^{-}$. Os controles positivos, como podem ser observados nas figuras 38 e 39 apresentam coloração escura, enquanto os controles negativos apresentam coloração bem clara.

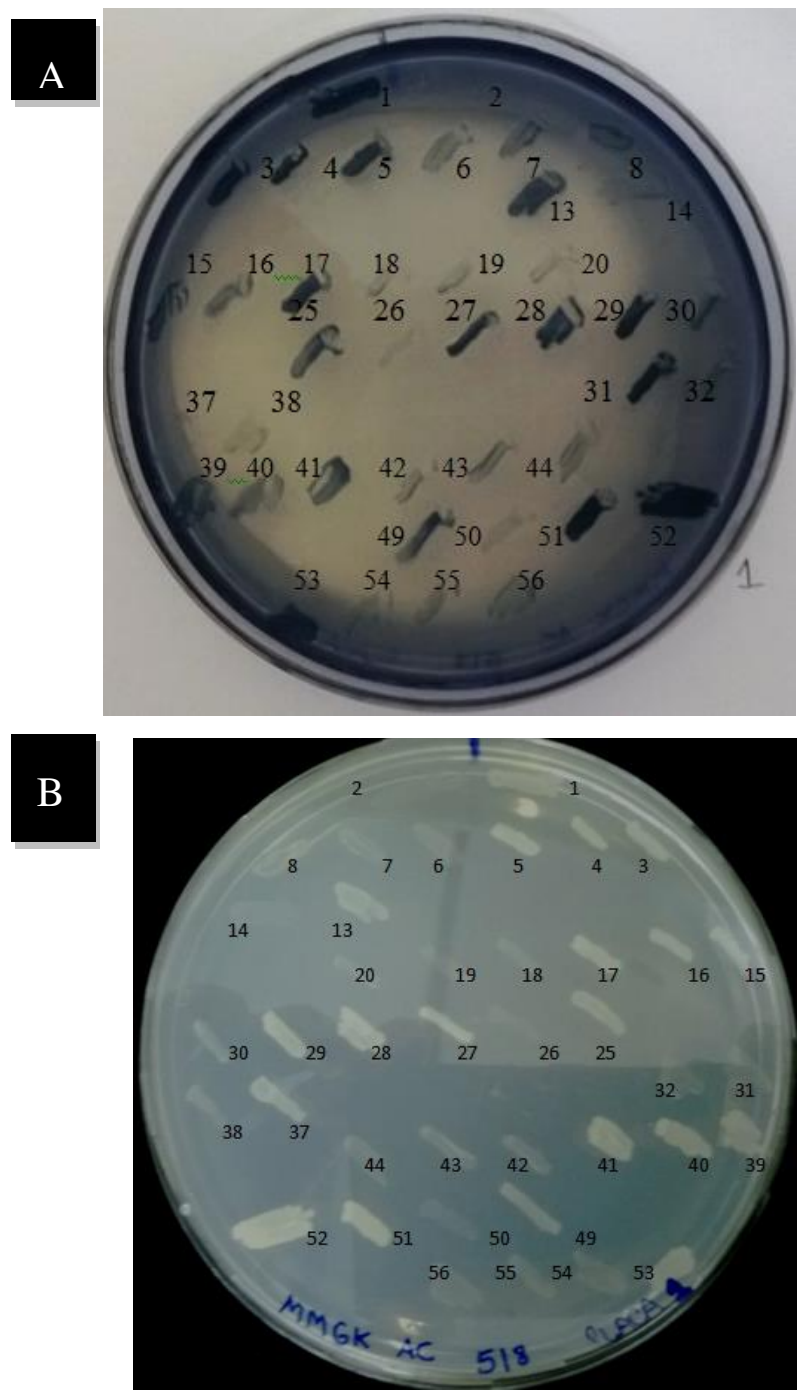

Figura 38-Avaliação da capacidade de acúmulo de polímero pelos recombinantes, em colônias coradas por Sudan Black B.

A identificação dos clones numerados na foto se encontra a seguir: 1, 13, 25, 37 e 49: Controle positivo (B. sacchari 101 com pBBR2 sem inserto)

2, 14, 26, 38 e 50: Controle negativo (B. sacchari 344 com pBBR2 sem inserto)

3, 15, 27, 39 e 51: B. sacchari 344 (pBBR2::phaEC de C. vinosum) colônia 1

4, 16, 28, 40 e 52: B. sacchari 344 (pBBR2::phaEC de C. vinosum) colônia 2

5,17, 29, 41 e 53: B.sacchari 344 (pBBR2::phaEC de C. vinosum) colônia 3 
6, 18, 30, 42 e 54: B.sacchari 344 (pBBR2::phaEC de T. pfennigii) colônia 1

7, 19, 31, 43 e 55: B. sacchari 344 (pBBR2::phaEC de T. pfennigii) colônia 2

8, 20, 32, 44 e 56: B. sacchari 344 (pBBR2::phaEC de T. pfennigii) colônia 3
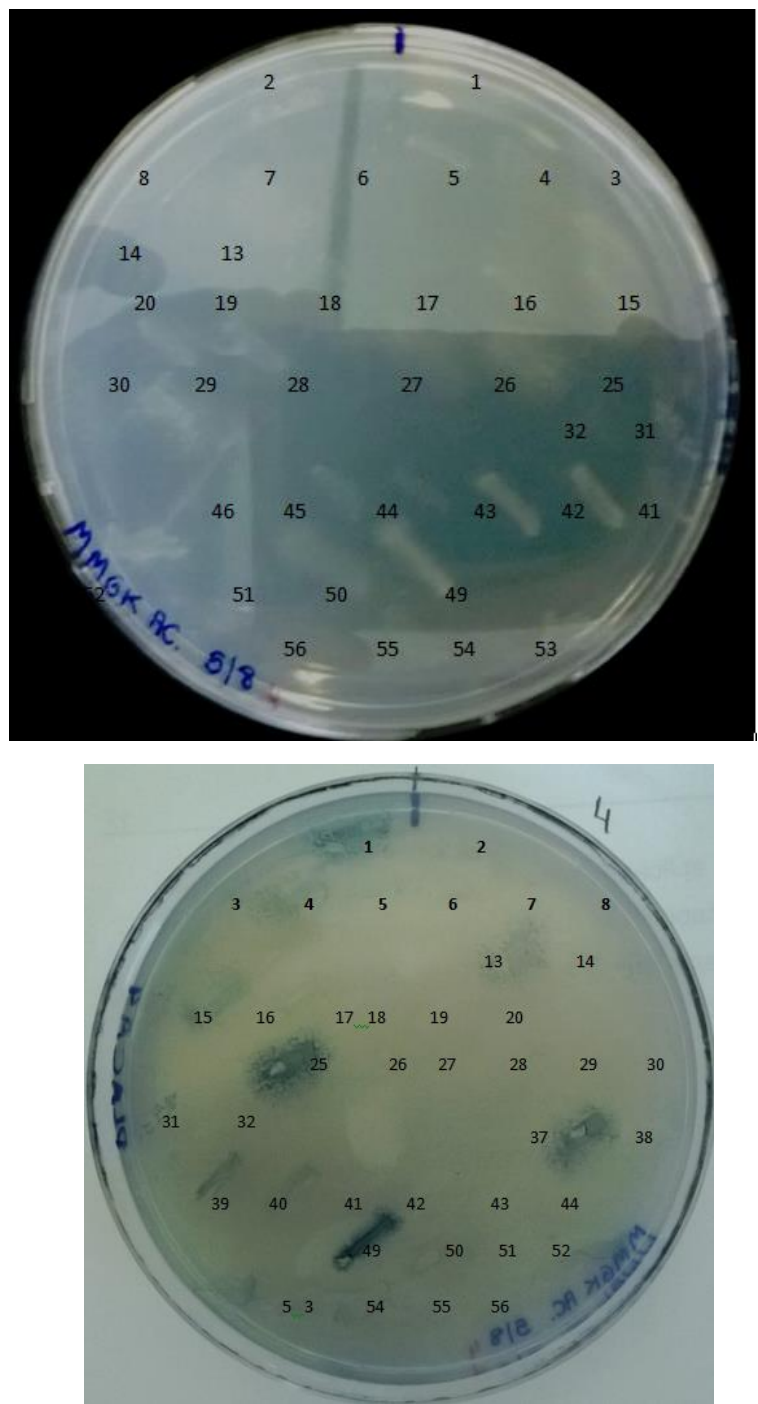

Figura 39-Avaliação da capacidade de acúmulo de polímero pelos recombinantes, em colônias coradas por Sudan Black B.

A identificação dos clones numerados na foto se encontra a seguir:

1, 13, 25, 37 e 49: Controle positivo ( $P$. putida 046 com pBBR2 vazio)

2, 14, 26, 38 e 50: Controle negativo ( $P$. putida 461 com pBBR2 vazio)

3, 15, 27, 39 e 51: P. putida 461 (pBBR2::phaEC de C. vinosum) colônia 4

4, 16, 28, 40 e 52: P. putida 461 (pBBR2::phaEC de C. vinosum) colônia 5

5, 17, 29, 41 e 53: P. putida 461 (pBBR2::phaEC de C. vinosum) colônia 6

6, 18, 30, 42 e 54: P. putida 461 (pBBR2::phaEC de T. pfennigii) colônia 4

7, 19, 31, 43 e 55: P. putida 461 (pBBR2::phaEC de T. pfennigii) colônia 5 
8, 20, 32, 44 e 56: P. putida 461 (pBBR2::phaEC de T. pfennigii) colônia 6

Por ser um teste visual, o Sudan Black tem uma certa subjetividade, entretanto é uma forma eficiente para selecionar os recombinantes mais promissores para a realização da avaliação quantitativa.

\subsubsection{Avaliação quantitativa da produção de PHA em meio mineral líquido}

Dois grupos de ensaios foram realizados: um deles utilizando glicose como única fonte de carbono e outro combinando a glicose com um ácido orgânico No primeiro grupo de experimentos, as linhagens recombinantes de B. sacchari e $P$. putida foram inoculadas em LB líquido contendo canamicina e incubadas em agitador rotativo a $30{ }^{\circ} \mathrm{C}$ por 24 horas. Após esse período, $5 \mathrm{~mL}$ do inóculo foram depositados em meio mineral com glicose $10 \mathrm{~g} / \mathrm{L}$ e canamicina. Foram retiradas amostras com 24 e 72 horas de cultivo para análise de determinação de biomassa, e PHA. Para todos os ensaios foram realizados cultivos em triplicata, conforme previamente descritos (GOMEZ et al., 1996).

O segundo grupo de experimentos foi conduzido de modo similar, com a diferença de que após 24 horas de cultivo, foi adicionado o ácido orgânico, na concentração de 1g/L e o inóculo foi mantido em agitação por mais 48 horas. Foram retiradas amostras com 24 e 72 horas de cultivo para análises posteriores (determinação de biomassa e PHA). Para todos os ensaios foram realizados cultivos em triplicata, conforme previamente descritos (GOMEZ et al., 1996). Os resultados se encontram nas tabelas a seguir: 
Tabela 12-Avaliação da capacidade de produção de PHA por recombinantes de $B$. sacchari abrigando genes codificadores de PHA sintase do tipo III, a partir de glicose (10g/L) como única fonte de carbono

\begin{tabular}{|c|c|c|c|c|c|c|c|c|c|}
\hline \multirow{3}{*}{$\begin{array}{c}\text { Linhagem/ } \\
\text { Condições de cultivo } \\
\text { LFM } 101 \text { pBBR1MCS-2 }\end{array}$} & \multirow{2}{*}{$\begin{array}{c}\text { Tempo } \\
\text { (h) }\end{array}$} & \multicolumn{2}{|c|}{$\begin{array}{l}\text { MSC } \\
(\mathrm{g} / \mathrm{L})\end{array}$} & \multicolumn{2}{|c|}{$\frac{\text { PHA }(\mathrm{mol} \%)}{3 \mathrm{HB}}$} & \multicolumn{2}{|c|}{$\begin{array}{c}\text { PHA } \\
(\% \mathrm{MSC})\end{array}$} & \multicolumn{2}{|c|}{$\begin{array}{l}\text { PHA } \\
(\mathrm{g} / \mathrm{L})\end{array}$} \\
\hline & & 4,62 & $\pm 0,1$ & 100,00 & $\pm 0,0$ & 43,30 & $\pm 4,3$ & 2,00 & $\pm 0,23$ \\
\hline & 72 & 4,90 & $+0,1$ & 100,00 & $\pm 0,0$ & 41,31 & $+6,0$ & 2,02 & $+0,25$ \\
\hline \multirow{2}{*}{ LFM 344 pBBR1MCS-2 } & 24 & 3,33 & $\pm 0,2$ & 100,00 & $\pm 0,0$ & 1,47 & $\pm 0,4$ & 0,05 & $\pm 0,01$ \\
\hline & 72 & 3,67 & $+0,1$ & 100,00 & $+0,0$ & 1,47 & $+0,4$ & 0,05 & $+0,01$ \\
\hline \multirow{2}{*}{$\begin{array}{c}\text { LFM } 344 \text { pBBR1MCS- } \\
2:: \text { phaC }_{\text {BS }}\end{array}$} & 24 & 4,20 & $\pm 0,2$ & 100,00 & $\pm 0,0$ & 39,27 & $\pm 4,9$ & 1,65 & $\pm 0,27$ \\
\hline & 72 & 4,61 & $+0,0$ & 100,00 & $+0,0$ & 26,91 & $+3,5$ & 1,24 & $+0,16$ \\
\hline \multirow{2}{*}{$\begin{array}{c}\text { LFM } 344 \text { pBBR1MCS- } \\
2:: p_{\text {phaCV }}\end{array}$} & 24 & 4,90 & $\pm 0,3$ & 100,00 & $\pm 0,0$ & 46,10 & $\pm 4,7$ & 2,25 & $\pm 0,17$ \\
\hline & 72 & 5,11 & $+0,3$ & 100,00 & $+0,0$ & 40,65 & $\begin{array}{r}- \\
+6,7 \\
\end{array}$ & 2,09 & $\begin{array}{r}- \\
+0,47 \\
\end{array}$ \\
\hline \multirow{2}{*}{$\begin{array}{c}\text { LFM } 344 \text { pBBR1MCS- } \\
\text { 2::phaC } \mathrm{Tp}_{\mathrm{p}}\end{array}$} & 24,00 & 2,15 & $\pm 0,60$ & 0,00 & $\pm 0,00$ & 0,00 & $\pm 0,00$ & 0,00 & $\pm 0,00$ \\
\hline & 72,00 & 3,45 & $\pm 0,42$ & 0,00 & $+0,00$ & 0,00 & $\pm 0,00$ & 0,00 & $\pm 0,00$ \\
\hline
\end{tabular}

MSC - Massa seca celular, 3HB- 3-hidroxibutirato 
Tabela 13-Avaliação da capacidade de produção de PHA por B. sacchari LFM 101 abrigando o plasmídeo pBBR1-MSC2, a partir de glicose (10g/L) e ácidos orgânicos $(1 \mathrm{~g} / \mathrm{L})$.

\begin{tabular}{|c|c|c|c|c|c|c|c|c|c|c|c|c|c|c|c|}
\hline \multirow{4}{*}{$\begin{array}{c}\text { Fonte de carbono } \\
\text { Glicose + propanoato }\end{array}$} & \multirow{3}{*}{$\begin{array}{c}\text { Tempo } \\
\text { (h) } \\
24\end{array}$} & \multirow{2}{*}{\multicolumn{2}{|c|}{$\overline{\mathrm{pH}}$}} & \multirow{2}{*}{\multicolumn{2}{|c|}{$\begin{array}{l}\text { MSC } \\
(\mathrm{g} / \mathrm{L})\end{array}$}} & \multicolumn{6}{|c|}{ PHA (mol\%) } & \multirow{2}{*}{\multicolumn{2}{|c|}{$\begin{array}{c}\text { PHA } \\
(\% \mathrm{MSC})\end{array}$}} & \multirow{2}{*}{\multicolumn{2}{|c|}{$\begin{array}{l}\text { PHA } \\
(\mathrm{g} / \mathrm{L})\end{array}$}} \\
\hline & & & & & & \multicolumn{2}{|c|}{ 3HB } & \multicolumn{2}{|c|}{ 3HV } & \multicolumn{2}{|c|}{$3 H H x$} & & & & \\
\hline & & 6,14 & $\pm 0,08$ & 2,64 & $\pm 0,05$ & 100,00 & $\pm 0,00$ & 0,00 & $\pm 0,00$ & 0,00 & $\pm 0,00$ & 43,89 & $\pm 2,48$ & 1,15 & $\pm 0,06$ \\
\hline & 72 & 7,28 & $\pm 0,01$ & 5,13 & $\pm 0,30$ & 95,21 & $\pm 0,58$ & 4,78 & $\pm 0,59$ & 0,00 & $\pm 0,00$ & 45,50 & $\pm 9,75$ & 2,34 & $\pm 0,59$ \\
\hline \multirow{2}{*}{ Glicose + butirato } & 24 & 6,02 & $\pm 0,03$ & 2,46 & $\pm 0,07$ & 100,00 & $\pm 0,00$ & 0,00 & $\pm 0,00$ & 0,00 & $\pm 0,00$ & 40,14 & $\pm 1,41$ & 0,98 & $\pm 0,00$ \\
\hline & 72 & 7,34 & $\pm 0,01$ & 5,17 & $\pm 0,05$ & 100,00 & $\pm 0,00$ & 0,00 & $\pm 0,00$ & 0,00 & $\pm 0,00$ & 42,29 & $\pm 1,55$ & 2,18 & $\pm 0,09$ \\
\hline \multirow{2}{*}{ Glicose + valerato } & 24 & 6,05 & $\pm 0,07$ & 2,92 & $\pm 0,28$ & 100,00 & $\pm 0,00$ & 0,00 & $\pm 0,00$ & 0,00 & $\pm 0,00$ & 42,71 & $\pm 1,83$ & 1,24 & $\pm 0,07$ \\
\hline & 72 & 7,20 & $\pm 0,01$ & 5,12 & $\pm 0,05$ & 88,31 & $\pm 0,67$ & 11,69 & $\pm 0,67$ & 0,00 & $\pm 0,00$ & 44,52 & $\pm 4,79$ & 2,28 & $\pm 0,26$ \\
\hline \multirow{2}{*}{ Glicose + hexanoato } & 24 & 6,16 & $\pm 0,21$ & 2,43 & $\pm 0,10$ & 100,00 & $\pm 0,00$ & 0,00 & $\pm 0,00$ & 0,00 & $\pm 0,00$ & 41,53 & $\pm 0,97$ & 1,01 & $\pm 0,05$ \\
\hline & 72 & 7,08 & $\pm 0,02$ & 4,93 & $\pm 0,19$ & 99,70 & $\pm 0,06$ & 0,00 & $\pm 0,00$ & 0,30 & $\pm 0,06$ & 31,23 & $\pm 5,85$ & 1,53 & $0 \pm /, 23$ \\
\hline \multirow{2}{*}{ Glicose + heptanoato } & 24 & 5,40 & $\pm 0,05$ & 3,50 & $\pm 0,26$ & 100,00 & $\pm 0,00$ & 0,00 & $\pm 0,00$ & 0,00 & $\pm 0,00$ & 27,70 & $\pm 2,64$ & 0,96 & $\pm 0,01$ \\
\hline & 72 & 4,40 & $\pm 0,06$ & 4,93 & $\pm 0,11$ & 63,92 & $\pm 3,54$ & 36,07 & $\pm 3,54$ & 0,00 & $\pm 0,00$ & 4,02 & $\pm 0,44$ & 0,20 & $\pm 0,01$ \\
\hline \multirow{2}{*}{ Glicose + octanoato } & 24 & 5,37 & $\pm 0,03$ & 2,33 & $\pm 0,80$ & 100,00 & $\pm 0,00$ & 0,00 & $\pm 0,00$ & 0,00 & $\pm 0,00$ & 28,88 & $\pm 2,46$ & 0,67 & $\pm 0,27$ \\
\hline & 72 & 6,77 & $\pm 0,11$ & 4,74 & $\pm 0,19$ & 100,00 & $\pm 0,00$ & 0,00 & $\pm 0,00$ & 0,00 & $\pm 0,00$ & 20,26 & $\pm 6,99$ & 0,96 & $\pm 0,31$ \\
\hline \multirow{2}{*}{ Glicose + nonanoato } & 24 & 5,55 & $\pm 0,11$ & 3,87 & $\pm 0,09$ & 100,00 & $\pm 0,00$ & 0,00 & $\pm 0,00$ & 0,00 & $\pm 0,00$ & 34,40 & $\pm 7,58$ & 1,33 & $\pm 0,28$ \\
\hline & 72 & 6,82 & $\pm 0,14$ & 4,39 & $\pm 0,47$ & 82,08 & $\pm 4,20$ & 17,92 & $\pm 4,20$ & 0,00 & $\pm 0,00$ & 37,84 & $\pm 14,97$ & 1,69 & $\pm 0,75$ \\
\hline
\end{tabular}

MSC - Massa seca celular, 3HB- 3-hidroxibutirato, 3H - 3-hidroxivalerato 3HHx - 3-hidroxihexanoato, 
Tabela 14-Avaliação da capacidade de produção de PHA por $B$. sacchari LFM 344 abrigando o gene phaC de $B$. sacchari , a partir de glicose (10g/L) e ácidos orgânicos (1g/L).

\begin{tabular}{|c|c|c|c|c|c|c|c|c|c|c|c|c|c|c|c|}
\hline \multirow{4}{*}{$\begin{array}{c}\text { Fonte de carbono } \\
\text { Glicose + propanoato }\end{array}$} & \multirow{3}{*}{$\begin{array}{c}\text { Tempo } \\
\text { (h) } \\
24\end{array}$} & \multirow{2}{*}{\multicolumn{2}{|c|}{$\mathrm{pH}$}} & \multirow{2}{*}{\multicolumn{2}{|c|}{$\begin{array}{l}\text { MSC } \\
(g / L)\end{array}$}} & \multicolumn{6}{|c|}{ PHA (mol\%) } & \multirow{2}{*}{\multicolumn{2}{|c|}{$\begin{array}{c}\text { PHA } \\
(\% \text { MSC })\end{array}$}} & \multirow{2}{*}{\multicolumn{2}{|c|}{$\begin{array}{l}\text { PHA } \\
(\mathrm{g} / \mathrm{L})\end{array}$}} \\
\hline & & & & & & \multicolumn{2}{|c|}{$3 \mathrm{HB}$} & \multicolumn{2}{|c|}{$3 H V$} & \multicolumn{2}{|c|}{$3 H H x$} & & & & \\
\hline & & 6,41 & $\pm 0,00$ & 2,46 & $\pm 0,09$ & 100,00 & $\pm 0,00$ & 0,00 & $\pm 0,00$ & 0,00 & $\pm 0,00$ & 41,70 & $\pm 4,23$ & 1,02 & $\pm 0,07$ \\
\hline & 72 & 7,26 & $\pm 0,01$ & 4,69 & $\pm 0,17$ & 96,53 & $\pm 0,36$ & 3,46 & $\pm 0,36$ & 0,00 & $\pm 0,00$ & 30,67 & $\pm 1,83$ & 1,44 & $\pm 0,12$ \\
\hline \multirow{2}{*}{ Glicose + butirato } & 24 & 6,39 & $\pm 0,01$ & 2,51 & $\pm 0,27$ & 100,00 & $\pm 0,00$ & 0,00 & $\pm 0,00$ & 0,00 & $\pm 0,00$ & 38,64 & $\pm 6,88$ & 0,98 & $\pm 0,27$ \\
\hline & 72 & 7,30 & $\pm 0,02$ & 4,63 & $\pm 0,08$ & 100,00 & $\pm 0,00$ & 0,00 & $\pm 0,00$ & 0,00 & $\pm 0,00$ & 34,76 & $\pm 2,58$ & 1,61 & $\pm 0,09$ \\
\hline \multirow{2}{*}{ Glicose + valerato } & 24 & 6,38 & $\pm 0,01$ & 2,31 & $\pm 0,02$ & 100,00 & $\pm 0,00$ & 0,00 & $\pm 0,00$ & 0,00 & $\pm 0,00$ & 37,75 & $\pm 2,32$ & 0,87 & $\pm 0,04$ \\
\hline & 72 & 7,19 & $\pm 0,02$ & 4,14 & $\pm 0,03$ & 84,41 & $\pm 1,31$ & 15,59 & $\pm 1,31$ & 0,00 & $\pm 0,00$ & 28,95 & $\pm 0,84$ & 1,20 & $\pm 0,03$ \\
\hline \multirow{2}{*}{ Glicose + hexanoato } & 24 & 6,38 & $\pm 0,01$ & 2,44 & $\pm 0,11$ & 100,00 & $\pm 0,00$ & 0,00 & $\pm 0,00$ & 0,00 & $\pm 0,00$ & 38,60 & $\pm 3,43$ & 0,94 & $\pm 0,08$ \\
\hline & 72 & 7,10 & $\pm 0,01$ & 3,96 & $\pm 0,14$ & 99,59 & $\pm 0,13$ & 0,00 & $\pm 0,00$ & 0,41 & $\pm 0,13$ & 22,15 & $\pm 1,53$ & 0,88 & $\pm 0,04$ \\
\hline \multirow{2}{*}{ Glicose + heptanoato } & 24 & 4,40 & $\pm 0,06$ & 2,17 & $\pm 0,05$ & 100,00 & $\pm 0,00$ & 0,00 & $\pm 0,00$ & 0,00 & $\pm 0,00$ & 34,96 & $\pm 3,37$ & 0,76 & $\pm 0,08$ \\
\hline & 72 & 5,84 & $\pm 0,08$ & 3,41 & $\pm 0,34$ & 69,39 & $\pm 5,42$ & 30,61 & $\pm 5,42$ & 0,00 & $\pm 0,00$ & 55,49 & $\pm 0,25$ & 1,89 & $\pm 0,01$ \\
\hline \multirow{2}{*}{ Glicose + octanoato } & 24 & 5,72 & $\pm 0,20$ & 2,07 & $\pm 0,15$ & 100,00 & $\pm 0,00$ & 0,00 & $\pm 0,00$ & 0,00 & $\pm 0,00$ & 37,63 & $\pm 9,72$ & 0,77 & $\pm 0,16$ \\
\hline & 72 & 6,81 & $\pm 0,50$ & 3,14 & $\pm 0,37$ & 100,00 & $\pm 0,00$ & 0,00 & $\pm 0,00$ & 0,00 & $\pm 0,00$ & 14,74 & $\pm 13,22$ & 0,44 & $\pm 0,38$ \\
\hline \multirow{2}{*}{ Glicose + nonanoato } & 24 & 5,59 & $\pm 0,49$ & 2,60 & $\pm 0,52$ & 100,00 & $\pm 0,00$ & 0,00 & $\pm 0,00$ & 0,00 & $\pm 0,00$ & 35,47 & $\pm 4,03$ & 0,91 & $\pm 0,14$ \\
\hline & 72 & 6,65 & $\pm 0,19$ & 3,00 & $\pm 0,19$ & 97,23 & $\pm 0,64$ & 2,76 & $\pm 0,64$ & 0,00 & $\pm 0,00$ & 9,44 & $\pm 0,17$ & 0,28 & $\pm 0,01$ \\
\hline
\end{tabular}

MSC - Massa seca celular, 3HB- 3-hidroxibutirato, 3HV - 3-hidroxivalerato 3HHx - 3-hidroxihexanoato, 
Tabela 15-Avaliação da capacidade de produção de PHA por B. sacchari LFM 344 abrigando o gene phaEC de Allochromatium vinosum , a partir de glicose $(10 \mathrm{~g} / \mathrm{L})$ e ácidos orgânicos $(1 \mathrm{~g} / \mathrm{L})$.



MSC - Massa seca celular, 3HB- 3-hidroxibutirato, 3HV - 3-hidroxivalerato 3HHx - 3-hidroxihexanoato, 
Tabela 16-Avaliação da capacidade de produção de PHA por recombinantes de Pseudomonas putida abrigando genes codificadores de PHA sintase do tipo III, a partir de glicose $(10 \mathrm{~g} / \mathrm{L})$ como única fonte de carbono

\begin{tabular}{|c|c|c|c|c|c|c|c|c|c|c|c|c|c|c|c|c|c|c|}
\hline \multirow{3}{*}{$\begin{array}{c}\text { Linhagem/ } \\
\text { Condições de cultivo } \\
\text { LFM } 046 \text { pBBR1MCS-2 }\end{array}$} & \multirow{2}{*}{\multicolumn{2}{|c|}{$\begin{array}{l}\text { MSC } \\
(\mathrm{g} / \mathrm{L})\end{array}$}} & \multicolumn{12}{|c|}{ Composição PHA Mol\% } & \multirow{2}{*}{\multicolumn{2}{|c|}{$\begin{array}{c}\text { PHA } \\
\text { (\%MSC) }\end{array}$}} & \multirow{2}{*}{\multicolumn{2}{|c|}{$\begin{array}{l}\text { PHA } \\
(\mathrm{g} / \mathrm{L})\end{array}$}} \\
\hline & & & \multicolumn{2}{|c|}{$3 \mathrm{HB}$} & \multicolumn{2}{|c|}{ 3HHx } & \multicolumn{2}{|c|}{$3 \mathrm{HO}$} & \multicolumn{2}{|c|}{$3 \mathrm{HN}$} & \multicolumn{2}{|c|}{ 3HD } & \multicolumn{2}{|c|}{ 3HDd } & & & & \\
\hline & 2,85 & $\pm 0,05$ & 0,00 & $\pm 0,0$ & 0,0 & $\pm 0,0$ & 34,2 & $\pm 0,4$ & 0,0 & $\pm 0,0$ & 65,8 & $\pm 0,4$ & 0,0 & $\pm 0,0$ & 19,23 & $\pm 1,9$ & 0,55 & $\pm 0,06$ \\
\hline LFM 461 pBBR1MCS-2 & 2,72 & $\pm 0,1$ & 0,00 & $\pm 0,0$ & 0,0 & $\pm 0,0$ & 0,0 & $\pm 0,0$ & 0,0 & $\pm 0,0$ & 0,0 & $\pm 0,0$ & 0,0 & $\pm 0,0$ & 0,00 & $\pm 0,0$ & 0 & \pm 0 \\
\hline $\begin{array}{c}\text { LFM } 461 \text { pBBR1MCS- } \\
\text { 2::phaCBS }\end{array}$ & 2,14 & $\pm 0,1$ & 67,07 & $\pm 7,1$ & 8,0 & $\pm 4,5$ & 0,0 & $\pm 0,0$ & 0,0 & $\pm 0,0$ & 8,9 & $\pm 0,9$ & 16,0 & $\pm 2,2$ & 2,61 & $\pm 0,3$ & 0,06 & \pm 0 \\
\hline $\begin{array}{c}\text { LFM } 3461 \text { pBBR1MCS- } \\
2:: \text { phaCCV }\end{array}$ & 5,42 & $\pm 0,0$ & 0,00 & $\pm 0,0$ & 9,1 & $\pm 1,2$ & 0,0 & $\pm 0,0$ & 8,8 & $\pm 4,1$ & 36,3 & $\pm 1,9$ & 45,8 & $\pm 2,8$ & 2,27 & $\pm 0,1$ & 0,12 & $\pm 0,01$ \\
\hline $\begin{array}{c}\text { LFM } 461 \text { pBBR1MCS- } \\
2:: \mathrm{phaC}_{\mathrm{Tp}}\end{array}$ & 2,05 & $+0,05$ & 0,00 & $\pm 0,00$ & 0,00 & $\pm 0,00$ & 0,00 & $\pm 0,00$ & 0,00 & $\pm 0,00$ & 0,00 & $\pm 0,00$ & 0,00 & $\pm 0,00$ & 0,00 & $\pm 0,00$ & 0,00 & $\pm 0,00$ \\
\hline
\end{tabular}

MSC - Massa seca celular · 3HB - 3-hidroxibutirato $\cdot 3 \mathrm{HHx}$ - 3-hidroxihexanoato $\cdot 3 \mathrm{HO}$ - 3-hidroxioctanoato $\cdot$ 3HD - 3-hidroxidecanoato $\cdot$ 3HDd - 3-hidroxidodecanoato. 
Tabela 17-Análise da concentração de ácidos orgânicos nas diferentes linhagens, com 24 e 72 horas de cultivo

\begin{tabular}{|c|c|c|c|c|c|c|c|c|c|c|c|}
\hline $\begin{array}{c}\text { Linhagem/ } \\
\text { Condições de cultivo }\end{array}$ & $\begin{array}{c}\text { Tempo } \\
\text { (h) }\end{array}$ & \multicolumn{2}{|c|}{$\begin{array}{c}\text { Propanoato } \\
(\mathrm{g} / \mathrm{L})\end{array}$} & \multicolumn{2}{|c|}{$\begin{array}{c}\text { Butanoato } \\
(\mathrm{g} / \mathrm{L})\end{array}$} & \multicolumn{2}{|c|}{$\begin{array}{c}\text { Valerato } \\
\text { (g/L) }\end{array}$} & \multicolumn{2}{|c|}{$\begin{array}{c}\text { Hexanoato } \\
\text { (g/L) }\end{array}$} & \multicolumn{2}{|c|}{$\begin{array}{c}\text { Heptanoato } \\
(\mathrm{g} / \mathrm{L})\end{array}$} \\
\hline \multirow{2}{*}{ LFM 101 pBBR1MCS-2 } & 24 & 0,44 & 0,00 & 0,87 & 0,36 & 0,72 & 0,10 & 0,97 & 0,33 & 1,39 & 0,15 \\
\hline & 72 & 0,00 & 0,00 & 0,00 & 0,00 & 0,00 & 0,00 & 0,00 & 0,00 & 0,00 & 0,00 \\
\hline \multirow{2}{*}{ LFM 344 pBBR1MCS-2::phaC ${ }_{B S}$} & 24 & 0,72 & 1,17 & 0,90 & 1,17 & 0,86 & 0,16 & 0,69 & 0,09 & 1,30 & 0,06 \\
\hline & 72 & 0,00 & 0,00 & 0,00 & 0,00 & 0,00 & 0,00 & 0,00 & 0,00 & 0,00 & 0,00 \\
\hline \multirow{2}{*}{ LFM 344 pBBR1MCS-2::phaCCV } & 24 & 0,64 & 0,02 & 0,78 & 0,08 & 0,65 & 0,05 & 0,73 & 0,20 & 1,30 & 0,04 \\
\hline & 72 & 0,00 & 0,00 & 0,01 & 0,01 & 0,00 & 0,00 & 0,00 & 0,00 & 0,00 & 0,00 \\
\hline
\end{tabular}


Os cultivos em glicose foram feitos com o objetivo de controlar a produção dos polímeros na ausência de um co-substrato. Como é possível observar na tabela 12 , houve apenas a produção de P3HB quando somente a glicose foi fornecida como fonte de carbono, mesmo após 72 horas de cultivo. Nos cultivos que foram acrescidos de ácido após 24horas (tabelas 13,14 e 15), momento em que a amostra foi retirada, também observou-se apenas a presença de P3HB. Esse resultado é esperado, uma vez que até o momento da coleta da amostra, apenas a glicose estava disponível como fonte de carbono. Nas primeiras 24 horas, a célula bacteriana utiliza a glicose preferencialmente para o crescimento, entretanto pode haver o uso da fonte de carbono para o acúmulo de $\mathrm{P} 3 \mathrm{HB}$, o que justifica a produção nas primeiras 24 horas de cultivo (BRAUNEGG; LEFEBVRE; GENSER, 1998).

A linhagem LFM 344 contendo o plasmídeo pBBRMCS-2 abrigando o gene phaC de B. sacchari foi construída com o objetivo de avaliar se a expressão do gene é alterada quando este está presente em um plasmídeo em comparação com a presença do gene integrado ao cromossomo bacteriano (LFM 101).

Após 72 horas de cultivo, foi possível avaliar a produção de polihidroxialcanoatos após a utilização dos ácidos graxos como fonte de carbono. Nos cultivos utilizando ácidos graxos com números de carbono pares, como ácido butírico e ácido octanóico (tabela 13-15) observou-se a produção exclusiva de P3HB em todas as linhagens. Essa dado já foi relatado na literatura, utilizando os mesmos ácidos com a linhagem selvagem (LFM 101), que também foi capaz de acumular apenas P3HB.

A partir das análises feitas no cromatógrafo gasoso (tabela 17), foi possível observar que todos os ácidos foram totalmente consumidos após 72 horas de cultivo em todas as linhagens, o que justifica o aumento do $\mathrm{pH}$ em comparação com o valor de 24 horas .

Os ensaios de acúmulo feitos com o gene phaEC de Thiocapsa pffenigii, nas linhagens LFM 344 e LFM 461, indicaram que esse gene não foi capaz de reestabelecer a capacidade de acúmulo dessas cepas. Visto que a o gene não foi funcional em nenhuma das duas linhagens utilizadas, é possível que haja algum problema na sequência ou estrutura do mesmo.

Após 72 horas de cultivo utilizando ácidos graxos com números ímpares de carbono, foi possível observar a incorporação de monômeros de $3 \mathrm{HV}$. O ácido valérico, que contém 5 carbonos em sua estrutura, é diretamente utilizado como precursor do monômero nas três linhagens testadas (HOLMES, 1985a). Quando o cultivo é alimentado com ácido heptanoico 
também é possível observar a incorporação de monômeros de 3HV, apesar de o ácido conter 7 carbonos em sua estrutura. Isso se justifica pelo fato de que este ácido é metabolizado pela $\beta$ oxidação, que elimina dois átomos de carbono na forma de acetil, o que resulta em um intermediário remanescente de 5 carbonos que poderia ser incorporado ao polímero na forma de 3HV. O mesmo acontece quando utiliza-se o ácido nonanoico que perde 4 carbonos, dois a cada ciclo da $\beta$ oxidação, resultando igualmente em um intermediário de 5 carbonos (BRAUNEGG; LEFEBVRE; GENSER, 1998; HOLMES, 1985A; MENDONÇA, 2009; MENDONÇA et al., 2014; SLATER et al., 1998).

$\mathrm{Na}$ tabela 15, é possível observar que a fração de HV incorporada pela linhagem LFM 344 abrigando phaC de B. sacchari foi de 30,6 mol\%, valor muito aproximado do valor observado na literatura para a linhagem selvagem LFM 101 que é de 28,1 mol\% (MENDONÇA et al., 2014). O mesmo ocorre quando o ácido nonanoico é utilizado, onde a fração de HV da linhagem selvagem (17,92 mol\%) é muito próximo ao valor obtido pela recombinante 344 abrigando phaC de B. sacchari (18,3 mol\%).

Entretanto essa equivalência de valores não é observada em relação ao recombinante LFM 344 abrigando phaC de C. vinosum. A fração de HV incorporado no cultivo contendo ácido heptanoico é de 7,21mol \% e quando o ácido nonanoico é utilizado essa fração é de 2,76 mol\%, valores significantemente menores quando comparado aos controles. Essa queda na fração de HV incorporado, se deve pela atividade da pha sintase de classe III ter sido utilizada nesse recombinante. Esse tipo de PHA sintase tem maior afinidade por monômeros de cadeias carbônicas contendo de 6 a 8 carbonos, e não de 5 como a PHA sintase de classe I presente nos controles (REHM, 2003).

Na tabela 16 pode-se observar que houve a expressão dos genes nos recombinantes de B. sacchari construídos portando a PHA sintase do tipo III oriunda de Allochromatium vinosum ( phaEC $_{C v}$ ), que permitiu que o mutante voltasse a acumular PHA. Quando apenas a glicose é utilizada como fonte de carbono, a $p h a E C_{C v}$ se mostra mais eficiente que a PHA sintase nativa, uma vez que na linhagem recombinante, abrigando o referido gene, observouse um acúmulo de 46,30\% da massa seca celular, e na linhagem selvagem o valor foi de $43,30 \%$ da massa seca celular.

A partir de glicose (tabela 12), recombinantes portando phaEC $C_{v}$ acumularam polímero composto somente de monômeros de 3-hidroxibutirato, e o teor de PHA acumulado atingiu cerca de $50 \%$ da biomassa celular. Esses dados são condizentes com a literatura, que 
demonstram um acúmulo de cerca de $60 \%$ da massa seca celular na linhagem selvagem (MENDONÇA, 2009).

Considerando informações preliminares (BUFFONI, 2006, MENDONCA et al, 2014) com fortes indícios de que o cultivo de glicose juntamente com o ácido hexanóico, sob condições de acúmulo, favorecia a incorporação de $3 \mathrm{HHx}$ à cadeia polimérica, parte dos ensaios foram realizadas na presença do ácido. No presente trabalho quando o ácido hexanoico foi fornecido na fase de acúmulo, a linhagem selvagem produziu um polímero com 0,30 mol\% de 3HHx . Em contrapartida, nas mesma condições de cultivo, na linhagem abrigando $p h a E C_{C v}$ a fração de $3 \mathrm{HHx}$ foi de $1,85 \mathrm{~mol} \%$.

Em estudo realizado para verificar a produção de PHA pelas bactérias púrpuras sulfurosas indicou que a maior parte delas incorpora apenas monômeros de PHB. Entretanto, algumas linhagens como Allochromatium vinosum 161 1, Allochromatium purpuratum BN5500 e Lamprocystis foram capazes de incorporar 3- HV a partir de ácidos com número ímpar de carbono (LIEBERGESELL, 1991). Quando o gene de Allochromatium vinosum D, foi clonado em E. coli apenas 3HB foi produzido (LIEBERGESELL , 1992).

Tendo em vista que a linhagem selvagem da Allochromatium vinosum $\mathrm{D}$, a qual teve seu gene clonado no presente trabalho, foi capaz de incorporar apenas $3 \mathrm{HB}$ quando clonada em E. coli, fica evidente que a fonte de carbono e o arcabouço metabólico da célula são determinantes para a composição do polímero (GOMEZ, 2000b).

$\mathrm{Na}$ literatura (LIEBERGESELL et al., 1993) foi registrada a expressão do gene da phaEC de Allochromatium vinosum em Pseudomonas putida, obteve-se até 14 mol\% de HHx quando se utilizou octanoato como fonte de carbono. Entretanto, quando se utilizou apenas glicose como fonte de carbono a fração de $3 \mathrm{HHx}$ obtida é de $9,11 \mathrm{~mol} \%$. A presença do gene phaC de B. sacchari,que tem afinidade por substratos contendo de 3 a 5 carbonos, aumentou significativamente a fração de HB presente no polímero (tabela 14), de 0 para 67 mol\% (REHM, 2003).

Ao que parece, o gene phaEC de Allochromatium vinosum tornou a linhagem LFM 461 capaz de incorporar monômeros de $3 \mathrm{HN}$, o que não ocorreu nos controles. Quando a mesma cepa foi testada com o gene da Thiocapsa pffenigii o valor alcançado foi de 47,3mol $\%$ utilizando-se a mesma fonte de carbono. Vale ressaltar que apesar de ter menor capacidade de incorporar 3HHX, quando comparada com outras linhagens, a B. sacchari se destaca pelo seu rápido crescimento em sacarose, e vários estudos estão sendo feitos no sentido de 
melhorar sua capacidade de utilizar xilose e hidrolisado de bagaço de cana de açúcar (LOPES, 2009; LOPES et al., 2009; MENDONÇA, 2009). 


\section{CONCLUSÕES}

- A biblioteca metagenômica, apesar de constituir uma rica fonte de novos genes, possui diversas limitações. Entre elas, estão as técnicas de detecção dos genes que necessitam de rigorosa padronização e verificação previa da eficiência, bem como o fato de que muitas vezes os genes mesmo quando detectados, não estão necessariamente clonados com sua estrutura integral em razão da técnica de montagem da biblioteca.

Entre os recombinantes obtidos nesse trabalho observou-se que:

- Os genes phaEC de Thiocapsa pffenigii não foram capazes de restaurar a capacidade de produzir PHA nos mutantes de B. sacchari e Pseudomonas sp afetados no gene codificador de sua PHA sintase nativa

- O recombinante de B. sacchari abrigando os genes phaEC de Allochromatium vinosum quando submetido as fonte de carbono glicose e hexanoato produziu um polímero com conteúdo de $3 \mathrm{HV}$ inferior ao da linhagem selvagem

- B.sacchari portando os genes phaEC de Allochromatium vinosum, na presença de ácido hexanoico, gerou um polímero contendo uma fração de $3 \mathrm{HHx}$ três vezes maior do que aquela observada no polímero produzido pela a linhagem selvagem.

- O recombinante de Pseudomonas sp abrigando o gene phaEC de Allochromatium vinosum, quando utilizado glicose como fonte de carbono aumentou a capacidade da linhagem LFM 461 de incorporar monômeros 3HHx em relação a linhagem selvagem 046

Essas linhagens poderão ser empregadas na produção de PHA com composição variada, controlando-se a incorporação de frações $3 H H x$ o que deve refletir nas suas propriedades, ampliando suas possibilidades de aplicação 


\section{REFERÊNCIAS*}

$\mathrm{ABE}, \mathrm{H}$. et al. Biosynthesis from gluconate of a random copolyester consisting of 3hydroxybutyrate and medium-chain-length 3-hydroxyalkanoates by Pseudomonas sp. 61-3. Int. J. Biol. Macromol., v. 16, n. 3, p. 115-119, 1994. ISSN 0141-8130.

ANDERSON, A. J.; DAWES, E. A. Occurrence, metabolism, metabolic role, and industrial uses of bacterial polyhydroxyalkanoates. Microbiol. Rev., v. 54, n. 4, p. 450-472, 1990. ISSN 0146-0749.

ANEJA, P. et al. Heterologous complementation of the exopolysaccharide synthesis and carbon utilization phenotypes of Sinorhizobium meliloti Rm1021 polyhydroxyalkanoate synthesis mutants. FEMS. Microbiol. Lett., v. 239, n. 2, p. 277-283, 2004. ISSN 0378-1097.

ANTONIO, R. V.; STEINBÜCHEL, A.; REHM, B. H. Analysis of in vivo substrate specificity of the PHA synthase from Ralstonia eutropha: formation of novel copolyesters in recombinant Escherichia coli. FEMS. Microbiol. Lett., v. 182, n. 1, p. 111-117, Jan. 2000. ISSN 0378-1097.

ATLAS, R. M.; BARTHA, R. Microbial ecology: fundamentals and applications. $4^{\text {th }}$ ed. Menlo Park, CA: Benjamin-Cummings Pub. Co., 1997.

AUSUBEL, F. M. et al. Current protocols in molecular biology. New York: John Wiley \& Sons, 1992.

BOCANEGRA, J. K. et al. Influence of $\mathrm{pH}$ on the molecular weight of Poly-3hydroxybutyric acid (P3HB) produced by recombinant escherichia coli. Appl. Biochem. Biotechnol, May. 2013. ISSN 1559-0291.

BONFIELD, J. K.; STADEN, R. Experiment files and their application during large-scale sequencing projects. DNA Seq., v. 6, n. 2, p. 109-117, 1996. ISSN 1042-5179.

BORNEMAN, J.; TRIPLETT, E. W. Molecular microbial diversity in soils from eastern Amazonia: evidence for unusual microorganisms and microbial population shifts associated with deforestation. Appl. Environ. Microbiol., v. 63, n. 7, p. 2647-253, Jul. 1997. ISSN 0099-2240.

BRAMER, C. O. et al. Polyhydroxyalkanoate-accumulating bacterium isolated from soil of a sugar-cane plantation in Brazil. Int. J. Syst. Evol. Microbiol., v. 51, pt. 5, p. 1709-1713, Sep. 2001. ISSN 1466-5026

\footnotetext{
*De acordo com:

ASSOCIAÇÃO BRASILEIRA DE NORMAS TÉCNICAS. NBR 6023: informação e documentação: referências: elaboração. Rio de Janeiro, 200
} 
BRAUNEGG, G.; LEFEBVRE, G.; GENSER, K. F. Polyhydroxyalkanoates, biopolyesters from renewable resources: physiological and engineering aspects. J. Biotechnol., v. 65, n. 23, p. 127-161, Oct. 1998. ISSN 0168-1656.

BUENO NETO, C. L. et al. Processo para produzir polihidroxialcanoatos a partir de açúcares extraídos da cana-de-açúcar. 1991.

BUFFONI, E. Avaliação da Composição de Polímeros Biodegradáveis Produzidos por Burkholderia sacchari a partir de Diferentes Substratos. 2006. 80 f. Dissertação (Mestrado em Biotecnologia) - Instituto de Pesquisas Tecnológicas do Estado de São Paulo, USP, 2006.

CHEEMA, S. et al. Exploiting metagenomic diversity for novel polyhydroxyalkanoate synthases: production of a terpolymer poly(3-hydroxybutyrate-co-3-hydroxyhexanoate-co-3hydroxyoctanoate) with a recombinant Pseudomonas putida strain. Bioresour. Technol., v. 103, n. 1, p. 322-328, Jan. 2012. ISSN 1873-2976.

CHEN, G. Q. A microbial polyhydroxyalkanoates (PHA) based bio- and materials industry. Chem. Soc. Rev., v. 38, n. 8, p. 2434-2446, Aug. 2009. ISSN 1460-4744.

DIMITROV, M. R. Construção de biblioteca metagenômica e prospecção de genes para a síntese de polihidroxialcanoato. 2009. (Mestrado) - Instituto de Ciências Biomédicas, Universidade de São Paulo, São Paulo, 2009.

FILIPOV, M. C. S. Obtenção e caracterização de mutantes de burkholderia sp. ipt101 deficientes na síntese ou no reconsumo de poli-3-hidroxibutirato - um plástico biodegradável. 2000. 154 f. (Mestrado) - Interunidades em Biotecnologia USP/Instituto Butantan /IPT, Universidade São Paulo, São Paulo, 2000.

GALINDO ROZO, Y. P. Bioprospecção de genes relacionados à biossíntese de polímeros biodegradáveis a partir de uma biblioteca metagenômica de solo de mata atlântica. 2011 . 119 f. (Mestrado) - Interunidades em Biotecnologia USP/IPT/Instituto Butantan, Universidade de São Paulo, São Paulo, 2011.

GILLESPIE, D. E. et al. Isolation of antibiotics turbomycin a and B from a metagenomic library of soil microbial DNA. Appl. Environ. Microbiol., v. 68, n. 9, p. 4301-4306, 2002. ISSN 0099-2240.

GODOY, F. A. et al. Poly-beta-hydroxyalkanoates consumption during degradation of 2,4,6trichlorophenol by Sphingopyxis chilensis S37. Lett. Appl. Microbiol., v. 36, n. 5, p. 315320, 2003. ISSN 0266-8254.

GOMES, R. S. Obtenção de mutantes deficientes no acúmulo de PHA e construção de linhagens recombinantes para o controle da composição monomérica. 2009. (Doutorado) - Instituto de Biotecnologia, Universidade São Paulo, São Paulo, 2009.

GOMEZ, J. G. C. Produção por Pseudomonas sp de polihidroxialcanoatos contendo monômeros de cadeia média a partir de carboidratos: avaliação da eficiência, modificação 
da composição e obtenção de mutantes. 2000a. (Doutorado) - Instituto de Ciências Biomédicas, Universidade de São Paulo, São Paulo, 2000a.

GOMEZ, J. G. C. Produção por Pseudomonas sp de polihidroxialcanoatos contendo monômeros de cadeia média a partir de carboidratos: avaliação da eficiência, modificação da composição e obtenção de mutantes. 2000. (Doutorado) - Instituto de Pesquisas Tecnológicas, Universidade São Paulo, São Paulo, 2000b.

GOMEZ, J. G. C. et al. Evaluation of soil Gram-negative bacteria as regards polyhydroxyalkanoic acids yields from carbohydrates and propionic acid. Appl. Microbiol. Biotechnol., v. 45, p. 785-789, 1996.

GUILLARD, R. R.; RYTHER, J. H. Studies of marine planktonic diatoms. I. Cyclotella nana Hustedt, and Detonula confervacea (cleve) Gran. Can. J. Microbiol., v. 8, p. 229-239, 1962. ISSN 0008-4166.

GUILLARD, R. R. L. Culture of phytoplankton for feeding marine invertebrates. NewYork: Plenum Press, 1962. 26-60 p.

HAI, T.; HEIN, S.; STEINBÜCHEL, A. Multiple evidence for widespread and general occurrence of type-III PHA synthases in cyanobacteria and molecular characterization of the PHA synthases from two thermophilic cyanobacteria: Chlorogloeopsis fritschii PCC 6912 and Synechococcus sp. strain MA19. Microbiology, v. 147, pt. 11, p. 3047-3060, 2001. ISSN $1350-0872$.

HAI, T. et al. Polyhydroxyalkanoate (PHA) accumulation in sulfate-reducing bacteria and identification of a class III PHA synthase (PhaEC) in Desulfococcus multivorans. Appl. Environ. Microbiol., v. 70, n. 8, p. 4440-4448, 2004. ISSN 0099-2240.

HOLMES, P. A. Applications of PHB - a microbially produced biodegradable thermoplastic. Phys. Technology., v. 16, p. 32-36, 1985.

HUISMAN, G. W. et al. Synthesis of poly-3-hydroxyalkanoates is a common feature of fluorescent pseudomonads. Appl. Environ. Microbiol., v. 55, n. 8, p. 1949-1954, 1989. ISSN 0099-2240.

HYAKUTAKE, M. et al. Polyhydroxyalkanoate (PHA) synthesis by class IV PHA synthases employing Ralstonia eutropha PHB(-)4 as host strain. Biosci. Biotechnol. Biochem., v. 75, n. 8, p. 1615-1657, 2011. ISSN 1347-6947.

KIDWELL, J.; VALENTIN, H. E.; DENNIS, D. Regulated expression of the Alcaligenes eutrophus pha biosynthesis genes in Escherichia coli. Appl. Environ. Microbiol., v. 61, n. 4, p. 1391-1398, 1995. ISSN 0099-2240.

KOVACH, M. E. et al. pBBR1MCS: a broad-host-range cloning vector. Biotechniques, v. 16, n. 5, p. 800-802, 1994. ISSN 0736-6205. 
LANGENBACH, S.; REHM, B. H.; STEINBÜCHEL, A. Functional expression of the PHA synthase gene phaC1 from Pseudomonas aeruginosa in Escherichia coli results in poly(3hydroxyalkanoate) synthesis. FEMS. Microbiol. Lett., v. 150, n. 2, p. 303-309, 1997. ISSN 0378-1097.

LEE, I. Y. et al. Improvement of hydroxyvalerate fraction in poly $(\beta$-hydroxybutyrate-co- $\beta$ hydroxyvalerate) by a mutant strain of Alcaligenes eutrophus. J. Ferm. Bioeng, v. 81, p. 255258, 1996.

LEFEVRE, F. et al. Drugs from hidden bugs: their discovery via untapped resources. Res Microbiol, v. 159, n. 3, p. 153-161, 2008. ISSN 0923-2508.

LIEBERGESELL, M.; HUSTCDC, E.; TIMM, A.; STEINBUCHEL, A.; FULLER, R. C.; LENZ, R. W.; AMP, SCHLEGEL. Formation of poly(3-hydroxyalkanoic acids) by phototrophic and chemolithotrophic bacteria. Archives of Microbiology, v. 155, p.415-421 1991.

LIEBERGESELL, M.; MAYER, F.; STEINBÜCHEL, A. Analysis of polyhydroxyalkanoic acid-biosynthesis genes of anoxygenic phototrophic bacteria reveals synthesis of a polyester exhibiting an unusual composition. Applied Microbiology and Biotechnology, v. 40, p. 292300, 1993.

LIEBERGESELL, M.; RAHALKAR, S.; STEINBÜCHEL, A. Analysis of the Thiocapsa pfennigii polyhydroxyalkanoate synthase: subcloning, molecular characterization and generation of hybrid synthases with the corresponding Allochromatium vinosum enzyme. Appl. Microbiol. Biotechnol., v. 54, n. 2, p. 186-194, 2000. ISSN 0175-7598.

LIEBERGESELL M, S. A. Cloning and nucleotide sequences of genes relevant for biosynthesis of poly(3-hydroxybutyric acid) in Chromatiurn vinosum strain D. Eur. J. Riochem., v. 209, p. 135-150, 1992.

LIEBERGESELL, M. et al. Purification and characterization of the poly(hydroxyalkanoic acid) synthase from Allochromatium vinosum and localization of the enzyme at the surface of poly(hydroxyalkanoic acid) granules. Eur. J. Biochem., v. 226, n. 1, p. 71-80, 1994. ISSN 0014-2956.

LOPES, M. S. et al. Role of CcpA in polyhydroxybutyrate biosynthesis in a newly isolated Bacillus sp. MA3.3. J. Mol. Microbiol. Biotechnol., v. 20, n. 2, p. 63-69, 2011. ISSN 16602412.

LOPES, M. S. G. Produção de plásticos Biodegradáveis utilizando hidrolisado hemicelulósico de bagaço de cana-de-açucar. 2009. 131 f. (Doutorado) - Interunidades em Biotecnologia, Universidade São Paulo, São Paulo, 2009.

LOPES, M. S. G. et al. Screening of bacteria to produce polyhydroxyalkanoates from xylose. World Journal Microb. Biotech, v. 25, p. 1751-1756, 2009. 
LORENZ, P.; ECK, J. Metagenomics and industrial applications. Nat. Rev. Microbiol., v. 3, n. 6, p. 510-516, Jun 2005. ISSN 1740-1526.

LORENZ, P. et al. Screening for novel enzymes for biocatalytic processes: accessing the metagenome as a resource of novel functional sequence space. Curr. Opin. Biotechnol., v. 13, n. 6, p. 572-577, Dec. 2002. ISSN 0958-1669.

LÍCIO, D. C. P. Isolamento de bactérias produtoras de polihidroxialcanoatos e caracterização molecular de sua PHA sintase. 2011. 108 f. Dissertação (Mestrado) Interunidades em Biotecnologia, Universidade São Paulo, São Paulo, 2011.

M, S.; N, A.; A., S. Ecological and physiological studies on purple sulphur bacteria (Chromatiaceae) at aswan high dam lake. American-Eurasian Journal Agriculture \& Environmental Science., v. 4, p. 462-467, 2008.

MASSINI, K. C. Bioprospecção de compostos bioativos em uma biblioteca metagenômica. 2004. Dissertação (Mestrado) - Instituto de Ciências Biomédicas, Universidade São Paulo, São Paulo, 2004.

MATSUDA, T. S. Isolamento de bactérias produtoras de Polihidroxialcanoatos de cadeia curta e média a partir de óleos vegetais. 2009. 83 f. Dissertação (Mestrado) - Interunidades em Biotecnologia, Universidade São Paulo, São Paulo, 2009.

MENDONÇA, T. et al. Exploring the potential of Burkholderia sacchari to produce polyhydroxyalkanoates. Applied Microbiology, Submetido.

MENDONÇA, T. T. Isolamento de bactérias produtoras de Polihidroxialcanoatos de cadeia curta e média a partir de óleos vegetais. 2009. 83 f. Dissertação (Mestrado). Microbiologia, Universidade São Paulo, São Paulo, 2009.

MENDONÇA, T. T. et al. Exploring the potential of Burkholderia sacchari to produce polyhydroxyalkanoates. J. Appl. Microbiol., v. 116, n. 4, p. 815-829, Apr. 2014. ISSN 1365 2672.

MIYAKE, M. et al. Control of poly-beta-hydroxybutyrate synthase mediated by acetyl phosphate in cyanobacteria. J. Bacteriol., v. 179, n. 16, p. 5009-5013, Aug. 1997. ISSN 0021-9193.

NODA, I. et al. Preparation and properties of a novel class of polyhydroxyalkanoate copolymers. Biomacromolecules, v. 6, n. 2, p. 580-586, 2005 Mar-Apr 2005. ISSN 15257797.

PANDEY, G. et al. Extracting the hidden features in saline osmotic tolerance in Saccharomyces cerevisiae from DNA microarray data using the self-organizing map: biosynthesis of amino acids. Appl. Microbiol. Biotechnol., v. 75, n. 2, p. 415-426, May 2007. ISSN 0175-7598. 
PARK, S. J. et al. Production of poly(3-hydroxybutyrate-co-3-hydroxyhexanoate) by metabolically engineered Escherichia coli strains. Biomacromolecules, v. 2, n. 1, p. 248-254, 2001. ISSN 1525-7797.

PARK, S. J. et al. Advanced bacterial polyhydroxyalkanoates: towards a versatile and sustainable platform for unnatural tailor-made polyesters. Biotechnol. Adv., v. 30, n. 6, p. 1196-1206, 2012 Nov-Dec 2012. ISSN 1873-1899.

PEREIRA, E. M. Clonagem de genes do ciclo de 2-metilcitrato e avaliação de estratégias para a obtenção de mutantes prp de Burkholderia sacchari, produtora de plástico biodegradável. 2002. Dissertação (Mestrado) - Instituto de Pesquisas Tecnológicas, Universidade São Paulo, São Paulo, 2002.

PEREIRA, E.M. Avaliação da influência de genes do catabolismo de propionato sobre a síntese de copolímero biodegradável em Burkholderia sacchari e outras bactérias. 2007. Tese (Doutorado) - Interunidades em Biotecnologia, Universidade São Paulo, São Paulo, 2007.

PEREIRA, E. M. Diversidade bacteriana de um latos solo sob cultivo intensivo e floresta através da análise metagenômica. 2003. Dissertação (Mestrado) - Faculdade de Ciências Agrárias e Veterinárias, UNESP, Jaboticabal, 2003.

POLI, A. et al. Synthesis, production, and biotechnological applications of exopolysaccharides and polyhydroxyalkanoates by archaea. Archaea, v. 2011, p. 693-695, 2011. ISSN 1472-3654.

PRADELlA, J. G. C. Biopolímeros e intermediários químicos. Relatório técnico no. 84396-205. Centro de Gestão e Estudos Estratégicos, Ciência Tecnologia e Inovação, 2006. Disponível em: 〈http://www.anbio.org.br/pdf/2/tr06_biopolimeros.pdf> Acesso em: 24 set. 2014.

QUILLAGUAMÁN, J. et al. Synthesis and production of polyhydroxyalkanoates by halophiles: current potential and future prospects. Appl. Microbiol.Biotechnol., v. 85, n. 6, p. 1687-1696, Feb 2010. ISSN 1432-0614.

REES, H. C. et al. Detecting cellulase and esterase enzyme activities encoded by novel genes present in environmental DNA libraries. Extremophiles, v. 7, n. 5, p. 415-421, Oct 2003. ISSN 1431-0651.

REHM, B. H. Polyester synthases: natural catalysts for plastics. Biochem. J., v. 376, pt. 1, p. 15-33, Nov 2003. ISSN 1470-8728.

REHM, B. H.; STEINBÜCHEL, A. Biochemical and genetic analysis of PHA synthases and other proteins required for PHA synthesis. Int. J. Biol. Macromol., v. 25, n. 1-3, p. 3-19, 1999 Jun-Jul 1999. ISSN 0141-8130. 
RIIS, V.; MAI, W. Gas chromatography determination of poly-b-hydroxybutyric acid in microbial biomass-esther hydrochloric acid propanolisis. J. Chromatogr., v. 445, p. 285-289, 1988.

RODRIGO, M. P. et al. Molecular characterization of bacterial populations of different soils. Brazilian Journal of Microbiology, v. 37, n. 4, p. 439-447, 2006.

SAMBROOK, J.; FRITSCH, E.; MANIATIS, T. Molecular cloning: a laboratory manual. New York: Cold Spring Harbor Lab. Press, 1989.

SCHALLMEY, M. et al. Harvesting of novel polyhydroxyalkanaote (PHA) synthase encoding genes from a soil metagenome library using phenotypic screening. FEMS. Microbiol. Lett., v. 321, n. 2, p. 150-156, Aug. 2011. ISSN 1574-6968.

SCHLEGEL HG, L. R., KRAUSS I. The isolations of mutants not accumulating poly- $\beta$ hydroxybutyric acid. Arch. Microbiol., v. 71, p. 283-294, 1970.

SHAMALA, T. R. et al. Identification of polyhydroxyalkanoate (PHA)-producing Bacillus spp. using the polymerase chain reaction (PCR). J. Appl. Microbiol., v. 94, n. 3, p. 369-374, 2003. ISSN 1364-5072.

SHEU, D. S.; WANG, Y. T.; LEE, C. Y. Rapid detection of polyhydroxyalkanoateaccumulating bacteria isolated from the environment by colony PCR. Microbiology, v. 146, pt. 8, p. 2019-2025, Aug. 2000. ISSN 1350-0872.

SILVA, L. et al. Freeze-drying of industrial yeast strains:influence of growth conditions, cooling rates and suspending media on the viability of recovered cells. Rev. Microbiol., v. 23, n. 2, p. 117-122, 1992.

SILVA, L. F. et al. Produção biotecnológica de polihidroxialcanoatos para a geração de polímeros biodegradáveis no Brasil. Quím. Nova. v. 30, p. 1732-1743, 2007.

SILVA, L.F. et al. Poly-3-hydroxybutyrate (P3HB) production by bacteria from xylose, glucose and sugarcane bagasse hydrolysate. J. Ind. Microbiol. Biotechnol., v. 31, n. 6, p. 245-254, Jul 2004. ISSN 1367-5435.

SIMON, R.; PRIEFER, U.; PÜHLER, A. A broad host range mobilization system for in vivo genetic engineering: transposon mutagenesis in gram negative bacteria. Nature Biotechnology, v. 1, p. 784-791, 1983.

SIMON-COLIN, C. et al. A novel mcl PHA-producing bacterium, Pseudomonas guezennei sp. nov., isolated from a 'kopara' mat located in Rangiroa, an atoll of French Polynesia. J Appl. Microbiol., v. 104, n. 2, p. 581-586, Feb. 2008. ISSN 1365-2672.

SLATER, S. et al. Multiple beta-ketothiolases mediate poly(beta-hydroxyalkanoate) copolymer synthesis in Ralstonia eutropha. J. Bacteriol., v. 180, n. 8, p. 1979-1987, Apr. 1998. ISSN 0021-9193. 
SOLAIMAN, D. K.; ASHBY, R. D. Rapid genetic characterization of poly(hydroxyalkanoate) synthase and its applications. Biomacromolecules, v. 6, n. 2, p. 5327, 2005. ISSN 1525-7797.

SOLAIMAN, D. K.; ASHBY, R. D.; FOGLIA, T. A. Rapid and specific identification of medium-chain-length polyhydroxyalkanoate synthase gene by polymerase chain reaction. Appl. Microbiol. Biotechnol., v. 53, n. 6, p. 690-694, Jun. 2000. ISSN 0175-7598.

SOLAIMAN, D. K. Y. Polymerase-chain-reaction-based detection of individual polyhydroxyalkanoate synthase phaCl and phac2 genes. Biotech. Lett., v. 24, p. 245-250, 2002.

SPIEKERMANN, P. et al. A sensitive, viable-colony staining method using Nile red for direct screening of bacteria that accumulate polyhydroxyalkanoic acids and other lipid storage compounds. Arch. Microbiol., v. 171, n. 2, p. 73-80, Jan. 1999. ISSN 0302-8933.

STEINBUCHEL, A.; VALENTIN, H. E. DIVERSITY OF BACTERIAL POLYHYDROXYALKANOIC ACIDS. Fems. Microbiology. Letters, v. 128, n. 3, p. 219228, May 1995. ISSN 0378-1097.

STEINBÜCHEL, A. Pohydroxyalkanoic acids. Novel materials from biological sources. Macmillan, 1991.

STEINBÜCHEL, A.; HEIN, S. Biochemical and molecular basis of microbial synthesis of polyhydroxyalkanoates in microorganisms. Adv. Biochem. Eng. Biotechnol., v. 71, p. 81123,2001. ISSN 0724-6145.

SUDESH, K.; ABE, H.; DOI, Y. Synthesis, structure and properties of polyhydroxyalkanoates:biological polyesters. Prog. Polym. Sci, v. 25, p. 1503-1555, 2000.

TARONCHER-OLDENBURG, G.; NISHINA, K.; STEPHANOPOULOS, G. Identification and analysis of the polyhydroxyalkanoate-specific beta-ketothiolase and acetoacetyl coenzyme A reductase genes in the cyanobacterium Synechocystis sp. strain PCC6803. Appl. Environ. Microbiol., v. 66, n. 10, p. 4440-4448, Oct. 2000. ISSN 0099-2240.

TIPPMANN, H.-F. Analysis for free: Comparing programs for sequence analysis. Briefings in Bioinformatics, v. 5, p. 82-87, 2004.

TORSVIK, V. et al. Novel techniques for analysing microbial diversity in natural and perturbed environments. J. Biotechnol., v. 64, n. 1, p. 53-62, Sep. 1998. ISSN 0168-1656.

VALENTIN, H. E. et al. Identification of 4-hydroxyhexanoic acid as anew constituent of biosynthetic polyhydroxyalkanoic acids from bacteria., Appl. Microbiol. Biotechnol., v. 40, n. 5, p. 710-716, 1994.

VALENTIN, H. E.; SCHONEBAUM, A.; STEINBUCHEL, A. Identification of 5hydroxyhexanoic acid,4-hydroxyheptanoic acid and 4-hydroxyoctanoic acid as new 
constituents of bacterial polyhydroxyalkanoic acids. Appl. Microbiol Biotechnol., v. 46, p. 261-267, 1996.

WILD, J.; HRADECNA, Z.; SZYBALSKI, W. Conditionally amplifiable BACs: switching from single-copy to high-copy vectors and genomic clones. Genome Res., v. 12, n. 9, p. 1434-1444, Sep. 2002. ISSN 1088-9051.

ZHENG, L. Z. et al. Molecular cloning and functional analysis of (R)-3-hydroxyacyl-acyl carrier protein:coenzyme A transacylase from Pseudomonas mendocina LZ. FEMS. Microbiol. Lett., v. 252, n. 2, p. 299-307, Nov. 2005. ISSN 0378-1097. 
APÊNDICE - Resultados do sequenciamento

- $\quad$ Clone P5E6

Banda 750 pb - 95\% de similaridade com hypothetical protein de E.coli

CCGCGCGCGATAcGGGTGCCAGGAGAACTGGTTTGCTGGATAAGGCACTGGCCGCGA TTTCTGAGGCTTCTTTACCGCTAATTTCTTGCCGCATCCATTCCCGCGCAGCTTCTGGC GACAGTACCAGTGGGCGGCGGTCATGAATATCTACCAGACCTTGATCTGCCGCAGCA GTGACGATCAAAAATCCTTCGGCTTCGTCACCACGCTCAAATGGTGTGCTACCTATCG CGGCCATAAAAATAGGTTGtCCATCAGCaCGATAGATAAAAAAAGGCTGTTTTTTGTC GCCTTCTTTTTTCCACTCAAACCAGCCATCGGCAAAACAGATTGCCCGACCATGTTGC CAGAGCGGTTTAAACATACGACTGGTTGCCGCAGTTTCTACGCGGGCGTTAATCAGCG GCGGTTT coli

Banda 400pb - 99\% de similaridade com Holo -[acyl-carrier-protein] synthase de $E$.

GTCACGTTAATCTTTCCATCAATATTGCTTCTTCGTAAAGGCTCGAGTTTTTATGCTAA AGATTGCAAGTTGCTTGTAAAAGATAAGTACACTGATCCATAATCGCTGTTGTTGAGG GTGCATGCTGCACAAAATTAAAGTTAAAAAGTAAAACCCCCGTTCCTTACCAGTTCGG GGGTTTTACTTTTTAAAGAGAACGGTATTATTTTTAACTTTCAATAATTACCGTGGCAC AAGCATAGTGCCGCTCATCTGCCAGCGTTACATGCATATTTGCAACGCCCAGCTTTTCC GCCAGTTTTAATGCCTCGCCCCATAGCCGTAGCCGTGATCATATTGCGAA

- Clone P12E3

Banda de 750pb - 99\% de similaridade com Holo -[acyl-carrier-protein] synthase de E. coli

GCTTCTGTGGCATGGTGTAAGCACAGCAATCTTCAATAACGAAGCCAATTTTA ATGTACTTACGAATTGGCGGTCACGTTAATCTTTCCATCAATATTGCTTTCTTCG TAAAGGCTCGAGTTTTTATGCTAAAGATTGCAAGTTGCTTGTAAAAGATAAGT ACACTGATCCATAATCGCTGTTGTTGAGGGTGCATGCTGCACAAAATTAAAGT TAAAAAGTAAAACCCCCGTTCCTTACCAGTTCGGGGGTTTTACTTTTTAAAGAG AACGGTATTATTTTTAACTTTCAATAATTACCGTGGCACAAGCATAGTGCCGCT CATCTGCCAGCGTTACATGCATATTTGCAACGCCCAGCTTTTCCGCCAGTTTTA ATGCCTCGCCCCATAGCCGTAGCCGTGATCATA

Banda de 400pb - 99\% de similaridade com Holo -[acyl-carrier-protein] synthase de E. coli 
CTGTGGCATGGTGTAAGCACAGCAAATCTTCAATAACGAAGCCAATTTTAATG TACTTACGAATTGGCGGTCACGTTAATCTTTCCATCAATATTGCTTTCTTCGTA AAGGCTCGAGTTTTTATGCTAAAGATTGCAAGTTGCTTGTAAAAGATAAGTAC ACTGATCCATAATCGCTGTTGTTGAGGGTGCATGCTGCACAAAATTAAAGTTA AAAAGTAAAACCCCCGTTCCTTACCAGTTCGGGGGTTTTACTTTTTAAAGAGA ACGGTATTATTTTTAACTTTCAATAATTACCGTGGCACAAGCATAGTGCCGCT CATCTGCCAGCGTTACATGCATATTTGCAACGCCCAGCTTTTCCGCCAGTTTT AATGC

- Clone P12G4

Banda de $750 \mathrm{pb}-99 \%$ de similaridade com hypothetical protein de E.coli

CTGGTTTTACATTACCCACCGCGCGCGATACCGGGTGCCAGGAGAACTGGTTTGCTGGAA CACAGCCACTGGCCGCGATTTCTGAGGCTTCTTTACCGCTAATCTCTTGCCGCATCCATTC CCGCGCAGCTTCTGGCGACAGTACCAGTGGGCGGCGGTCATGAATATCTACCAGACCTTG ATCTGCCGCAGCAGTGACGATCAAAAATCCTTCGGCTTCGTCACCACGCTCAAATGGTGT GCTACCTATCGCGGCCATAAAAATAGGTTGTCCATCAGCACGATAGATAAAAAAAGGCT GTTTTTTGTCGCCTTCTTTTTTCCACTCAAACCAGCCATCGGCAAAACAGATTGCCCGACC ATGTTGCCAGAGCGGTTTAAACATACGACTGGTTGCCGCAGTTTCTACGCGGGCGTTAAT CAGCGGCGGTTTATCCCACCATCCGGGAGCATATCCCCAGAAAACCGGATCCAGATGAA GGTGTTCATCACGTTCACTGAGCAGTAGGACTTTGGTTCCCGGCGCGACGTTGTATCTGCC AATGGGTTCGGGATCATAGGGAATATCGCGTTCAATATCTTCCGCGAGAA 